\title{
Geochemical Database for Intrusive Rocks of North-Central and Northeast Nevada
}

Data Series 244

U.S. Department of the Interior

U.S. Geological Survey 
Cover: The granodiorite of Toyn Creek forms prominent outcrops at Harrison Pass, Ruby Mountains, Nevada. 


\section{Geochemical Database for Intrusive Rocks of North-Central and Northeast Nevada}

By Edward A. du Bray, Michael W. Ressel, and Calvin G. Barnes

Data Series 244 


\section{U.S. Department of the Interior DIRK KEMPTHORNE, Secretary}

\section{U.S. Geological Survey \\ Mark D. Myers, Director}

U.S. Geological Survey, Reston, Virginia: 2007

Version 1.0

For sale by U.S. Geological Survey, Information Services

Box 25286, Denver Federal Center

Denver, CO 80225

For more information about the USGS and its products:

Telephone: 1-888-ASK-USGS

World Wide Web: http://www.usgs.gov/

This publication is available online at:

http://pubs.usgs.gov/ds/2007/244

Any use of trade, product, or firm names in this publication is for descriptive purposes only and does not imply endorsement by the U.S. Government.

Although this report is in the public domain, permission must be secured from the individual copyright owners to reproduce any copyrighted materials contained within this report.

Suggested citation:

du Bray, E.A., Ressel, M.W., and Barnes, C.G., 2007, Geochemical database for intrusive rocks of north-central and northeast Nevada: U.S. Geological Survey Data Series 244, 1 CD-ROM . 


\section{Contents}

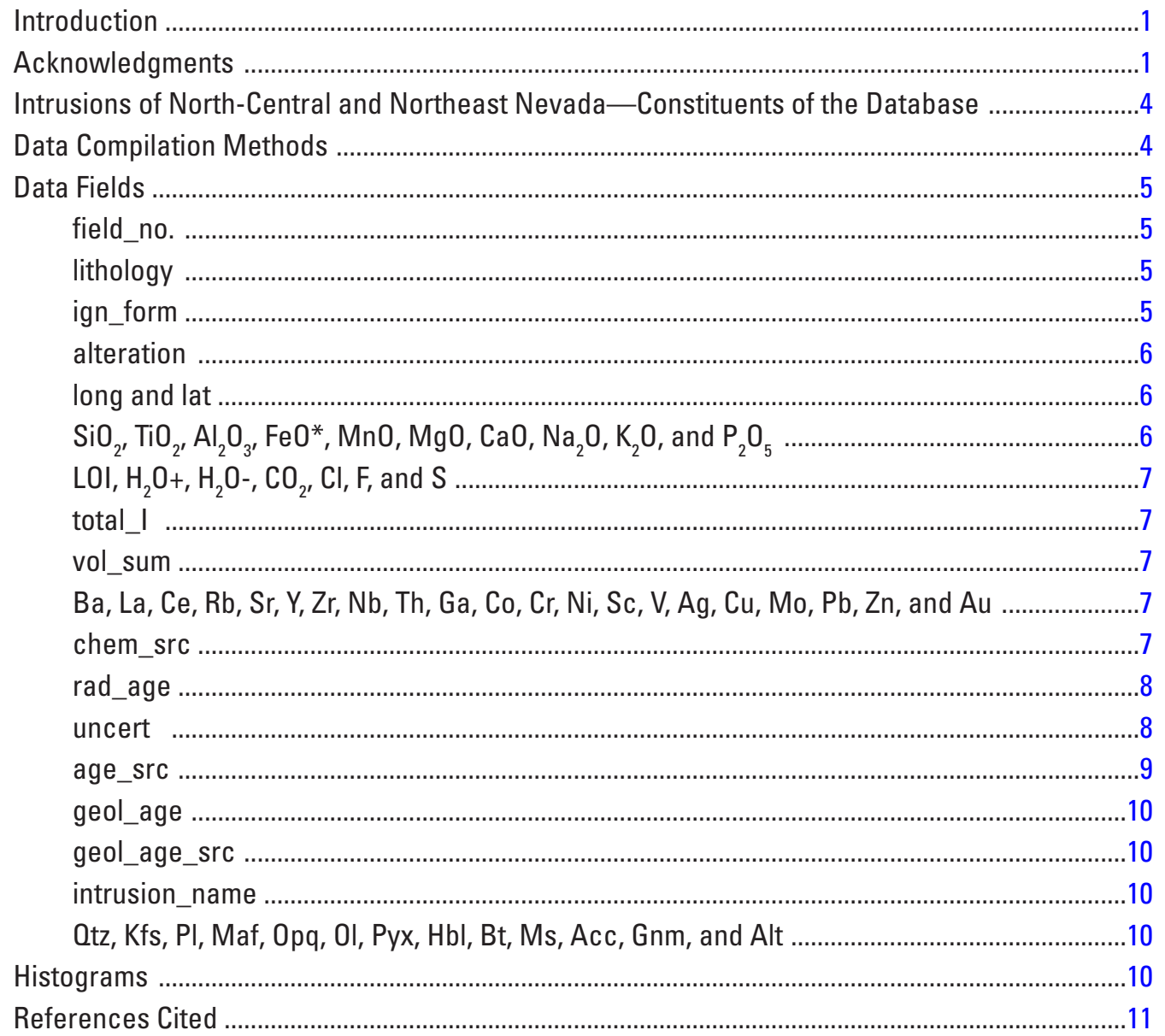

\section{Figures}

1. Index map showing approximate distributions of intrusive rocks in north-central and northeast Nevada

2. Frequency distribution histograms showing compositions of north-central and northeast Nevada intrusive rocks.

\section{Table}

1. Number of observations within each composition range for north-central and northeast Nevada intrusion database 


\title{
Geochemical Database for Intrusive Rocks of North-Central and Northeast Nevada
}

\author{
By Edward A. du Bray, Michael W. Ressel', and Calvin G. Barnes
}

\section{Introduction}

Data presented in this report pertain to the igneous intrusions of north-central and northeast Nevada and were compiled as part of the Metallogeny of the Great Basin project conducted by the U.S. Geological Survey between 2001 and 2007. The geographic area addressed in this compilation is approximately bounded by lats $38.5^{\circ}$ and $42^{\circ} \mathrm{N}$., long $118.5^{\circ}$ W., and the Nevada-Utah border (fig. 1). The area contains numerous large plutons and smaller stocks but also contains many small, shallowly emplaced intrusive bodies, including dikes, sills, and intrusive lava dome complexes. The age, composition, and geographic distribution of intrusions in north-central and northeast Nevada (hereafter, the study area) are summarized by du Bray and Crafford (2007). Intrusive igneous rocks, of multiple ages, are known to be major constituents of the geologic framework in the study area (Stewart and Carlson, 1978). Abundant middle to late Mesozoic and early to middle Cenozoic intrusions in the study area are probably byproducts of subduction-related processes, including back-arc magmatism, that prevailed along the west edge of the North American plate during this interval.

Ressel and others (2000) and Ressel and Henry (2006), for example, have highlighted the association between magmatism and ore deposits along the Carlin trend. Similarly, Theodore (2000) has demonstrated the association between igneous intrusions and ore deposits in the Battle Mountain area.

Decades of geologic investigations in the study area demonstrate that many ore deposits, representing diverse ore deposit types, are spatially, and probably temporally and genetically, associated with igneous intrusions. Because of these associations, studies of many individual igneous intrusions have been completed, including those by a large number of Master's and Doctoral thesis students (particularly University of Nevada at Reno students and associated faculty), economic geologists working on behalf of exploration and mining companies, and U.S. Geological Survey earth scientists. However, despite the

${ }^{1}$ Newmont Mining Corporation

${ }^{2}$ Texas Tech University number and importance of igneous intrusions in the study area, no synthesis of geochemical data available for these rocks has been completed.

Data compilations that are available for igneous intrusions in Nevada pertain to relatively restricted geographic areas and (or), in most cases, do not include the broad array of data that would aid interpretation of these rocks. Smith and others (1971) presented potassium-argon geochronologic and basic petrographic data for a few intrusions in north-central Nevada. Similarly, Silberman and McKee (1971) presented potassium-argon geochronologic data for a significant number of central Nevada intrusions. More recently, Mortenson and others (2000) presented uranium-lead geochronology for a small number of intrusions in the study area. Sloan and others (2003) released a national geochronologic database that contains age determinations made prior to 1991 for rocks of Nevada. Finally, Henry and Sloan (2003) compiled geochronologic data for igneous rocks of Nevada produced subsequent to completion of the Sloan and others (2003) compilation. Consequently, although age data for igneous rocks of Nevada have been compiled, data pertaining to compositional features of these rocks have not been systematically synthesized. Maldonado and others (1988) compiled the distribution and some basic characteristics of intrusive rocks throughout Nevada. Lee (1984), John (1983, 1987, and 1992), John and others (1994), and Ressel (2005) have compiled data that partially characterize igneous intrusions in various parts of Nevada. Contained in the text and data that follow is a more complete synthesis of composition and age data for igneous intrusions of the study area. The ultimate goal of this effort is an evaluation of the time-space-compositional evolution of Mesozoic and Cenozoic magmatism in the study area and identification of genetic associations between magmatism and mineralizing processes in this region.

\section{Acknowledgments}

We would like to thank a number of individuals who helped make this effort possible. The staff of the USGS 

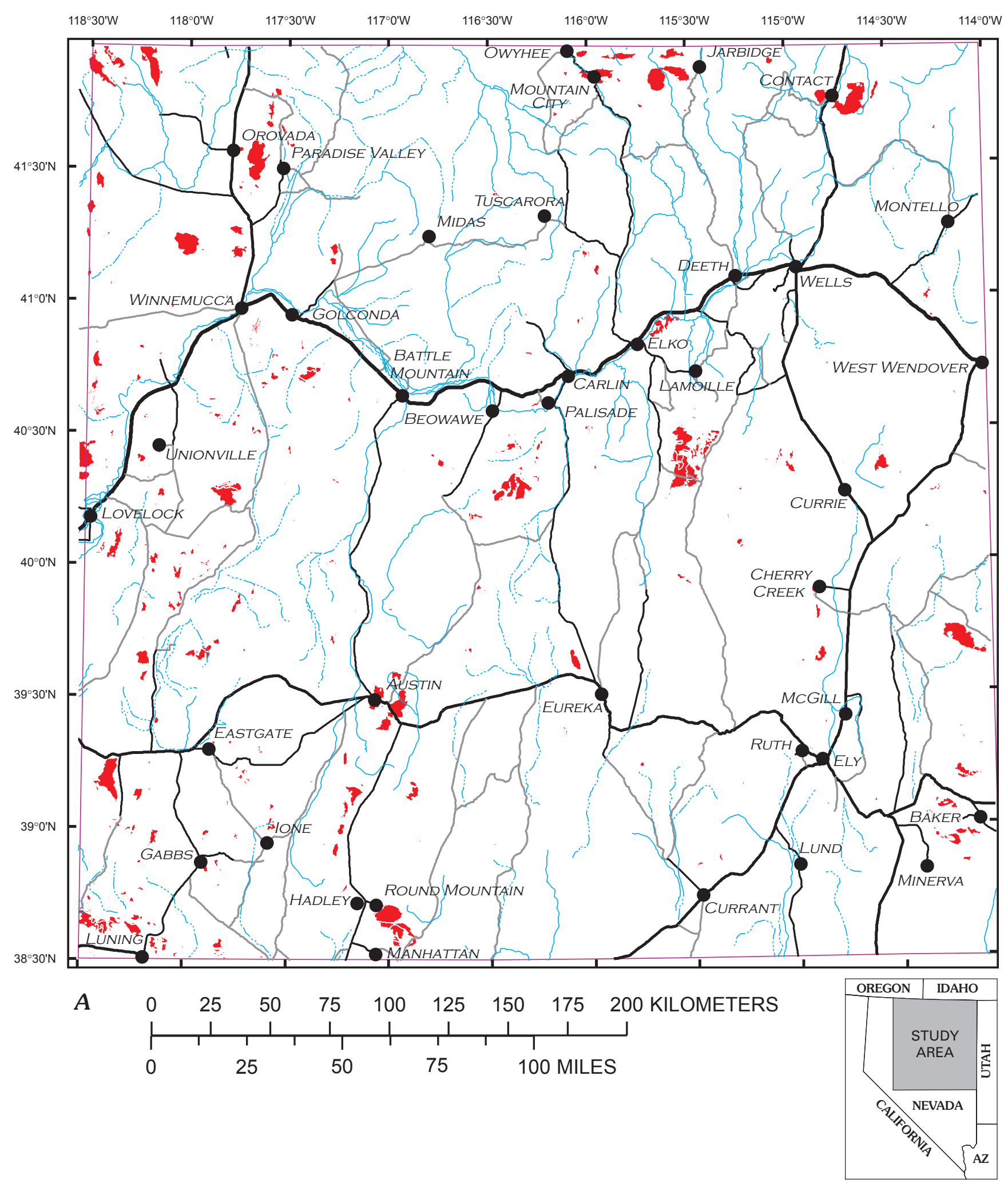

Figure 1 (above and following page). Index map (compiled from Crafford, in press) showing approximate distributions of intrusive rocks and analyzed samples, north-central and northeast Nevada. Thin purple line outlines the Metallogeny of the Great Basin project area (the geographic area within which analyses were compiled). $A$, Locations of intrusions, in red. B, Collection sites for samples included in database, indicated by blue plus symbols. 

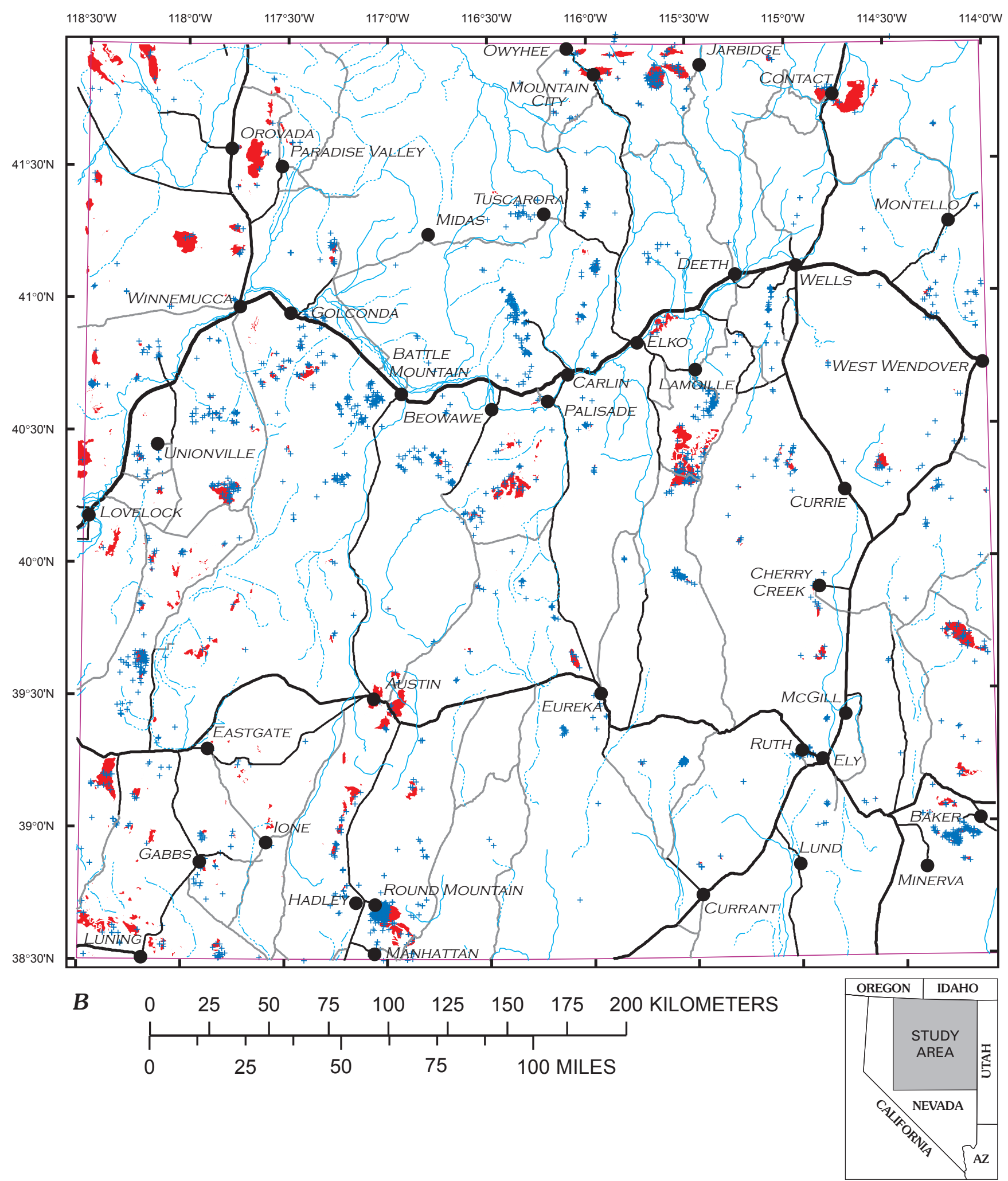

Figure 1. Index map showing approximate distributions of intrusive rocks and analyzed samples, north-central and northeast NevadaContinued. 
Denver library were critical to the success of this compilation. In particular, the library staff used the interlibrary loan process to obtain many of the geologic reports on which this compilation is based. We thank Joan Luce and Frances Vialpando for their tireless typing; data from many sources were available only in analog form and had to be painstakingly typed. Many geologic researchers gave tirelessly of their time to track down missing bits of information that allow this database to be as complete as it is. These individuals include M. Granitto, M.D. Barton, E. Seedorff, J. Nicholes, A.J. McGrew, J.F. Slack, S.W. Nelson, L.J. Garside, S.B. Keith, A.R. Wallace, J.L. Doebrich, D.R. Shawe, R.W. Kistler, E.H. McKee, R.L. Smith, T.G. Theodore, J.M. Hammarstrom, D.A. John, C.S. Rombach, A.W. Snoke, A.T. Strike, K.A. Howard, and S.P. Marsh. In addition we would like to thank Stan Keith (MagmaChem Exploration, Inc), Newmont Mining Corporation, and AngloGold Ashanti for contributing significant amounts of intrusive rock geochemical data. Finally, we gratefully acknowledge technical reviews by D.A. John and C.D. Henry that helped improve this report.

\section{Intrusions of North-Central and Northeast Nevada - Constituents of the Database}

The study area contains numerous large plutons and smaller stocks but also contains many smaller, shallowly emplaced intrusive bodies, including dikes, sills, and intrusive lava dome complexes. Many geologic investigations have demonstrated that intrusions in the study area are principally of three ages, Jurassic, Cretaceous, and Eocene. However, in the western part of the study area, a number of intrusions are thought to be of Triassic age (Johnson, 1977). Several small, shallowly emplaced Miocene-age intrusions have been delineated in various parts of the study area. This report pertains to intrusions of these ages but does not contain data for Paleozoic intrusions, principally very mafic, that are likely parts of detached, allocthonous thrust sheets.

Crafford (in press) recently completed compilation of a digital geologic map of Nevada using the Nevada Bureau of Mines and Geology county reports and accompanying geologic maps as primary sources. The new compilation is based mostly on the existing county maps and generally depicts geologic relations shown on those maps. As part of the digital recompilation, discontinuities across county boundaries were reconciled. The resulting compilation identifies many of the intrusions for which geochemical data were compiled. However, the database also includes data for intrusions, in many cases small intrusions, that were not identified on the county geologic maps. Background documentation for some analytical data presented in this report is incomplete and (or) may be misleading or incorrect, any of which could cause inclusion of inappropriate information in the database. Every effort has been made to preclude inclusion of misleading data; the amount of this type of data inadvertently included in the database is probably small and should not significantly affect data interpretation.

\section{Data Compilation Methods}

Several significant efforts to obtain new compositional data for intrusions in the study area preceded and served as a starting point for the effort documented here. S.B. Keith (MagmaChem Exploration, Inc.) obtained data for samples from several hundred intrusions in the Great Basin. Geologists employed by AngloGold Ashanti collected and analyzed an additional several hundred samples of intrusions in the study area as part of an exploration program. Most recently, as part of Ph.D. thesis research and subsequent investigations, M.W. Ressel collected and analyzed several hundred more samples of intrusions in the study area in an attempt to establish links between various intrusions and Carlin gold deposits.

Copies of original data source materials (subsequently referred to as sources), including published reports and Master's and Doctoral theses, were used to add data to the database. Reference lists contained in sources of data were examined and used to identify additional data sources. In this way, data for about 2,800 samples from 93 sources were identified and incorporated in the database. We believe that this process has probably resulted in identification and incorporation of most of the compositional data that have been produced for samples of intrusions in the study area. In order for a sample to be included in the database, at least a sample number and major oxide analysis were required. Samples for which only trace element data were available were not included in the database. Additional trace element (for instance, the rare earths) and (or) isotopic data are available for some samples, but because the number of these samples is very small, these data were not included in the database. Small amounts of additional data can be gleaned by consulting the appropriate data sources. No effort was made to exclude hydrothermally altered samples from the compilation. Rather, all intrusive rock compositional data were compiled and samples known to be altered were coded accordingly. In a subsequent interpretive phase of this work, additional altered samples will be identified using standard geochemical criteria. The winnowing process will result in two derivative databases. The derivative database for essentially unaltered intrusive rocks will allow evaluation of time-space-composition relations between magmatism and ore genesis. The derivative database containing data for altered rocks will allow evaluation of hydrothermal alteration effects on primary rock compositions. Database users should be wary of samples with $\mathrm{SiO}_{2}$ abundances greater than 77 percent, initial analytic totals less than 95 percent or greater than 103 percent, $\mathrm{Al}_{2} \mathrm{O}_{3}$ abundances less than 10 percent or greater than 20 percent, total volatile contents greater than 5 percent, or $\mathrm{Na}_{2} \mathrm{O} / \mathrm{K}_{2} \mathrm{O}$ ratios less than 1 or greater than about 12 ; samples with any of these characteristics are likely altered and probably do not preserve primary 
igneous rock compositions. Data presented in source materials were included in the database, without modification (with the exception of normalization of major oxide, as described below), and all input subsequently verified.

Data were compiled using Microsoft Excel and can be accessed using software compatible with .xls files. The database release (file, NoNVintrusionGX.xls) includes several worksheets that are accessed using tabs arrayed along the base of the spreadsheet screen display. The tab labeled "Main NV $\mathrm{db}$ " accesses the primary data compilation. The tab labeled "db w censored data deleted" accesses a copy of the primary data compilation in which censored data (data coded as less than some specified value) were deleted prior to calculation of summary statistics and creation of histograms. The tab labeled "no loc" accesses data for samples contained in the U.S. Geological Survey National Geochemical Database for which accurate location data are unavailable. The database release also includes a tab-delimited, text file version of the database (file, NoNVintrusionGX.txt).

\section{Data Fields}

Data fields presented and described below represent those considered most critical to addressing questions concerning the tectonic, petrologic, and metallogenic evolution of magmatism in the study area. Data for each of these fields constitute a column, or set of related columns, in the database. Data in these columns can be sorted, queried, and interpreted to address questions concerning the history, development, and implications of magmatic activity in the study area. Sample number records are aggregated in blocks of data that share a primary geochemical data source.

Blank cells in the database indicate that no data are available for the corresponding column. Some sources report values of zero for some database fields. These values indicate that an abundance determination was attempted but that the constituent was not detected in the sample. Similarly, some sources present qualified data. In particular, records for some samples include less than $(<)$ symbols. These data indicate that the constituent was detected but that its concentration was unquantifiable beyond the fact that its concentration is less than the indicated value. Actual analytical precision (number of significant figures) associated with each database entry is portrayed by each displayed onscreen value. Data in some cells appear to be more precise than displayed values, but this is a misleading artifact of computational processes (for instance, normalization to 100 percent volatile free), which may have been used to create data cell contents. Precision varies within individual columns in accordance with specific analytical protocols and the way data are reported in individual sources. In most cases, the number of significant figures defined in data sources was retained. However, in some cases, the level of precision implied is implausible given either the analytical protocol or the corresponding analytical state of the art; accordingly, some numeric data contained in the database have been rounded to indicate a plausible level of analytical precision.

\section{field_no.}

Identifiers for analyzed samples materials were compiled from sources and presented, without modification.

\section{lithology}

In most cases, a lithologic description of analyzed samples was compiled from information contained in sources. In accordance with procedures defined by the International Union of Geological Sciences, composition names for intrusive rocks are best defined using the relative modal proportions of quartz, alkali feldspar, and plagioclase relative to the classification scheme of Streckeisen (1973). The most informative sources present relative proportions of the feldspars and quartz in text accompanying geologic reports; this information was used to establish composition (or composition range) names for intrusions in the study area. Many publications that serve as sources for our compilation predate the classification recommendations of Streckeisen (1973); most of these used the classification of Johannsen (1931) to define compositions of intrusions in the study area. To the extent possible, and using whatever ancillary data were available, intrusion compositions were converted from the nomenclature of Johannsen (1931) to that of Streckeisen (1973). Most of these transformations were simple and obvious. However, the two nomenclature systems use the term quartz monzonite to define significantly different rocks. Most of the composition field called quartz monzonite by Johannsen (1931) is now referred to as monzogranite in the Streckeisen (1973) system. Not all source authors define which of the two classification schemes was used to categorize intrusion compositions, so some ambiguity persists. An effort was made to recast compositions to the Streckeisen (1973) system in cases for which sufficient data were available to achieve this with confidence that the integrity of primary source data was not compromised.

Many intrusions of the study area are shallowly emplaced and (or) subvolcanic bodies. As such, their grain size precludes petrographic modal analysis and classification using the Streckeisen (1973) system. These rocks are instead treated as volcanic rocks and their composition names were established based on their chemistry and the nomenclature grid described by Le Bas and others (1986).

\section{ign_form}

The form of the igneous intrusion represented by each sample is given where known. Samples coded as representing dikes or sills represent thin tabular bodies that are discordant and concordant with enclosing rocks, respectively. Larger 
intrusive bodies, generally discordant to enclosing rocks, are coded as plutons, stocks, and plugs depending on their size; plutons are the largest of these bodies, whereas plugs are the smallest. In most cases, samples from intrusions coded as plutons represent bodies that cooled slowly, at the greatest depths, and are phaneritic, whereas samples from intrusions coded as plugs represent the subvolcanic environment, many have a quenched groundmass, and some may represent parts of endogenous to exogenous volcanic flow domes.

\section{alteration}

Many sources explicitly indicate that some analyzed samples are altered. Other sources provide sufficient descriptive information about samples that alteration can be inferred. Some sources simply indicate that samples are altered; these samples are simply coded as "Yes" in the "alteration" column. Other alteration terms used to code altered samples include advanced argillic (abbreviated "adv argillic"), phyllic, argillic, propylitic, potassic, skarn, greisen, silicification, oxidation, tourmaline, metamorphic, and deuteric. Each of these terms is applied in accordance with their standard usage, defined for instance by Guilbert and Park (1986). These terms are appended with a "?" when the proper alteration nomenclature is ambiguous due to the nature of available descriptive information.

\section{long and lat}

An effort was made to obtain location data for all samples with composition data. Most sources contain some form of location information. Missing sample location data were requested from authors, most of whom were able to provide missing information. Accordingly, location data are available for all but two samples. Latitude and longitude data are reported as decimal degrees (relative to the 1927 North American Datum). In the study area, longitude is reported as a negative value (western hemisphere) and latitude as a positive value (northern hemisphere).

Location data are of variable quality as a consequence of the manner in which they were initially acquired and subsequently reported. The number of significant figures presented as part of location data in the "long" and "lat" columns defines relative levels of sample location precision, as follows:

- four significant figures indicates that the given location is accurate within 10's of meters,

- three significant figures indicates that the given location is accurate within 100's of meters, and

- two significant figures indicates that the given location is accurate within 1,000's of meters.

Some sources report sample location in terms of Township, Range, and section values, usually to the closest $1 / 4$ of a section. Township-Range-section data were digitized to obtain decimal degree location; within the appropriate 1/4 section quadrilaterals, digitized points were usually selected to coincide with a road, trail, stream bottom, quarry, or natural cliff, any of which might represent a likely sampling location. Some sources do not include numerical sample location data but do contain sample maps. Location data for these samples were obtained by digitizing sample sites. A very few sources merely describe sample locations; these were used to estimate a sample location, which was then digitized.

Some early records contained in the U.S. Geological Survey National Geochemical Database contain location data keyed to quadrangle corners. These location data, and therefore the associated composition data, are of uncertain utility. For the sake of completeness, and in the hope that location data can ultimately be recovered for these samples, composition data for these samples are compiled in a separate worksheet $(\mathrm{tab}=\mathrm{no}$ loc $)$ in the database. Data for these samples are not included in the histograms or the statistical measures.

\section{$\mathrm{SiO}_{2}, \mathrm{TiO}_{2}, \mathrm{Al}_{2} \mathrm{O}_{3^{\prime}}, \mathrm{FeO}$, $\mathrm{MnO}, \mathrm{MgO}, \mathrm{CaO}, \mathrm{Na}_{2} \mathrm{O}$, $\mathrm{K}_{2} \mathrm{O}$, and $\mathrm{P}_{2} \mathrm{O}_{5}$}

Sources report whole rock, major oxide data in a variety of formats. In addition, these data were produced by a wide array of analytical procedures, each with its own associated analytical precision and accuracy. Compositions for many of the samples included in the database are presented in their sources already normalized to 100 percent volatile free. Some information loss occurs when data are reported solely in this fashion. Compiling analytical methods and associated estimates of precision and accuracy associated with the reported data was beyond the scope of this effort. Analytical protocols, precision, and accuracy were highly variable among sources. Fortunately, most sources document these parameters so that associated questions can be resolved by referring to the appropriate data source. The database includes columns for the abundances of $\mathrm{SiO}_{2}, \mathrm{TiO}_{2}, \mathrm{Al}_{2} \mathrm{O}_{3}, \mathrm{FeO}, \mathrm{MnO}, \mathrm{MgO}, \mathrm{CaO}$, $\mathrm{Na}_{2} \mathrm{O}, \mathrm{K}_{2} \mathrm{O}$, and $\mathrm{P}_{2} \mathrm{O}_{5}$. However, because diverse analytical protocols were used to analyze samples, not all sources contain data for each of these constituents.

Several different schemes are possible for reporting iron contents. In addition, reported abundances of ferrous versus ferric iron in many of these rocks are unlikely to represent magmatic values, because of oxidation during late- to postmagmatic hydrothermal alteration. Consequently, total iron abundances were recalculated as ferrous iron oxide and denoted as $\mathrm{FeO}^{*}$. Interaction with postmagmatic fluids caused compositions of many intrusive rocks of the study area to change in other ways as well. In particular, many of these rocks were hydrothermally altered (as indicated by secondary clay minerals, sericite, and (or) chlorite). Both processes caused volatile contents of the affected samples to increase, and correspondingly caused relative abundances of all other constituents to decrease. Therefore, to facilitate meaningful oxide abundance comparisons among samples, all analyses 
were normalized to 100 percent on a volatile-free basis. The resulting data are reported in columns identified by $\mathrm{SiO}_{2}, \mathrm{TiO}_{2}$, $\mathrm{Al}_{2} \mathrm{O}_{3}, \mathrm{FeO}^{*}, \mathrm{MnO}, \mathrm{MgO}, \mathrm{CaO}, \mathrm{Na}_{2} \mathrm{O}, \mathrm{K}_{2} \mathrm{O}$, and $\mathrm{P}_{2} \mathrm{O}_{5}$. All data are reported as weight percent.

\section{$\mathrm{LOI}, \mathrm{H}_{2} \mathrm{O}+, \mathrm{H}_{2} \mathrm{O}-, \mathrm{CO}_{2}, \mathrm{Cl}$, F, and $\mathrm{S}$}

Data sources report volatile constituent contents of samples from intrusions in the study area in widely disparate ways. In order to capture important information concerning the volatile contents of these rocks, an array of data columns was designated to account for various analytical protocols and data reporting formats. Volatile constituents whose abundances are commonly determined include LOI (loss on ignition), $\mathrm{H}_{2} \mathrm{O}+$ (bound), $\mathrm{H}_{2} \mathrm{O}$ - (nonessential, moisture), $\mathrm{CO}_{2}$, $\mathrm{Cl}, \mathrm{F}$, and $\mathrm{S}$. Of these, few sources contain halogen and $\mathrm{S}$ abundance data. Similarly, data for $\mathrm{H}_{2} \mathrm{O}+, \mathrm{H}_{2} \mathrm{O}-$, and $\mathrm{CO}_{2}$ are rarely and nonsystematically reported. However, given the potential importance of these constituents in hydrothermal processes, compiling all available data for these components seems warranted. Several sources present data for $\mathrm{H}_{2} \mathrm{O}$ and do not specify whether this species is bound water $(+)$ or nonessential moisture (-). These data have been included in the $\mathrm{H}_{2} \mathrm{O}+$ column of the database.

\section{total_I}

One measure of major oxide analytical accuracy is how nearly the sum of the determined constituents approaches 100 percent. Consequently, the database includes a column that reports initial analytical totals as reported by the source. Some sources do not include totals; totals for these samples were computed and added to the database. Initial analytical totals reported in the sources were spot checked for accuracy; discrepancies were noted and corrected in a number of cases. Many sources present abundances for the oxides listed above but include no abundance data for volatile constituents. Initial analytical totals for these samples tend to be several to 5 or 6 percent less than 100 percent. Unfortunately, it is impossible to determine whether these low initial totals result from inaccurate analyses and (or) unreported volatile constituent abundances.

\section{vol_sum}

The total volatile content of intrusions in the study area can provide some insight concerning whether abundances of other constituents accurately represent primary magmatic values. Samples with elevated volatile contents, for example greater than 3 weight percent, are likely to have experienced some fluid-mediated, postmagmatic chemical modification. Given the wide range of analytical protocols used in analysis of these samples, the best possible measure of sample volatile content is total volatile content. For the purposes of the compilation, if LOI data are the only information contained in source data compilations concerning volatile content, LOI values were designated as total volatile content. Alternatively, if the source includes data for $\mathrm{H}_{2} \mathrm{O}+, \mathrm{H}_{2} \mathrm{O}-, \mathrm{CO}_{2}, \mathrm{Cl}, \mathrm{F}$, or $\mathrm{S}$, these data were summed to yield total volatile content. All data are presented as weight percent.

\section{$\mathrm{Ba}$, La, Ce, Rb, Sr, Y, Zr, Nb, Th, Ga, Co, Cr, Ni, Sc, $\mathrm{V}, \mathrm{Ag}, \mathrm{Cu}, \mathrm{Mo}, \mathrm{Pb}, \mathrm{Zn}$, and $\mathrm{Au}$}

The sources present data for inconsistent sets of trace elements. Of these, data for $\mathrm{Ba}, \mathrm{La}, \mathrm{Ce}, \mathrm{Rb}, \mathrm{Sr}, \mathrm{Y}, \mathrm{Zr}, \mathrm{Nb}$, Th, Ga, Co, Cr, Ni, Sc, V, Ag, Cu, Mo, Pb, Zn, and Au were compiled; all data are in parts per million. These constituents are among those for which sources most often contain data and also are considered sufficient to address many petrologic, tectonic, and metallogenic questions.

\section{chem_src}

Chemical, petrographic, and location data for each sample included in the database were compiled from primary data sources, in most cases a single source. For a few samples, data were culled from two or more sources; for example, major oxide data may have been compiled from one source and trace element data from another. Most entries in the "chem_src" column of the database are keyed numerically to sources identified in the following list. However, some of these data were compiled from sources principally dedicated to presenting geochronologic data. Alpha-coded entries in the "chem_src" column correspond to sources identified in the "age_src" section of this report. Sources of geochemical information include publications of the U.S. Geological Survey, unpublished data contained in the U.S. Geological Survey National Geochemical Database, Master's theses, Doctoral dissertations, articles published in journals, and publications of the Nevada Bureau of Mines and Geology.

1. Henry and Faulds (1999)

2. Gilluly and Masursky (1965)

3. Erickson and others (1978)

4. Henry and Boden (1998)

5. Henry, C.D., Nevada Bureau of Mines and Geology, unpublished data, 2006

6. Henry and others (1999)

7. Willden (1964)

8. Shaver and Jeanne (1996)

9. Muffler (1964)

10. Gilluly and Gates (1965)

11. Shawe and others (1962)

12. Hotz and Willden (1964)

13. Johnson (1977)

14. Theodore (2000)

15. du Bray, E.A., U.S. Geological Survey, unpublished data, 2006

16. Roberts (1964) 
17. Theodore and others (1973)

18. Theodore and others (1992)

19. Doebrich (1995)

20. Smith and others (1971)

21. Lee and others (1981)

22. Lee and Van Loenen (1971)

23. Barnes and others (2001)

24. Lee and others (2003)

25. Emsbo and others (2003)

26. Lee (1984)

27. Ressel, M.W., Newmont Mining Corporation, unpublished data, 2006

28. Ressel (2005)

29. Seymour (1980)

30. Emmons and Eng (1995)

31. Thole and Prihar (1998)

32. James (1976)

33. Lawson (1906)

34. Bauer and others (1966)

35. Drewes (1967)

36. Spencer (1917)

37. Shawe (1961)

38. Fournier (1967)

39. Phinisey (1995)

40. Evans (1974)

41. Radtke (1985)

42. Nosker (1981)

43. John (1997)

44. Hargrove (1982)

45. Taylor (1982)

46. Pullman (1983)

47. Smith (1981)

48. Henry (1996)

49. McKee (1976a)

50. Ferguson (1924)

51. Knopf (1924)

52. Hague (1892)

53. Clark (1922)

54. Vikre (1985)

55. McGrew, A.J., University of Dayton, unpublished data, 2006

56. Hofstra (1994)

57. Barnes, C.G., Texas Tech University, unpublished data, 2006

58. Boden (1987)

59. John (1992)

60. U.S. Geological Survey, National Geochemical Database, 2006

61. Shawe and Lepry (1985)

62. Starkey (1987)

63. Myers (1994)

64. Merriam and Anderson (1942)

65. Smith and Ketner (1976)

66. Silberman and others (1974)

67. Thurber (1982)

68. Gibbons (1973)
69. Nelson (1975)

70. Kistler and others (1981)

71. Sayeed (1973)

72. Bonham and others (1991)

73. Brooks (1994)

74. Brooks and others (1991)

75. Keith, S.B., MagmaChem Exploration, Inc., unpublished data, 2006

76. Anglo Gold Ashanti, unpublished data, 2006

77. Putney (1985)

78. Clarke (1915)

79. Johnson and Keith (1991)

80. John and others (2000)

81. Ressel and others (2000)

82. Missallati (1973)

83. John, D.A., U.S. Geological Survey, and Henry, C.D., Nevada Bureau of Mines and Geology, unpublished data, 2006

84. John, D.A., U.S. Geological Survey, unpublished data, 2006

85. Wrucke and Silberman (1975)

86. Shawe (2003)

87. Wrucke and Armbrustmacher (1973)

88. Strike (2000)

89. Burton (1997)

90. Lee (1999)

91. Batum (1999)

92. Burling (1996)

93. Jeon (1999)

\section{rad_age}

The ages of the intrusions in the study area have been of keen interest and a large number of age determinations have been made. The database column titled "rad_age" contains geochronologically determined ages, in millions of years, for samples of intrusions in the study area. Multiple geochronologic age determinations (including $\mathrm{U}-\mathrm{Pb}$ zircon, $\mathrm{Ar}-\mathrm{Ar}$, $\mathrm{Rb}-\mathrm{Sr}$, and $\mathrm{K}-\mathrm{Ar}$ ages) have been obtained for some intrusions. A listing of the various geochronologic techniques, arranged in order of decreasing accuracy, is as follows: U-Pb zircon, $\mathrm{Ar}-\mathrm{Ar}, \mathrm{Rb}-\mathrm{Sr}$, and K-Ar. Preferred age estimates recorded in the "rad_age" column reflect this reliability ranking. K-Ar age determinations have been made for both biotite and hornblende mineral separates of some samples. In these cases, age determinations derived from hornblende are included in the database in preference to those for biotite. Fission-track age determinations were not included in the compilation.

\section{uncert}

The database column titled "uncert" contains data, in millions of years, for the analytical uncertainties (as presented in the source) associated with each of the age determinations reported in the "rad_age" column. 


\section{age_src}

Sloan and others (2003) and C.D. Henry (Nevada Bureau of Mines and Geology, unpublished data, 2006) have compiled (and recalculated ages using currently accepted decay constants, as appropriate) most of the isotopic age data available for intrusions in the study area. Their compilations were used to identify the primary data sources (identified in the database column titled "age_src") from which moderately abundant geochronologic data for the intrusions in the study area were extracted to compile ages of samples included in the database. In most cases, geochemical and geochronologic data are contained in the same source; the age source for each of these samples is numerically keyed to a previously identified source of geochemical data (database column "chem_src"). For the relatively small number of samples for which geochemical and geochronologic data have different sources, age source(s) data are keyed to alpha-coded citations listed below:

A. Silberman and McKee (1971)

B. Lee and others (1980)

C. Lee and others (1970)

D. Lee and others (1986)

E. Mortensen and others (2000)

F. Kistler and Lee (1989)

G. Coats and others (1965)

H. McDowell and Kulp (1967)

I. Miller and others (1988)

J. Kelson and others (2000)

K. Farmer (1996)

L. Armstrong (1970a)

M. Ketner (1998)

N. Evans and Ketner (1971)

O. McKee (1992)

P. Doebrich (1994)

Q. Wells and others (1971)

R. Shawe (1999)

S. Mueller (1992)

T. James (1972)

U. Gans and others (1989)

V. Hofstra and others (1999)

W. Ketner (1990)

X. McKee and others (1971)

Y. McKee and Silberman (1970)

Z. Marvin and Cole (1978)

AA. Shawe (1995)

AB. Maher and others (1990)

AC. Tingley (1975)

AD. Carlson and others (1975)

AE. Morabbi (1980)

AF. Armstrong (1966)

AG. Rahl and others (2002)

AH. Morton and others (1977)

AI. Armstrong (1970b)

AJ. Marvin and Dobson (1979)

AK. Maher (1989)

AL. Hudson and others (2000)
AM. Elison and others (1990)

AN. John and Robinson (1989)

AO. Stablein (1969)

AP. Krueger and Schilling (1971)

AQ. Miller and others (1990)

AR. Marvin and others (1989)

AS. Schilling (1965)

AT. Pullman (1984)

AU. John (1983)

AV. McGrew and others (2000)

AW. Ross (1961)

AX. Garside and others (1981)

AY. Bryan (1972)

AZ. Shawe and others (1986)

BA. John (1993)

BB. Coats (1987)

BC. Whitebread (1994)

BD. Gilluly (1967)

BE. Decker (1962)

BF. Coats (1971)

BG. Willden and Speed (1974)

BH. Armstrong and Suppe (1973)

BI. Hose and others (1976)

BJ. Lee and others (1999)

BK. McKee and others (1976)

BL. Nolan and others (1974)

BM. Kleinhampl and Ziony (1984)

BN. Speed and McKee (1976)

BO. Slack (1974)

BP. Coats and McKee (1972)

BQ. Coats and Greene (1984)

BR. Coash (1967)

BS. McKee (1976b)

BT. Ekren and Byers (1985)

BU. Evernden and Kistler (1970)

BV. Miller and others (1987)

BW. Edwards and McLaughlin (1972)

BX. Westra and Riedell (1996)

BY. Moores and others (1968)

BZ. Hart and Carlson (1985)

CA. Speed and Armstrong (1971)

CB. Hardyman and others (1988)

CC. McKee (1968)

CD. Stewart and McKee (1977)

CE. Ressel, M.W., Newmont Mining Corporation, and Henry, C.D., Nevada Bureau of Mines and Geology, unpublished data, 2006

CF. Silberling and John (1989)

CG. Ekren and Byers (1986)

CH. Hope (1972)

CI. O’Neill (1968)

CJ. Wooden and others (1999) 


\section{geol_age}

Radiometric ages have not been determined for most samples included in the database. However, all identified age determinations and geologic and geochronologic reasoning have been used to develop preferred geologic age estimates for most volumetrically significant intrusions in the study area. Geologic ages where given in years are rounded to the nearest million, which seems appropriate given the nature of this compilation. No effort was made to establish geologic ages for samples of dikes, sills, and other volumetrically insignificant intrusions. No entry is recorded in the "geol_age" column when the associated sample has been radiometrically dated.

\section{geol_age_src}

Estimates of geologic age for many of the intrusions in the study area rely upon geologic inference, correlations, and other diverse data sources; these sources are identified in the "geol_age_src" column of the database. Digits left of the "l" symbol identify the principal source used to establish geologic age. These digits are keyed to entries previously identified in either the "chem_src" or "age_src" discussions above. Digits to the right of the "" symbol identify the rationale used to establish geologic age. Entries coded as " 11 " indicate that a correlation of map units figure or some discussion of intrusion age in the source provides the basis for the geologic age assignment. In contrast, entries coded as " 2 " indicate that the radiometric age of sample(s) that are not part of the database, but representative of the same intrusion as sample(s) that are included in the database, was used to establish geologic age.

\section{intrusion_name}

We established a unique geographic name for each phaneritic intrusion delineated on the digital geologic map of Nevada (Crafford, in press); these designations are compiled in the "intrusion_name" column of the database. The sources used to establish intrusion ages and compositions were also consulted for geographic name designation. Intrusion names identified in the sources were adopted in our compilation. The sources did not identify geographic names for all intrusions in the study area. In these cases, a nearby named geographic feature was adopted and assigned as the intrusion name. Assigned geographic intrusion names are not designations in the sense of stratigraphic nomenclature. However, geographic names presented in this compilation are in accord with established stratigraphic nomenclature for intrusions for which either formal or informal stratigraphic nomenclature exists, and to the extent that the sources identified these names.

\section{Qtz, Kfs, PI, Maf, Opq, OI, Pyx, Hbl, Bt, Ms, Acc, Gnm, and Alt}

In addition to their geochemical characteristics, the composition of intrusive rocks can be quantified in terms of the relative abundances of the minerals they contain. This type of characterization, modal analysis, is accomplished by point counting either thin sections using a petrographic microscope or stained slabs using a low magnification binocular microscope. The effort involved in conducting these types of modal analyses is time consuming and difficult, with the consequence that this type of data is rarely collected. However, since modal data are precisely the type of information required to classify the composition of phaneritic intrusive rocks (Streckeisen, 1973), compilation of this type of data, as it was encountered in the literature, seemed warranted. This section of the database contains columns for the relative abundances (summing to about 100 percent) in volume percent of quartz (Qtz), alkali-feldspar (Kfs), plagioclase (Pl), the sum of all mafic minerals, including micas, hornblende, and iron-titanium oxides (Maf), opaque iron-titanium oxide minerals (Opq), olivine $(\mathrm{Ol})$, pyroxene (Pyx), hornblende $(\mathrm{Hbl})$, biotite $(\mathrm{Bt})$, muscovite (Ms), accessory minerals (Acc), groundmass minerals (Gnm), and alteration minerals (Alt). Most of these species are self evident. The common accessory minerals include zircon, titanite, apatite, allanite, and fluorite. Groundmass pertains to typically very finely crystalline, aphanitic, or glassy rock whose mineral identity is not easily decipherable using a microscope. Alteration minerals include epidote, sericite, carbonate minerals, chlorite, clay minerals, zeolite, and anhydrite. All modal data were extracted from the same sources as those containing compiled geochemical data.

\section{Histograms}

A series of histograms (fig. 2) is included in order to provide a basic graphical depiction of the compiled data. These histograms portray frequency distributions for the abundances of each geochemical constituent for which data were compiled. In order to prepare each histogram, a table of data abundance classes (bins) versus frequency within each class was computed (table 1). A set of descriptive statistical abundance parameters, including mean and standard deviation, median, minimum, maximum, and count (number of samples for which abundance data for the particular constituent are available), were computed for each database geochemical constituent and are included on the histograms. For the purpose of constructing the histograms and calculating statistics, all censored (less than) values were deleted. The worksheet tab labeled " $\mathrm{db}$ w censored data deleted" is a copy of the primary database with all censored data deleted. 


\section{References Cited}

Armstrong, R.L., 1966, K-Ar dating using neutron activation for Ar analysis-Granitic plutons of the eastern Great Basin, Nevada and Utah: Geochimica et Cosmochimica Acta, v. 30, p. 565-600.

Armstrong, R.L., 1970a, Geochronology of Tertiary igneous rocks, eastern Basin and Range province, western Utah, eastern Nevada, and vicinity, U.S.A.: Geochimica et Cosmochimica Acta, v. 34, p. 203-232.

Armstrong, R.L., 1970b, K-Ar dating using neutron activation for Ar analysis-Comparison with isotope dilution Ar analyses: Geochimica et Cosmochimica Acta, v. 34, p. 233-236.

Armstrong, R.L., and Suppe, J., 1973, Potassium-argon geochronometry of Mesozoic igneous rocks in Nevada, Utah, and southern California: Geological Society of America Bulletin, v. 84, p. 1375-1391.

Barnes, C.G., Burton, B.R., Burling, T.C., Wright, J.E., and Karlsson, H.R., 2001, Petrology and geochemistry of the Harrison Pass pluton, Ruby Mountains core complex, northeastern Nevada: Journal of Petrology, v. 42, p. 901-929.

Batum, Melissa, 1999, Petrology of late Cretaceous and Cenozoic granitic rocks, East Humboldt Range, northeastern Nevada: Lubbock, Tex., Texas Tech University Master's thesis, $167 \mathrm{p}$.

Bauer, H.L., Jr., Breitrick, R.A., Cooper, J.J., and Anderson, J.A., 1966, Porphyry copper deposits in the Robinson mining district, Nevada, in Titley, S.R., and Hicks, C.L., eds., Geology of the porphyry copper deposits, southwestern North America: Tucson, Ariz., The University of Arizona Press, p. 232-244.

Boden, D.R., 1987, Geology, structure, petrology, and mineralization of the Toquima caldera complex, central Nevada: Palo Alto, Calif., Stanford University Ph.D. dissertation, $285 \mathrm{p}$.

Bonham, H.F., Jr., Desilets, M.O., Garside, L.J., and Hsu, L.C., 1991, Geochemical sampling and characterization of Mesozoic rocks in the Winnemucca $30^{\prime}$ by $60^{\prime}$ quadrangle, Nevada: Nevada Bureau of Mines and Geology, unpublished contract report.

Brooks, J.W., 1994, Petrology and geochemistry of the McCoy gold skarn, Lander County, Nevada: Pullman, Wash., Washington State University Ph.D. thesis, 722 p.
Brooks, J.W., Meinert, L.D., Kuyper, B.A., and Lane, M.L., 1991, Petrology and geochemistry of the McCoy gold skarn, Lander County, Nevada, in Raines, G.L., Lisle, R.W., Schafer, R.W., and Wilkinson, W.H., eds., Geology and ore deposits of the Great Basin Symposium Proceedings: Geological Society of Nevada, p. 419-442.

Bryan, D.P., 1972, The geology and mineralization of the Chalk Mountain and Westgate mining districts, Churchill County, Nevada: Reno, Nev., University of Nevada M.S. thesis, $78 \mathrm{p}$.

Burling, T.C., 1996, Magmatism associated with extension, Harrison Pass Pluton, Ruby Mountains, Nevada: Lubbock, Tex., Texas Tech University Master's thesis, 136 p.

Burton, B.R., 1997, Structural geology and emplacement history of the Harrison Pass pluton, central Ruby Mountains, Elko County, Nevada: Laramie, Wyo., University of Wyoming Ph.D. dissertation, 295 p.

Carlson, J.E., Laird, D.W., Peterson, J.A., Schilling, J.H., Silberman, M.L., and Stewart, J.H., 1975, Preliminary map showing distribution and isotopic ages of Mesozoic and Cenozoic intrusive rocks in Nevada: U.S. Geological Survey Open-File Report 75-499, scale 1:1,000,000.

Clark, C.W., 1922, Geology and ore deposits of the Santa Fe district, Mineral County, Nevada: University of California, Bulletin of the Department of Geology, v. 14, no. 1, 74 p.

Clarke, F.W., 1915, Analyses of rocks and minerals from the laboratory of the U.S. Geological Survey 1880 to 1914 : U.S. Geological Survey Bulletin 591, 376 p.

Coash, J.R., 1967, Geology of the Mount Velma quadrangle, Elko County, Nevada: Nevada Bureau of Mines and Geology Bulletin 68, $21 \mathrm{p}$.

Coats, R.R., 1971, Geologic map of the Owyhee quadrangle, Nevada-Idaho: U.S. Geological Survey Miscellaneous Geologic Investigations Map I-665, scale 1:48,000.

Coats, R.R., 1987, Geology of Elko County, Nevada: Nevada Bureau of Mines and Geology Bulletin 101, 112 p.

Coats, R.R., and Greene, R.C., 1984, Geologic map of the northeast quarter of the Mountain City quadrangle, Elko County, Nevada, and Owyhee County, Idaho: U.S. Geological Survey Open-File Report 84-684, scale 1:24,000.

Coats, R.R., Marvin, R.F., and Stern, T.W., 1965, Reconnaissance of mineral ages of plutons in Elko County, Nevada, and vicinity: U.S. Geological Survey Professional Paper 525-D, p. D11-D15.

Coats, R.R., and McKee, E.H., 1972, Ages of plutons and types of mineralization, northwestern Elko County, Nevada: U.S. Geological Survey Professional Paper 800-C, p. C165-C168. 
Crafford, A.E.J., in press, Nevada State digital geologic map: U.S. Geological Survey Data Series 249.

Decker, R.W., 1962, Geology of the Bull Run quadrangle, Elko County, Nevada: Nevada Bureau of Mines and Geology Bulletin 60, 65 p.

Doebrich, J.L., 1994, Preliminary geologic map of the Galena Canyon 7.5-minute quadrangle, Lander County, Nevada: U.S. Geological Survey Open-File Report 94-664, 14 p.

Doebrich, J.L., 1995, Geology and mineral deposits of the Antler Peak 7.5-minute quadrangle, Lander County, Nevada: Nevada Bureau of Mines and Geology Bulletin 109,44 p.

Drewes, Harald, 1967, Geology of the Connors Pass quadrangle, Schell Creek Range, east-central Nevada: U.S. Geological Survey Professional Paper 557, 93 p.

du Bray, E.A., and Crafford, A.E.J., 2007, Composition and age of intrusions in north-central and northeast Nevada: U.S. Geological Survey Data Series 250, 1 CD-ROM.

Edwards, George, and McLaughlin, W.A., 1972, Shell list No.1; K-Ar and Rb-Sr age determinations of California, Nevada and Utah rocks and minerals: Isochron/West, No. 3 , p. 1-7.

Ekren, E.B., and Byers, F.M., 1985, Geologic map of the Win Wan Flat, Kinkaid NW, Kinkaid, and Indian Head Peak quadrangles, Mineral County, Nevada: U.S. Geological Survey Miscellaneous Investigations Series Map I-1578, scale 1:48,000.

Ekren, E.B., and Byers, F.M., 1986, Geologic map of the Mount Annie NE, Mount Annie, Ramsey Spring, and Mount Annie SE quadrangles, Mineral and Nye Counties, Nevada: U.S. Geological Survey Miscellaneous Investigations Series Map I-1579, scale 1:48,000.

Elison, M.W., Speed, R.C., and Kistler, R.W., 1990, Geologic and isotopic constraints on the crustal structure of the northern Great Basin: Geological Society of America Bulletin, v. 102, p. 1077-1092.

Emmons, D.L., and Eng, T.L., 1995, Geologic map of the McCoy mining district, Lander County, Nevada: Nevada Bureau of Mines and Geology Map 103, scale 1:12,000, 12 p.

Emsbo, Poul, Hofstra, A.H., Lauha, E.A., Griffin, G.L., and Hutchinson, R.W., 2003, Origin of high-grade gold ore, source of ore fluid components, and genesis of the Meikle and neighboring Carlin-type deposits, northern Carlin trend, Nevada: Economic Geology, v. 98, p. 1069-1105.
Erickson, R.L., Silberman, M.L., and Marsh, S.P., 1978, Age and composition of igneous rocks, Edna Mountain quadrangle, Humboldt County, Nevada: U.S. Geological Survey Journal of Research, v. 6, no. 6, p. 727-743.

Evans, J.G., 1974, Geology of the Rodeo Creek NE and Welches Canyon quadrangles, Eureka County, Nevada: U.S. Geological Survey Bulletin 1173, 81 p.

Evans, J.G., and Ketner, K.B., 1971, Geologic map of the Swales Mountain quadrangle and part of the Adobe Summit quadrangle, Elko County, Nevada: U.S. Geological Survey Miscellaneous Geologic Investigations Map I-667, scale $1: 24,000$.

Evernden, J.F., and Kistler, R.W., 1970, Chronology of emplacement of Mesozoic batholithic complexes in California and western Nevada: U.S. Geological Survey Professional Paper 623, 42 p.

Farmer, M., 1996, An intrusive study of the Bluestar subdistrict: Denver, Colo., Newmont Gold Company, internal report, $33 \mathrm{p}$.

Ferguson, H.G., 1924, Geology and ore deposits of the Manhattan district, Nevada: U.S. Geological Survey Bulletin $723,163 \mathrm{p}$.

Fournier, R.O., 1967, The porphyry copper deposit exposed in the Liberty open-pit mine near Ely, Nevada; Part II; The formation of hydrothermal alteration zones: Economic Geology, v. 62, p. 207-227.

Gans, P.B., Mahood, G.A., and Schermer, E., 1989, Synextensional magmatism in the Basin and Range Province; A case study from the eastern Great Basin: Geological Society of America Special Paper 233, 53 p.

Garside, L.J., Bonham, H.F., Jr., Ashley, R.P., Silberman, M.L., and McKee, E.H., 1981, Radiometric ages of volcanic and plutonic rocks and hydrothermal mineralization in Nevada-Determinations run under the USGS-NBMG Cooperative Program: Isochron/West, no. 30, p. 11-19.

Gibbons, J.A., 1973, The geology of part of the Contact mining district, Elko County, Nevada: Reno, Nev., University of Nevada M.S. thesis 181 p.

Gilluly, James, 1967, Geologic map of the Winnemucca quadrangle, Pershing and Humboldt Counties, Nevada: U.S. Geological Survey Geologic Quadrangle Map GQ-656, scale 1:62,500.

Gilluly, James, and Gates, Olcott, 1965, Tectonic and igneous geology of the northern Shoshone Range, Nevada: U.S. Geological Survey Professional Paper 465, 153 p. 
Gilluly, James, and Masursky, Harold, 1965, Geology of the Cortez quadrangle, Nevada, with a section on Gravity and aeromagnetic surveys by D.R. Mabey: U.S. Geological Survey Bulletin 1175, 117 p.

Guilbert, J.M., and Park, C.F., Jr., 1986, The geology of ore deposits: New York, W.H. Freeman and Company, 985 p.

Hague, Arnold, 1892, Geology of the Eureka district, Nevada: U.S. Geological Survey Monograph 20, 419 p.

Hardyman, R.F., Brooks, W.E., Blaskowski, M.J., Barton, H.N., Ponce, D.A., and Olson, J.E., 1988, Mineral resources of the Clan Alpine Mountains Wilderness Study Area, Churchill County, Nevada: U.S. Geological Survey Bulletin 1727-B, 16 p.

Hargrove, H.R., 1982, Geology of the southern portion of the Montana Mountains, McDermitt caldera, Nevada: Tempe, Ariz., Arizona State University M.S. thesis, 202 p.

Hart, W.K., and Carlson, R.W., 1985, Distribution and geochronology of Steens Mountain-type basalt from the northwestern Great Basin: Isochron/West, no. 43, p. 5-10.

Henry, C.D., 1996, Geologic map of the Bell Canyon quadrangle, western Nevada: Nevada Bureau of Mines and Geology Field Studies Map 11, scale 1:24,000.

Henry, C.D., and Boden, D.R., 1998, Geologic map of the Mount Blitzen quadrangle, Elko County, northeastern Nevada: Nevada Bureau of Mines and Geology Map 110, scale $1: 24,000,20 \mathrm{p}$.

Henry, C.D., Boden, D.R., and Castor, S.C., 1999, Geologic map of the Tuscarora quadrangle, Nevada: Nevada Bureau of Mines and Geology Map 116, scale 1:24,000, 20 p.

Henry, C.D., and Faulds, J.E., 1999, Geologic map of the Emigrant Pass quadrangle, Nevada: Nevada Bureau of Mines and Geology Open-File Report 99-9, scale 1:24,000.

Henry, C.D., and Sloan, J., 2003, Isotopic age database for the Great Basin and adjacent regions: Nevada Bureau of Mines and Geology, available at URL http://mapserver.library. unr.edu/website/dataworksweb/NevadaRocks/viewer.htm (accessed July 2006).

Hofstra, A.H., 1994, Geology and genesis of Carlin-type gold deposits in the Jerritt Canyon district, Nevada: Boulder, Colo., University of Colorado Ph.D. thesis, 287 p.

Hofstra, A.H., Snee, L.W., Rye, R.O., Folger, H.W., Phinesey, J.D., Loranger, R.J., Dahl, A.R., Naeser, C.W., Stein, H.J., and Lewchuk, M., 1999, Age constraints on Jerritt Canyon and other Carlin-type gold deposits in the western United States-Relationship to mid-Tertiary extension and magmatism: Economic Geology, v. 94, no. 6, p. 769-794.
Hope, R.A., 1972, Geologic map of the Spruce Mountain quadrangle, Elko County, Nevada: U.S. Geological Survey Geologic Quadrangle Map GQ-942, scale 1:62,500.

Hose, R.K., Blake, M.C., Jr., and Smith, R.M., 1976, Geology and mineral resources of White Pine County, Nevada: Nevada Bureau of Mines and Geology Bulletin 85, 105 p.

Hotz, P.E., and Willden, Ronald, 1964, Geology and mineral deposits of the Osgood Mountains quadrangle, Humboldt County, Nevada: U.S. Geological Survey Professional Paper 431, 128 p.

Hudson, M.R., John, D.A., Conrad, J.E., and McKee, E.H., 2000, Style and age of late Oligocene-early Miocene deformation in the southern Stillwater Range, west-central Nevada-Paleomagnetism, geochronology, and field relations: Journal of Geophysical Research, v. 105, p. 929-954.

James, L.P., 1972, Zoned hydrothermal alteration and ore deposits in sedimentary rocks near mineralized intrusions, Ely area, Nevada: University Park, Pa., Pennsylvania State University Ph.D. thesis, 280 p.

James, L.P., 1976, Zoned alteration in limestone at porphyry copper deposits, Ely, Nevada: Economic Geology, v. 71, p. $488-512$.

Jeon, Mi-Ae, 1999, Petrology and stable isotope study of metamorphic and granitic rocks in Lamoille Canyon, Ruby Mountains, Nevada: Lubbock, Tex., Texas Tech University Master's thesis, $151 \mathrm{p}$.

Johannsen, A., 1931, A descriptive petrography of the igneous rocks, v. 1: Chicago, University of Chicago Press, 267 p.

John, D.A., 1983, Map showing distribution, ages, and petrographic characteristics of Mesozoic plutonic rocks in the Walker Lake $1^{\circ}$ by $2^{\circ}$ quadrangle, California and Nevada: U.S. Geological Survey Miscellaneous Field Studies Map MF-1382-B, scale 1:250,000.

John, D.A., 1987, Map showing the distribution and characteristics of plutonic rocks in the Tonopah $1^{\circ}$ by $2^{\circ}$ quadrangle, central Nevada: U.S. Geological Survey Miscellaneous Field Studies Map MF-1877-J, scale 1:250,000.

John, D.A., 1992, Chemical analyses of granitic rocks in the Reno $1^{\circ}$ by $2^{\circ}$ quadrangle and in the northern Pine Nut Mountains, west-central Nevada: U.S. Geological Survey Open-File Report 92-246, 35 p.

John, D.A., 1993, Geologic map of the Job Peak quadrangle, Nevada: Nevada Bureau of Mines and Geology Field Studies Map 5, scale 1:24,000.

John, D.A., 1997, Geologic map of the Wonder Mountain quadrangle, Nevada: Nevada Bureau of Mines and Geology Map 109, scale 1:24,000. 
John, D.A., and Robinson, A.C., 1989, Rb-Sr whole-rock isotopic ages of granitic plutons in the western part of the Tonopah $1^{\circ}$ by $2^{\circ}$ quadrangle, Nevada: Isochron/West, v. 53 , p. 20-27.

John, D.A., Schweickert, R.A., and Robinson, A.C., 1994, Granitic rocks in the Triassic-Jurassic magmatic arc of western Nevada and eastern California: U.S. Geological Survey Open-File Report 94-148, 61 p.

John, D.A., Wallace, A.R., Ponce, D.A., Fleck, R.B., and Conrad, J.E., 2000, New perspectives on the geology and origin of the northern Nevada rift in Cluer, J.K., and others, Geology and ore deposits 2000: Geological Society of Nevada, The Great Basin and Beyond Symposium, May 15-18, 2000, Proceedings, p. 127-154.

Johnson, M.G., 1977, Geology and mineral deposits of Pershing County, Nevada: Nevada Bureau of Mines and Geology, Bulletin 89, 115 p.

Johnson, V.Y., and Keith, J.D., 1991, Petrology and geochemistry of the Springer scheelite skarn deposit, Mill City, Nevada, in Raines, G.L., Lisle, R.W., Schafer, R.W., and Wilkinson, W.H., eds., Geology and ore deposits of the Great Basin, Symposium Proceedings: Geological Society of Nevada, p. 553-578.

Kelson, C.R., Crowe, D.E., and Stein, H.J., 2005, Geochronology and geochemistry of the Hilltop, Lewis, and Bullion mining districts, Battle Mountain-Eureka trend, NevadaWindow to the World: Geological Society of Nevada, Symposium 2005, Program with Abstracts, p. 59.

Ketner, K.B., 1990, Geologic map of the Elko Hills, Elko County, Nevada: U.S. Geological Survey Miscellaneous Geologic Investigations Series Map I-2082, scale 1:24,000.

Ketner, K.B., 1998, Geologic map of the southern Independence Mountains, Elko County, Nevada: U.S. Geological Survey Miscellaneous Geologic Investigations Series Map I-2629, scale, 1:24,000.

Kistler, R.W., Ghent, E.D., and O’Neil, J.R., 1981, Petrogenesis of garnet two-mica granites in the Ruby Mountains, Nevada: Journal of Geophysical Research, v. 86, no. B11, p. 10,591-10,606.

Kistler, R.W., and Lee, D.E., 1989, Rubidium, strontium, and strontium isotopic data for a suite of granitoid rocks from the Basin and Range province, Arizona, California, Nevada, and Utah: U.S. Geological Survey Open-File Report 89-199, 13 p.

Kleinhampl, F.J., and Ziony, J.I., 1984, Mineral resources of northern Nye County, Nevada: Nevada Bureau of Mines and Geology Bulletin 99-B, 243 p.
Knopf, Adolph, 1924, Geology and ore deposits of the Rochester district, Nevada: U.S. Geological Survey Bulletin 762, $78 \mathrm{p}$.

Krueger, H.W., and Schilling, J.H., 1971, Geochron/Nevada Bureau of Mines K-Ar age determinations-List 1: Isochron/West, no. 1, p. 9-14.

Lawson, A.C., 1906, The copper deposits of the Robinson mining district: Berkeley, Calif., University of California, Bulletin of the Department of Geology, v. 4, no. 14, p. 287-357.

Le Bas, M.J., Le Maitre, R.W., Streckeisen, A., and Zanettin, B., 1986, A chemical classification of volcanic rocks using the total alkali-silica diagram: Journal of Petrology, v. 27, p. 745-750.

Lee, D.E., 1984, Analytical data for a suite of granitoid rocks from the Basin and Range Province: U.S. Geological Survey Bulletin 1602, 54 p.

Lee, D.E., Kistler, R.W., Friedman, I., and Van Loenen, R.E., 1981, Two-mica granites of northeastern Nevada: Journal of Geophysical Research, v. 86, p. 10,607-10,616.

Lee, D.E., Kistler, R.W., and Robinson, A.C., 1986, The strontium isotope composition of granitoid rocks of the southern Snake Range, Nevada: U.S. Geological Survey Bulletin 1622, chapter P, p. 171-179.

Lee, D.E., Marvin, R.F., and Mehnert, H.H., 1980, A radiometric study of Mesozoic-Cenozoic metamorphism in eastern White Pine County, Nevada, and nearby Utah: U.S. Geological Survey Professional Paper 1158-C, p. 17-28.

Lee, D.E., Marvin, R.F., Stern, T.W., and Peterman, Z.E., 1970, Modification of potassium-argon ages by Tertiary thrusting in the Snake Range, White Pine County, Nevada: U.S. Geological Survey Professional Paper 700-D, p. D92-D102.

Lee, D.E., and Van Loenen, R.E., 1971, Hybrid granitoid rocks of the southern Snake Range, Nevada: U.S. Geological Survey Professional Paper 668, 48 p.

Lee, J., Gans, P.B., and Miller, E.L., 1999, Geologic map of the Third Butte East quadrangle, Nevada: Nevada Bureau of Mines and Geology Field Studies Map 16, scale $1: 24,000$.

Lee, Sang-Yun, 1999, Geology and petrology of Cretaceous and Tertiary granitic rocks, Lamoille Canyon, Ruby Mountains, Nevada: Lubbock, Tex., Texas Tech University Ph.D. thesis, $272 \mathrm{p}$. 
Lee, Sang-Yun, Barnes, C.G., Snoke, A.W., Howard, K.A., and Frost, C.D., 2003, Petrogenesis of Mesozoic, peraluminous granites in the Lamoille Canyon area, Ruby Mountains, Nevada, U.S.A.: Journal of Petrology, v. 44, p. 713-732.

Maher, B.J., Browne, Q.J., and McKee, E.H., 1990, Chronology of Tertiary igneous and hydrothermal events, Roberts Mountains, Eureka County, Nevada [abs.], in Geology and ore deposits of the Great Basin: Geological Society of Nevada, Program with Abstracts, p. 48.

Maher, K.A., 1989, Geology of the Jackson Mountains, northwest Nevada: Pasadena, Calif., California Institute of Technology Ph.D. dissertation, 526 p.

Maldonado, Florian, Spengler, R.W., Hanna, W.F., and Dixon, G.L., 1988, Index of granitic rock masses in the State of Nevada: U.S. Geological Survey Bulletin 1831, 81 p.

Marvin, R.F., and Cole, J.C., 1978, Radiometric ages; Compilation A, U. S. Geological Survey: Isochron/West, no. 22, p. 3-14.

Marvin, R.F., and Dobson, S.W., 1979, Radiometric ages; Compilation B, U.S. Geological Survey: Isochron/West, no. 26, p. 3-32.

Marvin, R.F., Mehnert, H.H., and Naeser, C.W., 1989, U.S. Geological Survey radiometric ages; Compilation C, Part 3-California and Nevada: Isochron/West, v. 52, p. 3-11.

McDowell, F.W., and Kulp, J.L., 1967, Age of intrusions and ore deposition in the Robinson mining district of Nevada: Economic Geology, v. 62, p. 905-909.

McGrew, A.J., Peters, M.T., and Wright, J.E., 2000, Thermobarometric constraints on the tectonothermal evolution of the East Humboldt Range metamorphic core complex, Nevada: Geological Society of America Bulletin, v. 112, p. 45-60.

McKee, E.H., 1968, Geologic map of the Ackerman Canyon quadrangle, Lander and Eureka Counties, Nevada: U.S. Geological Survey Geologic Quadrangle Map GQ-761, scale 1:62,500.

McKee, E.H., 1976a, Geology of the northern part of the Toquima Range, Lander, Eureka, and Nye Counties, Nevada: U.S. Geological Survey Professional Paper 931, $49 \mathrm{p}$.

McKee, E.H., 1976b, Geologic map of the Austin quadrangle, Lander County, Nevada: U.S. Geological Survey Geologic Quadrangle Map GQ-1307, scale 1:62,500.
McKee, E.H., 1992, Potassium argon and ${ }^{40} \mathrm{Ar} /{ }^{39} \mathrm{Ar}$ geochronology of selected plutons in the Buckingham area, in Theodore, T.G., Blake, D.W., Loucks, T.A., and Johnson, C.A., Geology of the Buckingham stockwork molybdenum deposit and surrounding area, Lander County, Nevada: U.S. Geological Survey Professional Paper 798-D, p. D36-D40.

McKee, E.H., and Silberman, M.L., 1970, Geochronology of Tertiary igneous rocks in central Nevada: Geological Society of America Bulletin, v. 81, p. 2317-2328.

McKee, E.H., Silberman, M.L., Marvin, R.F., and Obradovich, J.D., 1971, A summary of radiometric ages of Tertiary volcanic rocks in Nevada and eastern California; Part I, central Nevada: Isochron/West, no. 2, p. 21-42.

McKee, E.H., Tarshis, A.L., and Marvin, R.F., 1976, Summary of radiometric ages of Tertiary volcanic and selected plutonic rocks in Nevada, Part V-Northeastern Nevada: Isochron/West, no. 16, p. 15-27.

Merriam, C.W., and Anderson, C.A., 1942, Reconnaissance survey of the Roberts Mountains, Nevada: Geological Society of America Bulletin, v. 53, p. 1675-1728.

Miller, D.M., Hillhouse, W.C., Zartman, R.E., and Lanphere, M.A., 1987, Geochronology of intrusive and metamorphic rocks in the Pilot Range, Utah and Nevada, and comparison with regional patterns [Bethridge Creek and Pilot Creek areas]: Geological Society of America Bulletin, v. 99, p. 866-879.

Miller, D.M., Nakata, J.K., and Glick, L.L., 1990, K-Ar ages of Jurassic to Tertiary plutonic and metamorphic rocks, northwestern Utah and northeastern Nevada: U.S. Geological Survey Bulletin 1906, 18 p.

Miller, E.L., Gans, P.B., Wright, J.E., and Sutter, J.F., 1988, Metamorphic history of the east-central Basin and Range Province; tectonic setting and relationship to magmatism, in Ernst, W.G., ed., Metamorphic and crustal evolution of the western United States: Rubey Volume VII, Prentice Hall, Englewood Cliffs, N.J, p. 649-682.

Missallati, A.A., 1973, Geology and ore deposits of the Mount Hope mining district, Eureka County, Nevada: Palo Alto, Calif., Stanford University Ph.D. thesis, 235 p.

Moores, E.M., Scott, R.B., and Lumsden, W.W., 1968, Tertiary tectonics of the White Pine-Grant Range region, east-central Nevada, and some regional implications: Geological Society of America Bulletin, v. 79, p. 1703-1726.

Morabbi, M., 1980, The geology and ore deposits of Cherry Creek Pluton, White Pine County, Nevada: Boise, Idaho, Idaho State University M.S. thesis, 92 p. 
Mortensen, J.K., Thompson, J.F.H., and Tosdal, R.M., 2000, $\mathrm{U}-\mathrm{Pb}$ age constraints on magmatism and mineralization in the northern Great Basin, in Cluer, J. K., and others, eds., Geology and ore deposits 2000: Geological Society of Nevada, The Great Basin and Beyond Symposium, May 15-18, 2000, Proceedings, p. 419-438.

Morton, J.L., Silberman, M.L., Bonham, H.F., Garside, L.J., and Noble, D.C., 1977, K-Ar ages of volcanic rocks, plutonic rocks, and ore deposits in Nevada and eastern California: Isochron/West, no. 20, p. 19-29.

Mueller, K.J., 1992, Tertiary basin development and exhumation of the northern East Humboldt-Wood Hills metamorphic complex, Elko County, Nevada: Laramie, Wyo., University of Wyoming Ph.D. thesis, $312 \mathrm{p}$.

Muffler, L.J.P., 1964, Geology of the Frenchie Creek quadrangle, north-central Nevada: U.S. Geological Survey Bulletin 1179,99 p.

Myers, G.L., 1994, Geology of the Copper Canyon-Fortitude skarn system, Battle Mountain, Nevada: Pullman, Wash., Washington State University Ph.D. dissertation, 338 p.

Nelson, S.W., 1975, The petrology of a zoned granitic stock, Stillwater Range, Churchill County, Nevada: Reno, Nev., University of Nevada M.S. thesis, 102 p.

Nolan, T.B., Merriam, C.W., and Blake, M.C., Jr., 1974, Geologic map of the Pinto Summit quadrangle, Eureka and White Pine Counties, Nevada: U.S. Geological Survey Miscellaneous Investigations Series Map I-793, scale 1:31,680.

Nosker, S.A., 1981, Stratigraphy and structure of the Sou Hills, Pershing County, Nevada: Reno, Nev., University of Nevada M.S. thesis, $60 \mathrm{p}$.

O’Neill, J.M., 1968, Geology of the southern Pilot Range, Elko County, Nevada, and Box Elder and Tooele Counties, Utah: Albuquerque, N. Mex., University of New Mexico M.S. thesis, $113 \mathrm{p}$.

Phinisey, J.D., 1995, Petrography, alteration, and mineralization of igneous dikes of the Jerritt Canyon district, Elko County, Nevada: Reno, Nev., University of Nevada M.S. thesis, $173 \mathrm{p}$.

Pullman, S.A., 1983, The petrography and petrology of a portion of the northern Cedar Mountains, Mineral County, Nevada: Reno, Nev., University of Nevada M.S. thesis, 130 p.

Pullman, S.A., 1984, K-Ar age of the Cedar Mountain pluton, Mineral County, Nevada: Isochron/West, no. 39, p. 17.

Putney, T.R., 1985, Geology, geochemistry, and alteration of the Seligman and Monte Cristo stocks, White Pine mining district, White Pine County, Nevada: Reno, Nev., University of Nevada M.S. thesis, $152 \mathrm{p}$.
Radtke, A.S., 1985, Geology of the Carlin gold deposit, Nevada: U.S. Geological Survey Professional Paper 1267, $124 \mathrm{p}$.

Rahl, J.M., McGrew, A.J., and Foland, K.A., 2002, Transition from contraction to extension in the northeastern Basin and Range-New evidence from the Copper Mountains, Nevada: Journal of Geology, v. 110, p. 179-194.

Ressel, M.W., Jr., 2005, Igneous geology of the Carlin trend, Nevada-The importance of Eocene magmatism in gold mineralization: Reno, Nev., University of Nevada Ph.D. thesis, $266 \mathrm{p}$.

Ressel, M.W., and Henry, C.D., 2006, Igneous geology of the Carlin trend, Nevada-Development of the Eocene plutonic complex and significance for Carlin-type gold deposits: Economic Geology, v. 101, p. 347-384.

Ressel, M.W., Noble, D.C., Heizler, M.T., Volk, J.A., Lamb, J.B., Park, D.E., Conrad, J.E., and Mortensen, J.K., 2000, Gold-mineralized Eocene dikes at Griffin and Meikle, bearing on the age and origin of deposits of the Carlin Trend, Nevada, in Cluer, J.K., and others, eds., Geology and ore deposits 2000: Geological Society of Nevada, The Great Basin and Beyond Symposium, May 15-18, 2000, Proceedings, p. 79-101.

Roberts, R.J., 1964, Stratigraphy and structure of the Antler Peak quadrangle, Humboldt and Lander Counties, Nevada: U.S. Geological Survey Professional Paper 459-A, 93 p.

Ross, D.C., 1961, Geology and mineral deposits of Mineral County, Nevada: Nevada Bureau of Mines and Geology Bulletin 58, 98 p.

Sayeed, U.A., 1973, Petrology and structure of Kern Mountains plutonic complex, White Pine County, Nevada, and Juab County, Utah: Lincoln, Nebr., University of Nebraska Ph.D. dissertation 134 p.

Schilling, J.H., 1965, Potassium-argon ages of the granitic intrusive rocks: U.S. Atomic Energy Commission Report VUF-1001, p. 159-164.

Seymour, R.S., 1980, Petrology and geochemistry of the Coffeepot stock, N.E. Nevada-A record of crystallization history and hydrothermal fluid migrations: Eugene, Oreg., University of Oregon M.S. thesis, 237 p.

Shaver, S.A., and Jeanne, R.A., 1996, The geology and evolution of the weakly $\mathrm{Au}-(\mathrm{Cu})$-mineralized far eastern side of the Robinson Mining District, Ely, Nevada, in Coyner, A.R., and Fahey, P.L., eds., Geology and ore deposits of the American Cordillera: Geological Society of Nevada, Symposium Proceedings, April 10-13, 1995, p. 1623-1637.

Shawe, D.R., 1961, Rhyolites in the Egan Range south of Ely, Nevada: U.S. Geological Survey Professional Paper 424-B, p. B178-B181. 
Shawe, D.R., 1995, Geologic map of the Round Mountain quadrangle, Nye County, Nevada: U.S. Geological Survey Geologic Quadrangle Map GQ-1756, scale 1:24,000.

Shawe, D.R., 1999, Geologic map of the Manhattan quadrangle, Nye County, Nevada: U.S. Geological Survey Geologic Quadrangle Map GQ-1775, 22 p., scale 1:24,000.

Shawe, D.R., 2003, Geochemistry, geochronology, mineralogy, and geology suggest sources of and controls on mineral systems in the southern Toquima Range, Nye County, Nevada, with geochemistry maps of Gold, silver, mercury, arsenic, antimony, zinc, copper, lead, molybdenum, bismuth, iron, titanium, vanadium, cobalt, beryllium, boron, fluorine, and sulfur by D.R. Shawe and J.D. Hoffman and with a section on Lead associations, mineralogy and paragenesis, and isotopes by D.R. Shawe, B.R. Doe, E.E. Foord, H.J. Stein, and R.A. Ayuso: U.S. Geological Survey Miscellaneous Field Studies Map MF-2327-C, 68 p.

Shawe, D.R., and Lepry, L.B., Jr., 1985, Analytical data for rock samples from the Round Mountain and Manhattan quadrangles, Nye County, Nevada: U.S. Geological Survey Open-File Report 85-0538, 38 p.

Shawe, D.R., Marvin, R.F., Andriessen, P.A.M., Mehnert, H.H., and Merritt, V.M., 1986, Ages of igneous and hydrothermal events in the Round Mountain and Manhattan gold districts, Nye County, Nevada: Economic Geology, v. 81, p. 388-407.

Shawe, F.R., Reeves, R.G., and Kral, V.E., 1962, Iron ore deposits of Nevada - part C; Iron ore deposits of northern Nevada: Nevada Bureau of Mines and Geology, Bulletin 53 , p. $79-128$.

Silberling, N.J., and John, D.A., 1989, Geologic map of preTertiary rocks of the Paradise Range and southern Lodi Hills, west-central Nevada: U.S. Geological Survey Miscellaneous Field Studies Map MF-2062, scale 1:24,000.

Silberman, M.L., Berger, B.R., and Koski, R.A., 1974, K-Ar age relations of granodiorite emplacement and tungsten and gold mineralization near the Getchell mine, Humboldt County, Nevada: Economic Geology, v. 69, p. 646-656.

Silberman, M.L., and McKee, E.H., 1971, K-Ar ages of granitic plutons in north-central Nevada: Isochron/West, no. 1, p. 15-22.

Slack, J.F., 1974, Jurassic suprastructure in the Delano Mountains, northeastern Elko County, Nevada: Geological Society of America Bulletin, v. 85, p. 269-272.

Sloan, J., Henry, C.D., Hopkins, M., Ludington, S., Zartman, R.E., Bush, C.A., and Abston, C., 2003, National geochronological database: U.S. Geological Survey Open-File Report 03-236, 6 tables.
Smith, J.F., Jr., and Ketner, K.B., 1976, Stratigraphy of postPaleozoic rocks and summary of resources in the Carlin-Pinon Range area, Nevada: U.S. Geological Survey Professional Paper 867-B, 48 p.

Smith, J.G., McKee, E.H., Tatlock, D.B., and Marvin, R.F., 1971, Mesozoic granitic rocks in northwestern Nevada-A link between the Sierra Nevada and Idaho batholiths: Geological Society of America Bulletin, v. 82, p. 2935-2944.

Smith, M.R., 1981, Geology and mineralization of the southeastern Gillis Range, Mineral County, Nevada: Reno, Nev., University of Nevada M.S. thesis, 103 p.

Speed, R.C., and Armstrong, R.L., 1971, Potassium-argon ages of some minerals from igneous rocks of western Nevada: Isochron/West, no. 1, p. 1-8.

Speed, R.C., and McKee, E.H., 1976, Age and origin of the Darrough Felsite, southern Toiyabe Range, Nevada: U.S. Geological Survey Journal of Research, v. 4, p. 75-81.

Spencer, A.C., 1917, The geology and ore deposits of Ely, Nevada: U.S. Geological Survey Professional Paper 96, 189 p.

Stablein, N.K., 1969, Petrogenesis of microcline megacrysts in the New York Canyon pluton, Stillwater Range, Nevada: Evanston, Ill., Northwestern University M.S. thesis, 81 p.

Starkey, K.J., 1987, Geology, petrography, chemistry and petrogenesis of the Nannies Peak intrusive complex, Elko County, Nevada: Laramie, Wyo., University of Wyoming M.S. thesis, scale 1:24,000.

Stewart, J.H., and Carlson, J.E., 1978, Geologic map of Nevada: U.S. Geological Survey, scale 1:500,000.

Stewart, J.H., and McKee, E.H., 1977, Geology and mineral deposits of Lander County, Nevada: Nevada Bureau of Mines and Geology Bulletin 88, 106 p.

Streckeisen, A.L., 1973, Plutonic rocks, classification and nomenclature recommended by the IUGS subcommission on the systematics of igneous rocks: Geotimes, v. 18, no. 10, p. 26-30.

Strike, A.T., 2000, Deep crustal flow, Tertiary magmatism and mylonitization in middle crustal rocks, Liberty Pass-Wines Peak area, northern Ruby Mountains, Elko County Nevada: Laramie, Wyo., University of Wyoming M.S. thesis, 105 p.

Taylor, J.K., 1982, Geology of the Nevada Scheelite mine, Mineral County, Nevada: Reno, Nev., University of Nevada M.S. thesis, $94 \mathrm{p}$. 
Theodore, T.G., 2000, Geology of pluton-related gold mineralization at Battle Mountain, Nevada, with a section on Potassium-argon chronology of Cretaceous and Cenozoic igneous activity, hydrothermal alteration, and mineralization by E.H. McKee, and a section on Lone Tree gold deposit by E.I.

Bloomstein, B.L. Braginton, R.W. Owen, R.L. Parrat, K.C. Raabe, and W.F. Thompson, and a section on Geology of the Marigold Mine area by D.H. McGibbon and A.B. Wallace, and a section on Geology, mineralization, and exploration history of the Trenton Canyon project by R.P. Felder: Tucson, Ariz., University of Arizona and U.S. Geological Survey Center for Mineral Resources, Monograph 2, 271 p.

Theodore, T.G., Blake, D.W., Loucks, T.A., and Johnson, C.A., 1992, Geology of the Buckingham stockwork molybdenum deposit and surrounding area, Lander County, Nevada: U.S. Geological Survey Professional Paper 798-D, p. D1-D307.

Theodore, T.G., Silberman, M.L., and Blake, D.W., 1973, Geochemistry and K-Ar ages of plutonic rocks in the Battle Mountain mining district, Lander County, Nevada: U.S. Geological Survey Professional Paper 798-A, 24 p.

Thole, R.H., and Prihar, D.W., 1998, Geologic map of the Eugene Mountains, northwestern Nevada: Nevada Bureau of Mines and Geology Map 115, scale, 1:24,000, 12 p.

Thurber, J.E., 1982, Petrology and Cu-Mo mineralization of the Kennedy stock, East Range, Pershing County, Nevada: Fort Collins, Colo., Colorado State University M.S. thesis, $101 \mathrm{p}$.

Tingley, J.V., 1975, K-Ar dates on granodiorites and related scheelite-bearing quartz veins at Tungsten, Pershing County, Nevada: Isochron/West, no. 12, p. 3-4.

Vikre, P.G., 1985, Precious metal vein systems in the National district, Humboldt County, Nevada: Economic Geology, v. 80 , p. $360-393$.
Wells, J.D., Elliott, J.E., and Obradovich, J.D., 1971, Age of the igneous rocks associated with ore deposits, CortezBuckhorn area, Nevada: U.S. Geological Survey Professional Paper 750-C, p. C127-C135.

Westra, G., and Riedell, K.B., 1996, Geology of the Mt. Hope stockwork molybdenum deposit, Eureka County, Nevada, in Coyner, A.R., and Fahey, P.L., eds., Geology and ore deposits of the American Cordillera: Geological Society of Nevada Symposium Proceedings, April 10-13, 1995, p. 1639-1666.

Whitebread, D.H., 1994, Geologic map of the Dun Glen quadrangle, Pershing County, Nevada: U.S. Geological Survey Miscellaneous Investigations Series Map I-2409, scale $1: 48,000$.

Willden, R., 1964, Geology and mineral deposits of Humboldt County, Nevada: Nevada Bureau of Mines and Geology Bulletin 59, $154 \mathrm{p}$.

Willden, R., and Speed, R.C., 1974, Geology and mineral deposits of Churchill County, Nevada: Nevada Bureau of Mines and Geology Bulletin 83, 95 p.

Wooden, J.L., Kistler, R.W., and Tosdal, R.M., 1999, Strontium, lead, and oxygen isotopic data for granitoid and volcanic rocks from the northern Great Basin and Sierra Nevada, California, Nevada and Utah: U.S. Geological Survey Open-File Report 99-569, 20 p.

Wrucke, C.T., and Armbrustmacher, T.J., 1973, Geochemical analyses of bedrock samples collected in the Gold Acres and Tenabo areas, northern Shoshone Range, Nevada: National Technical Information Service PB220645, 136 p.

Wrucke, C.T., and Silberman, M.L., 1975, Cauldron subsidence of Oligocene age at Mount Lewis, northern Shoshone Range, Nevada: U.S. Geological Survey Professional Paper 876,20 p. 


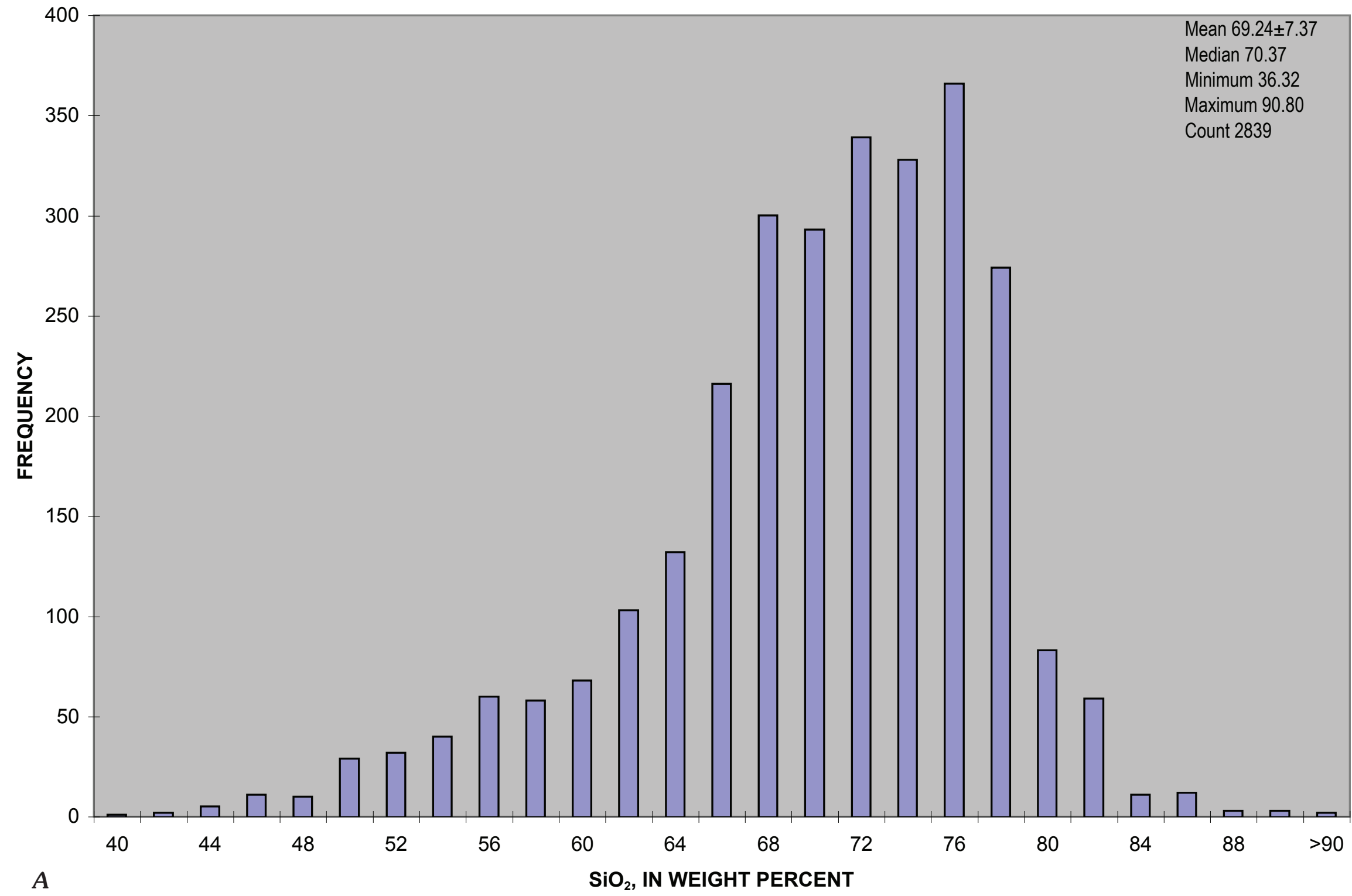

Figure 2 (above and following pages). Frequency distribution histograms showing compositions of north-central and northeast Nevada intrusive rock samples. Height of each histogram bar indicates number of samples whose abundances of indicated component are as much as numeric label beneath bar but greater than value associated with next lower abundance bar (for instance, if two adjacent bars are labeled 90 and 100 and if associated data are reported as whole numbers, the height bar labeled 100 depicts the number of samples with abundances of 91 to 100). Also presented are basic descriptive statistics, including mean and standard deviation, median, minimum, maximum, and

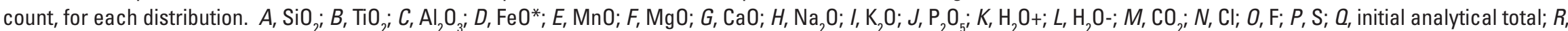
total volatile content; $S$, Ba; T, La; U, Ce; V, Rb; W, Sr; $X, Y ; Y, Z r ; Z, N b ; A A, T h ; B B, \mathrm{Ga} ; C C, \mathrm{Co} ; D D, \mathrm{Cr} ; E E, \mathrm{Ni} ; F F, \mathrm{Sc} ; G G, \mathrm{~V} ; H H, \mathrm{Ag} ; I I, \mathrm{Cu} ; J J, \mathrm{Mo} ; K K, \mathrm{~Pb} ; L L, Z \mathrm{Zn} ; M M, \mathrm{Au}$. 


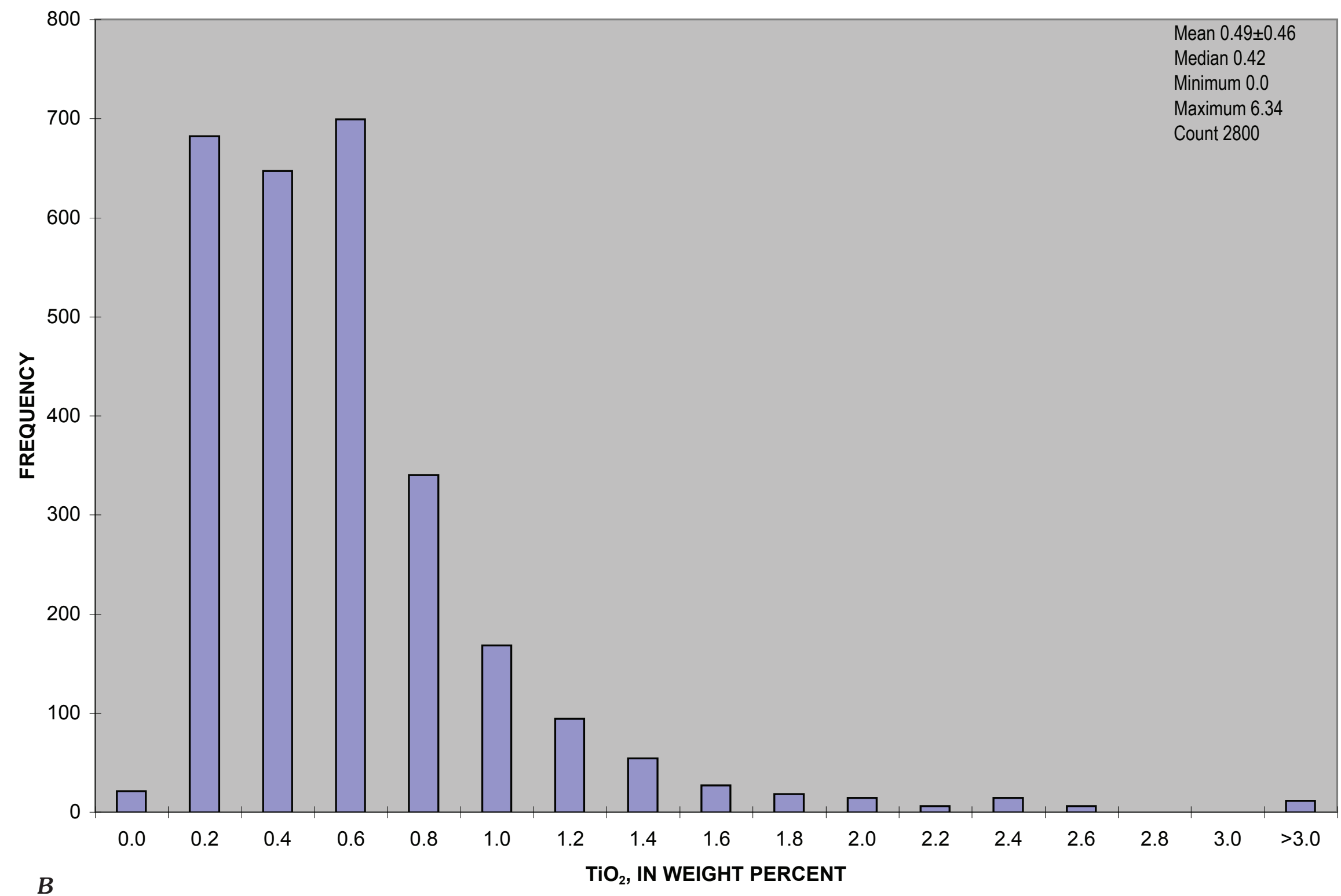

Figure 2. Frequency distribution histograms showing compositions of north-central and northeast Nevada intrusive rock samples-Continued. 


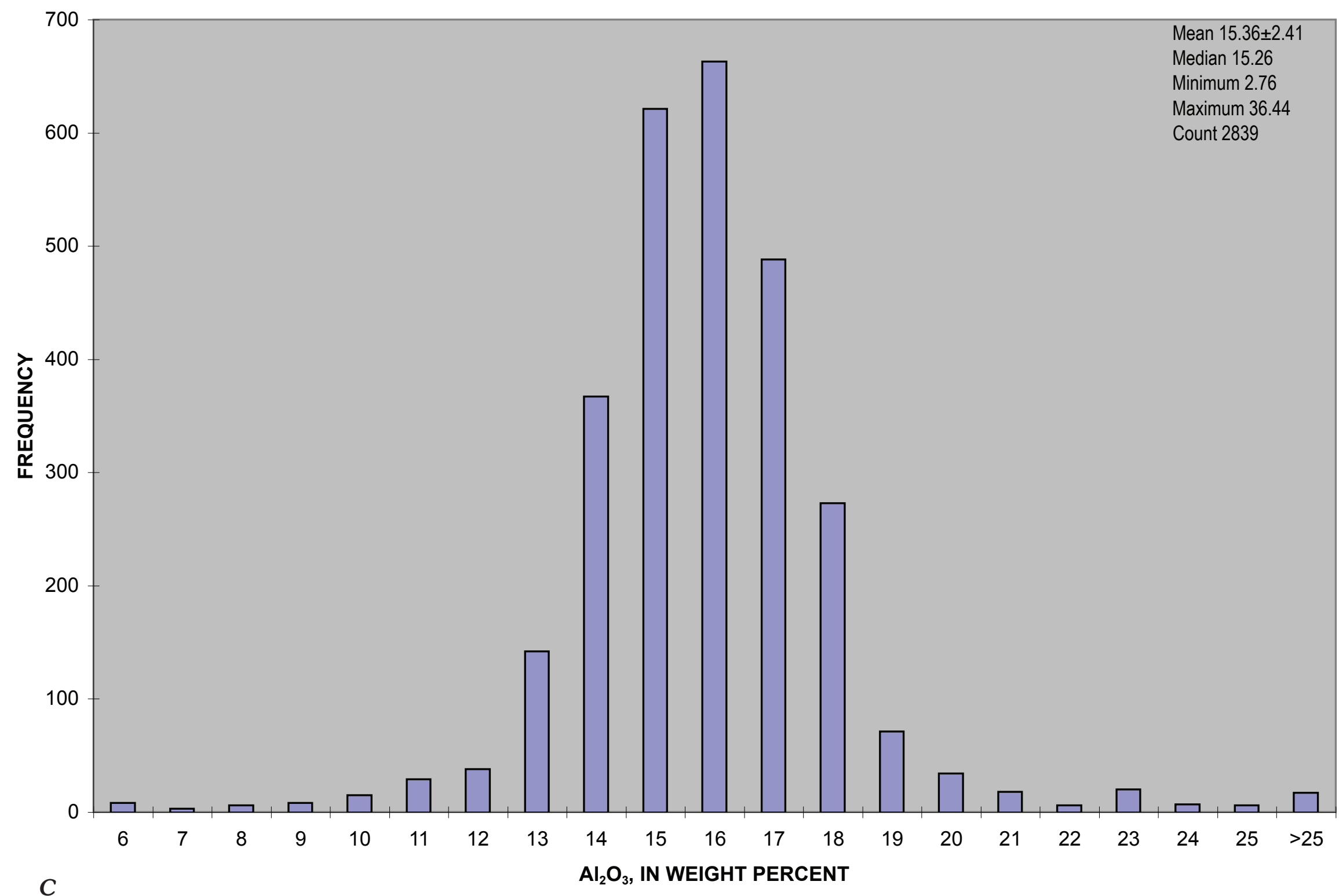

Figure 2. Frequency distribution histograms showing compositions of north-central and northeast Nevada intrusive rock samples-Continued. 


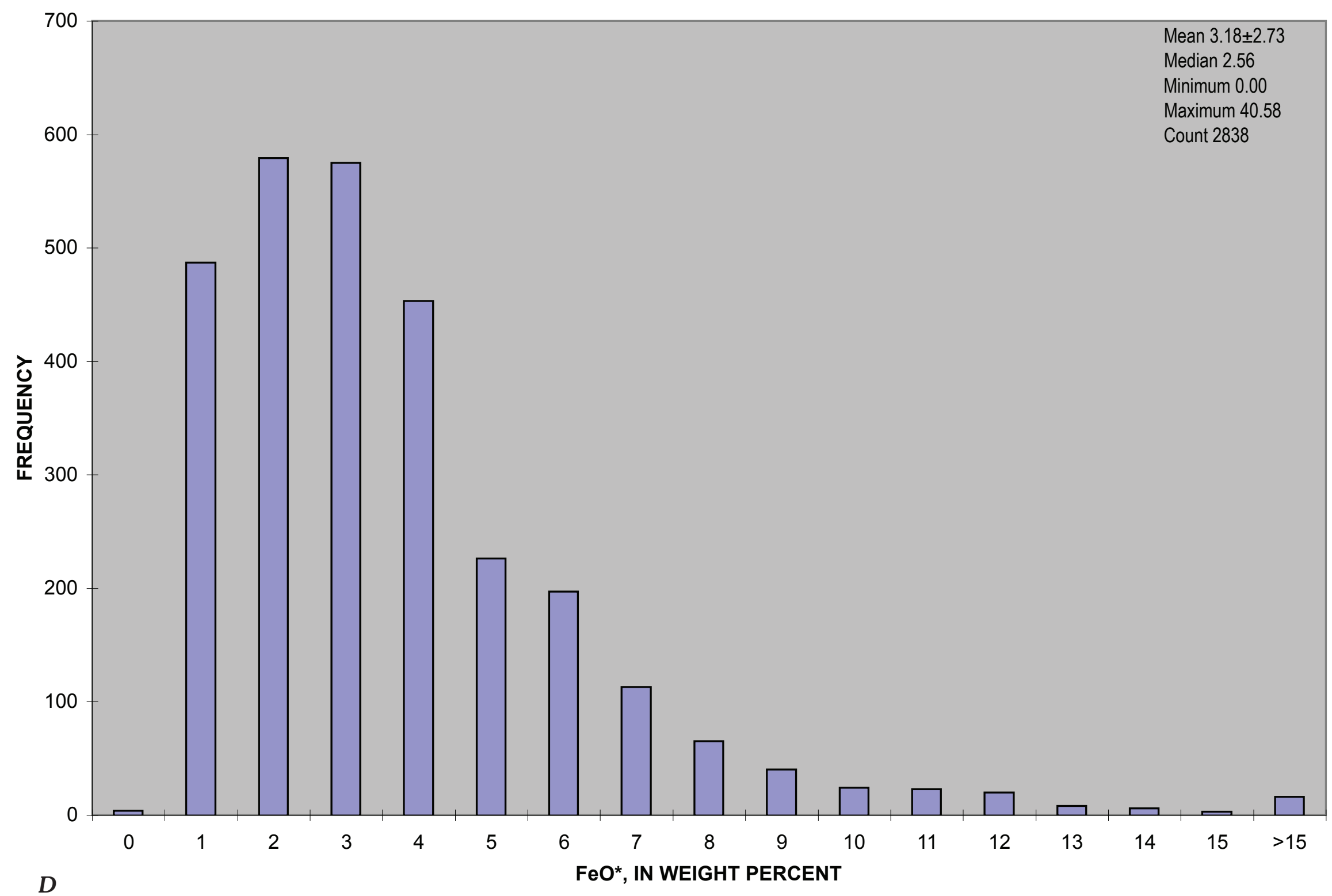

Figure 2. Frequency distribution histograms showing compositions of north-central and northeast Nevada intrusive rock samples—Continued. 


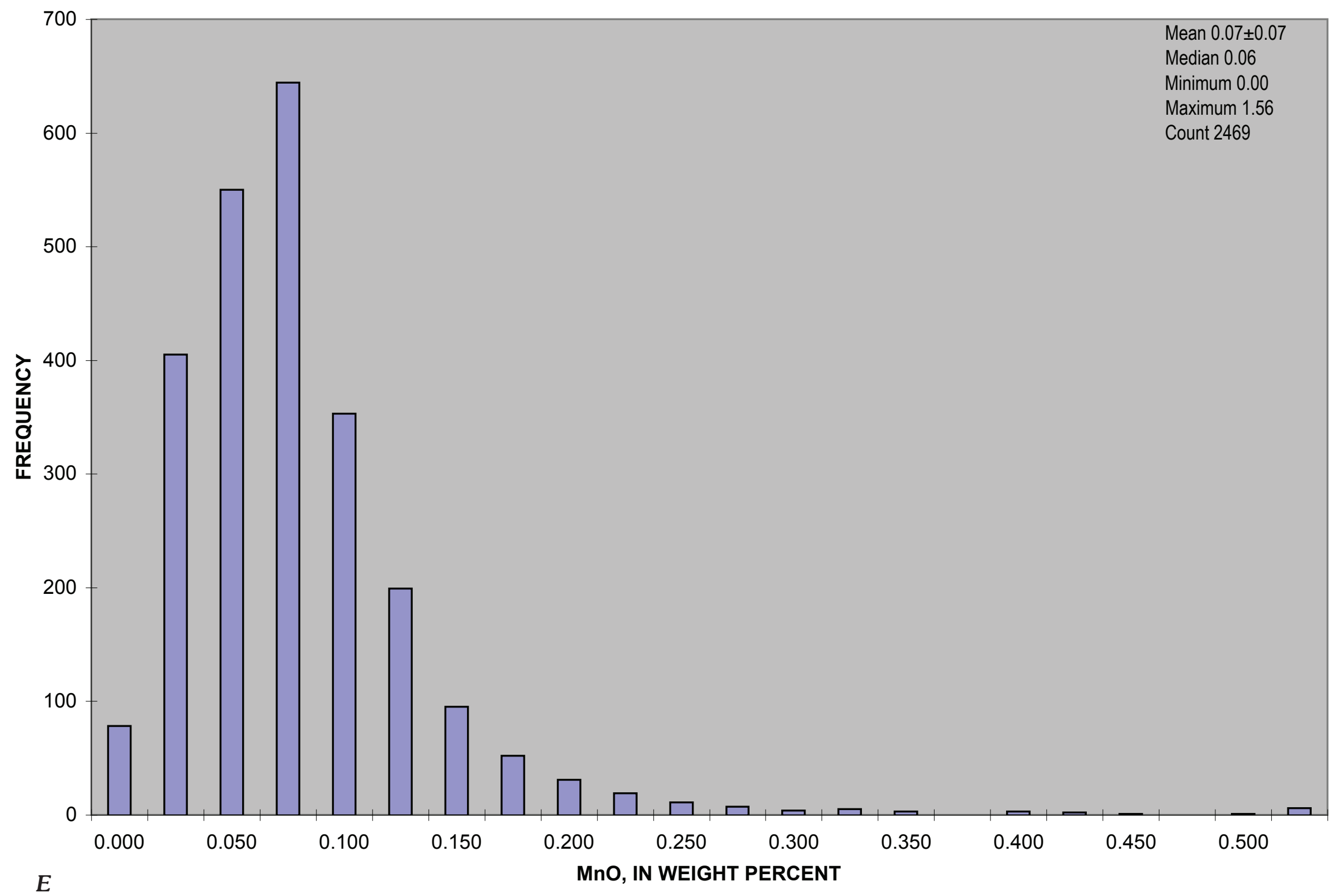

Figure 2. Frequency distribution histograms showing compositions of north-central and northeast Nevada intrusive rock samples—Continued. 


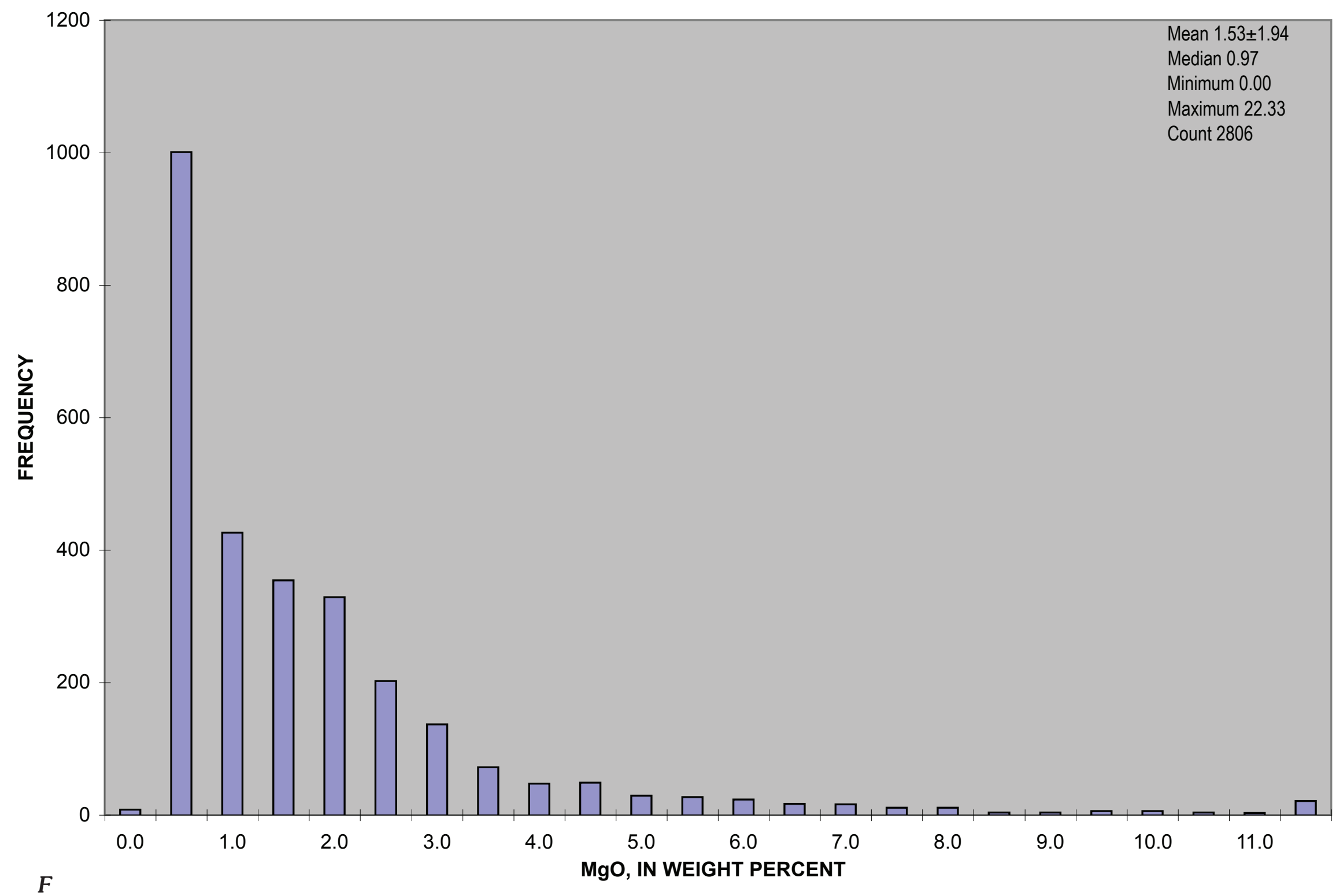

Figure 2. Frequency distribution histograms showing compositions of north-central and northeast Nevada intrusive rock samples—Continued. 


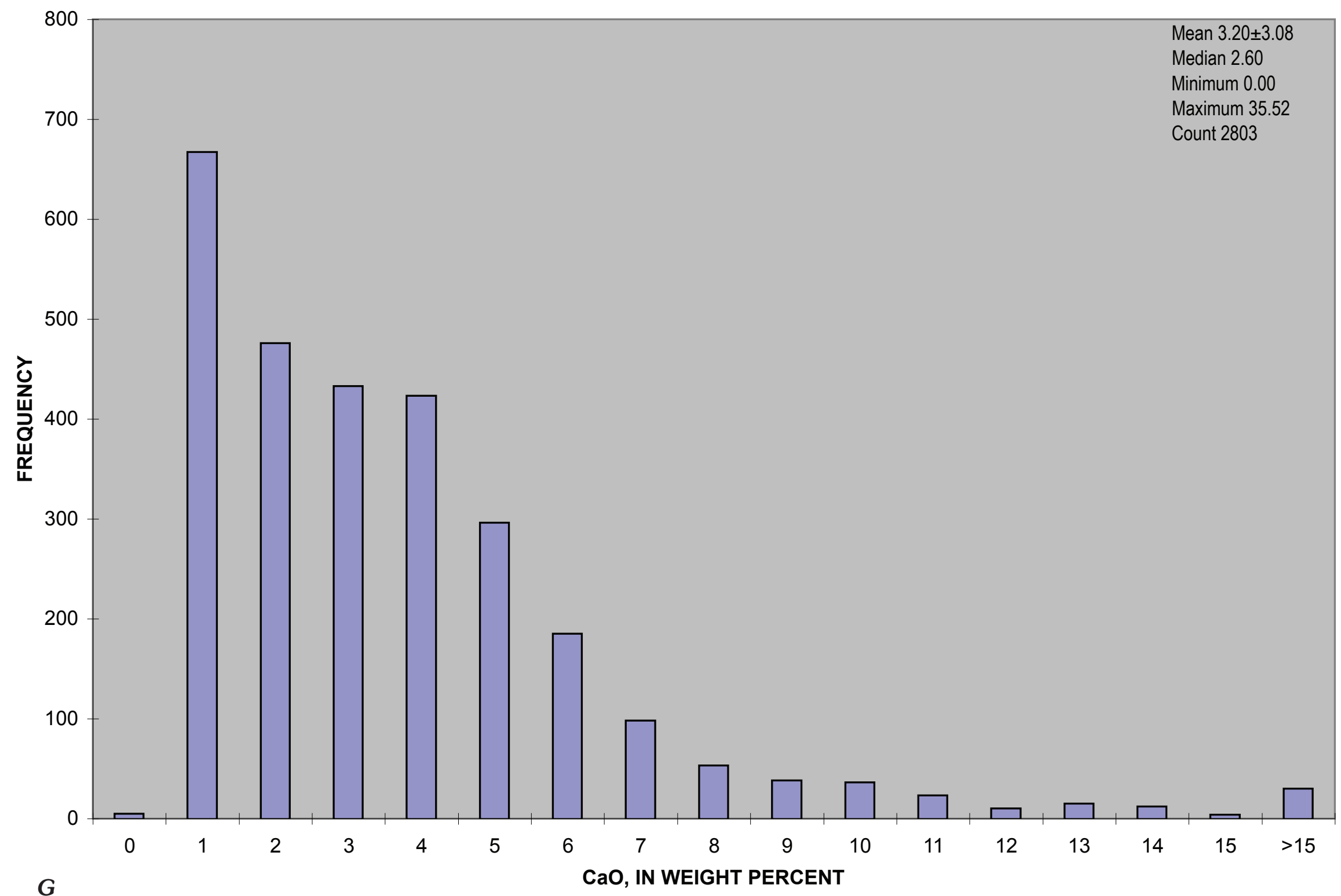

Figure 2. Frequency distribution histograms showing compositions of north-central and northeast Nevada intrusive rock samples—Continued. 


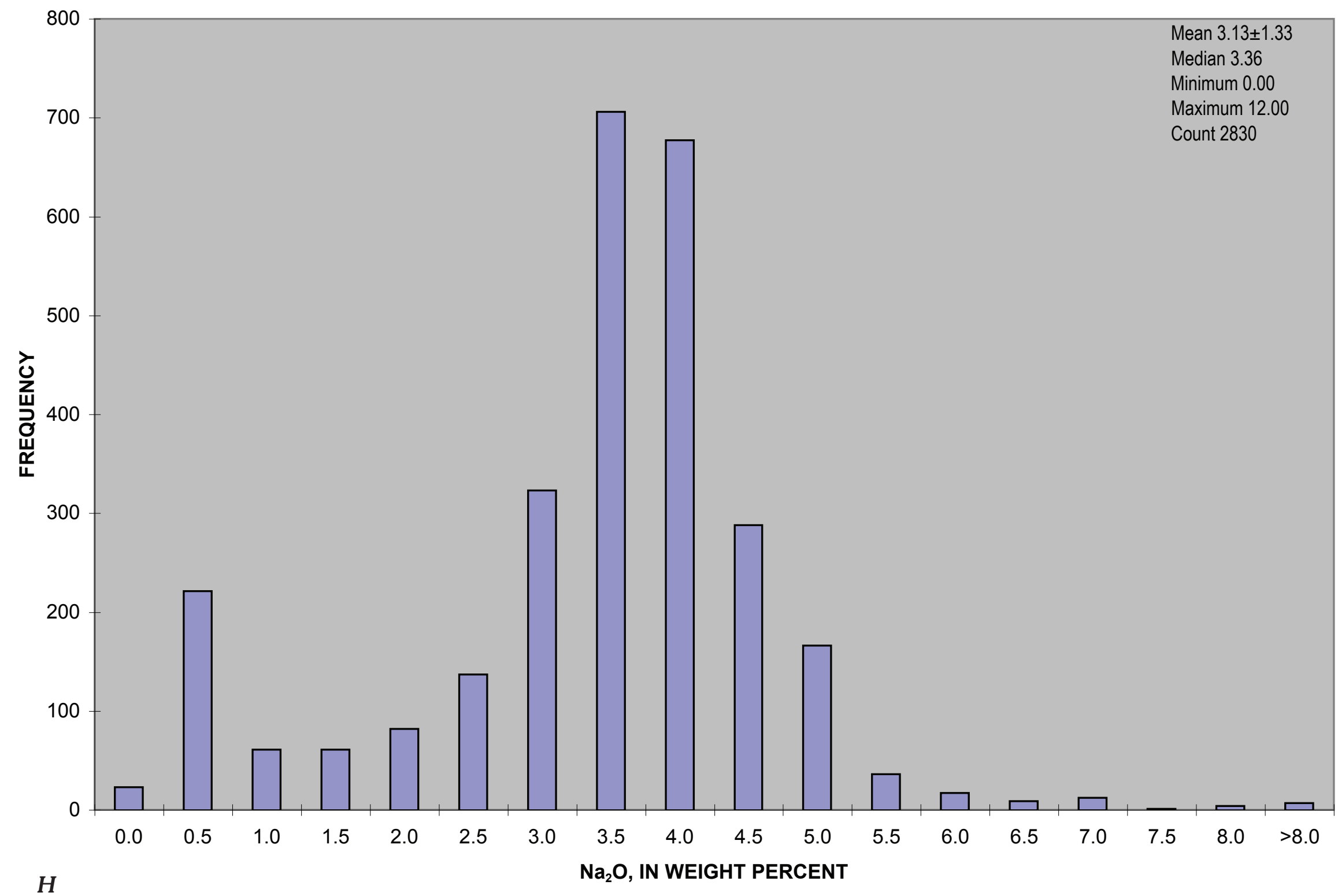

Figure 2. Frequency distribution histograms showing compositions of north-central and northeast Nevada intrusive rock samples—Continued. 


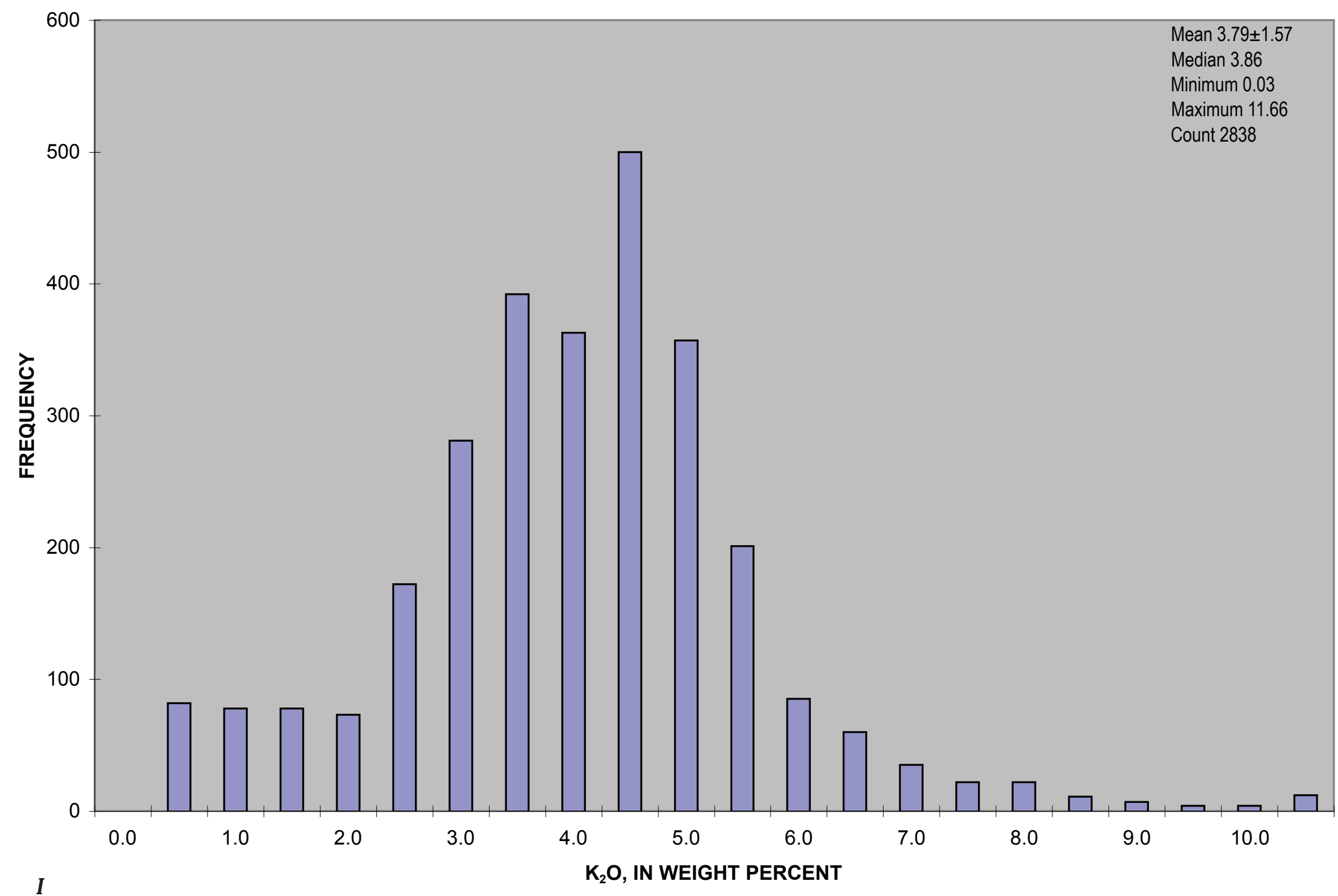

Figure 2. Frequency distribution histograms showing compositions of north-central and northeast Nevada intrusive rock samples-Continued. 


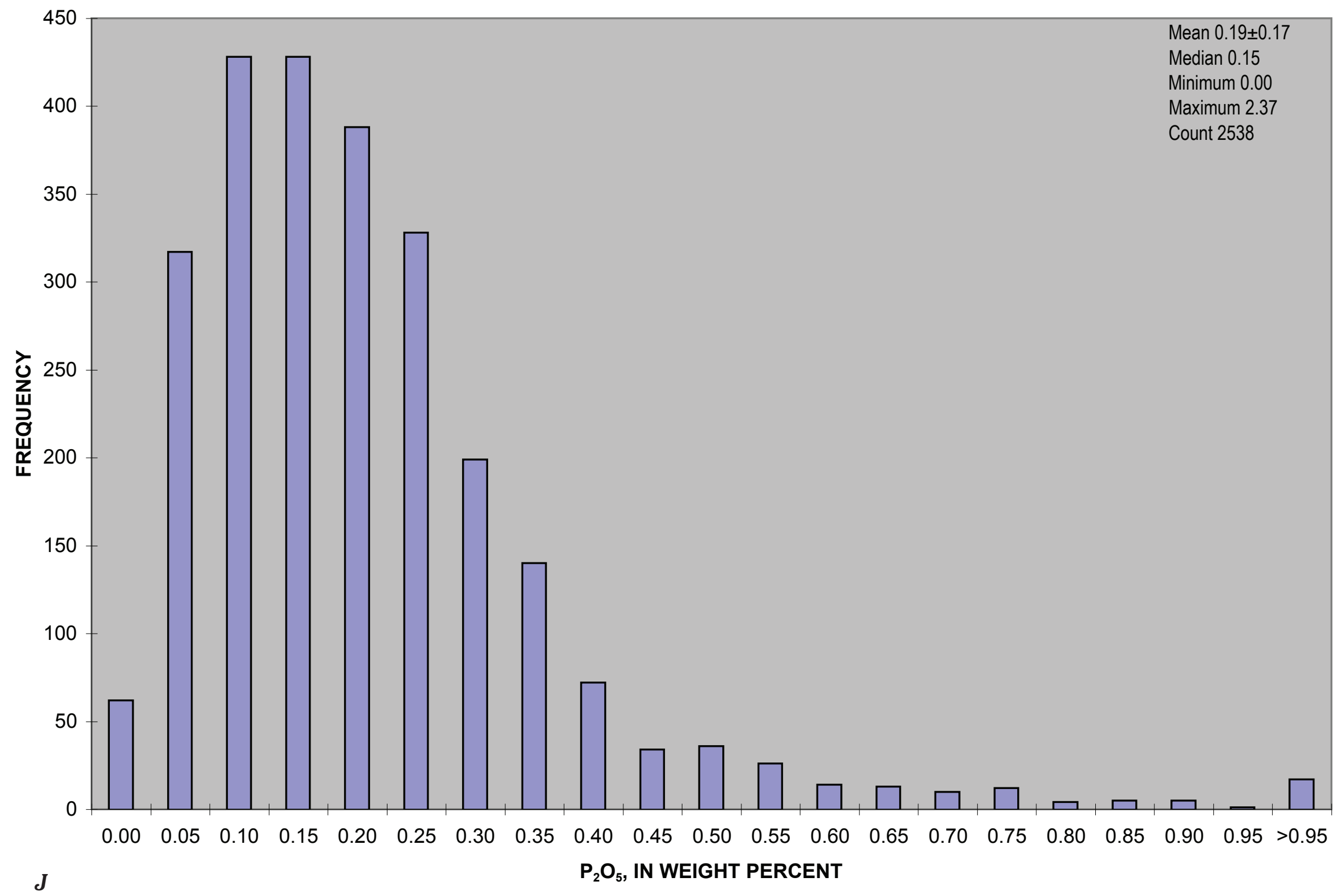

Figure 2. Frequency distribution histograms showing compositions of north-central and northeast Nevada intrusive rock samples-Continued. 


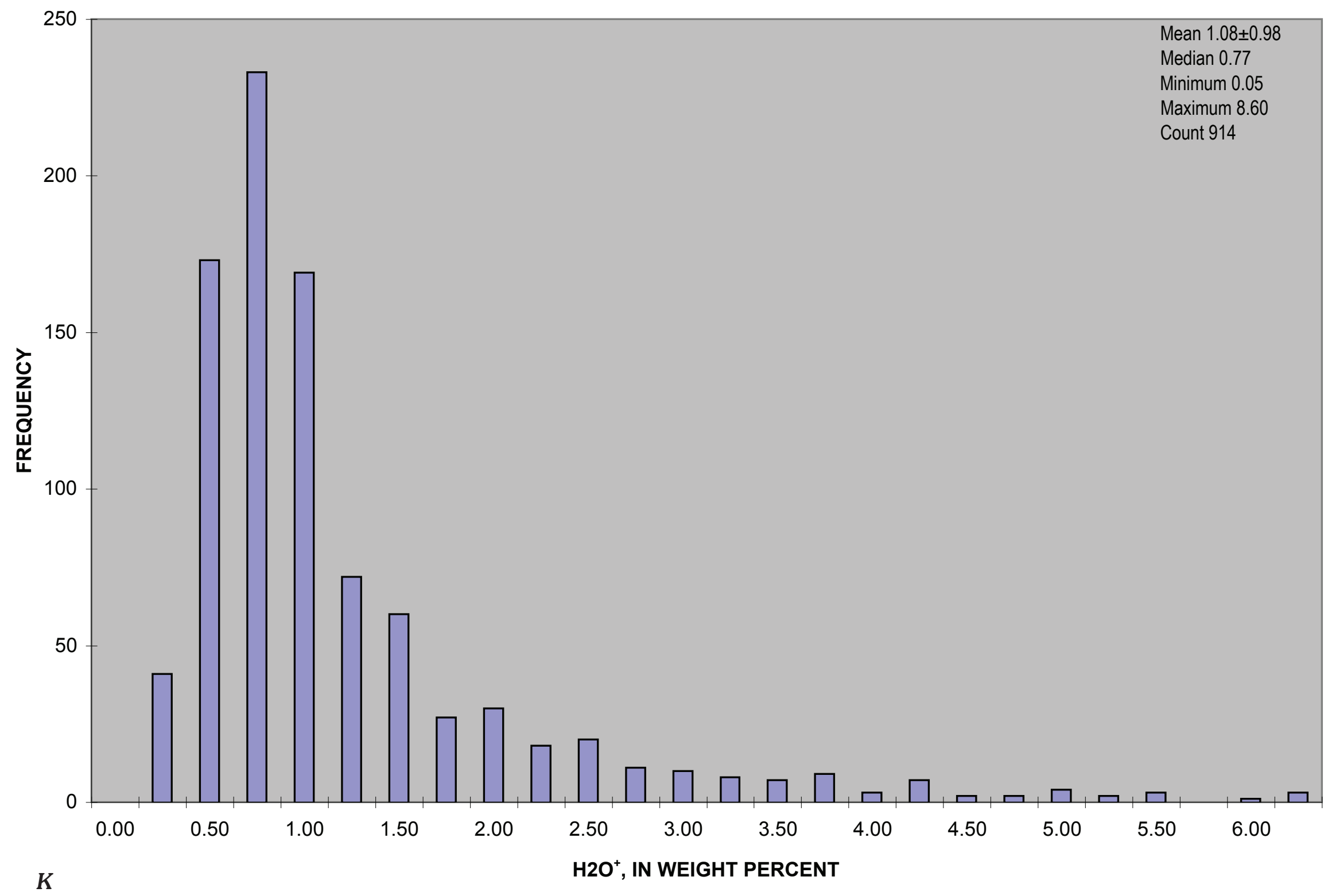

Figure 2. Frequency distribution histograms showing compositions of north-central and northeast Nevada intrusive rock samples—Continued. 


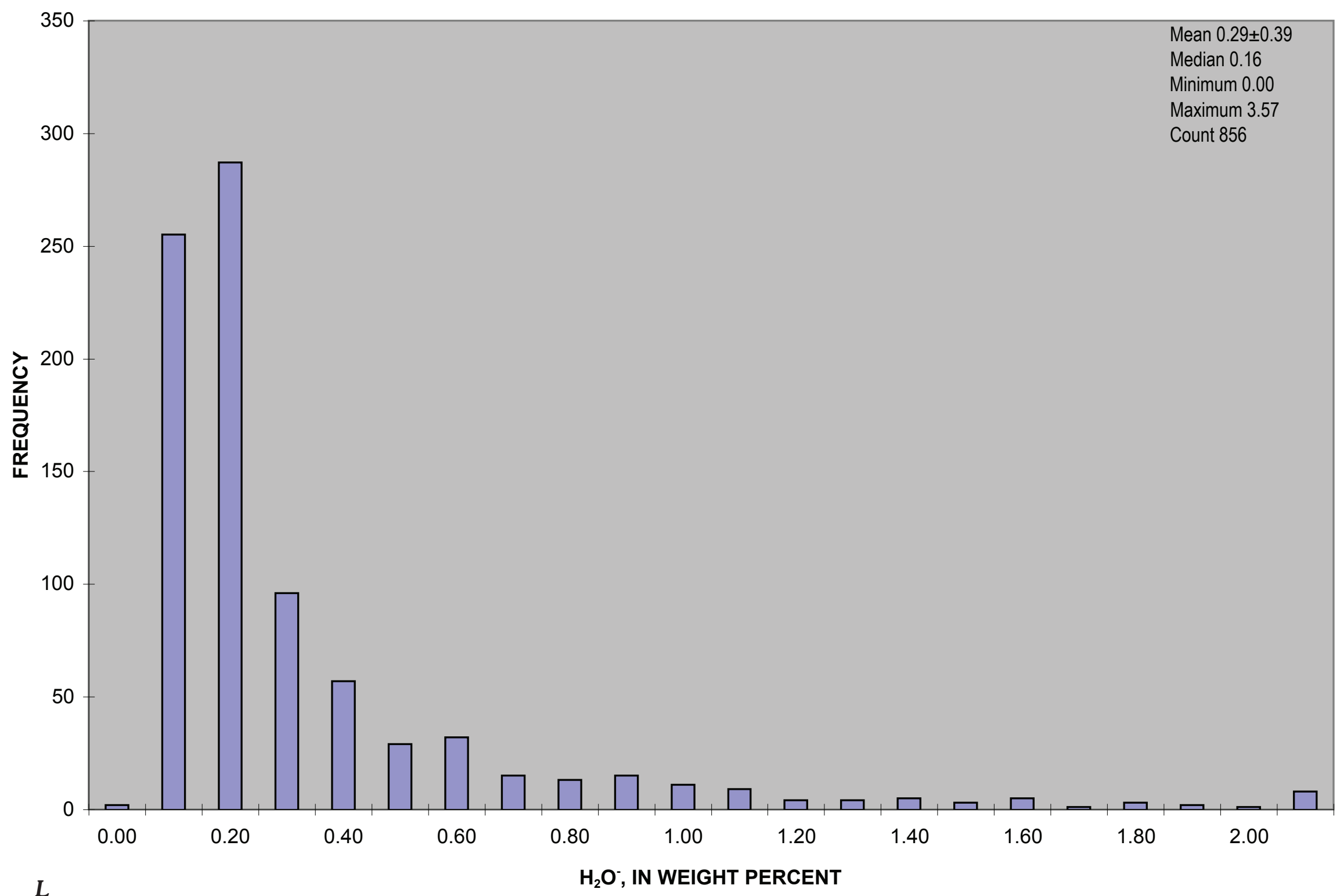

Figure 2. Frequency distribution histograms showing compositions of north-central and northeast Nevada intrusive rock samples-Continued. 


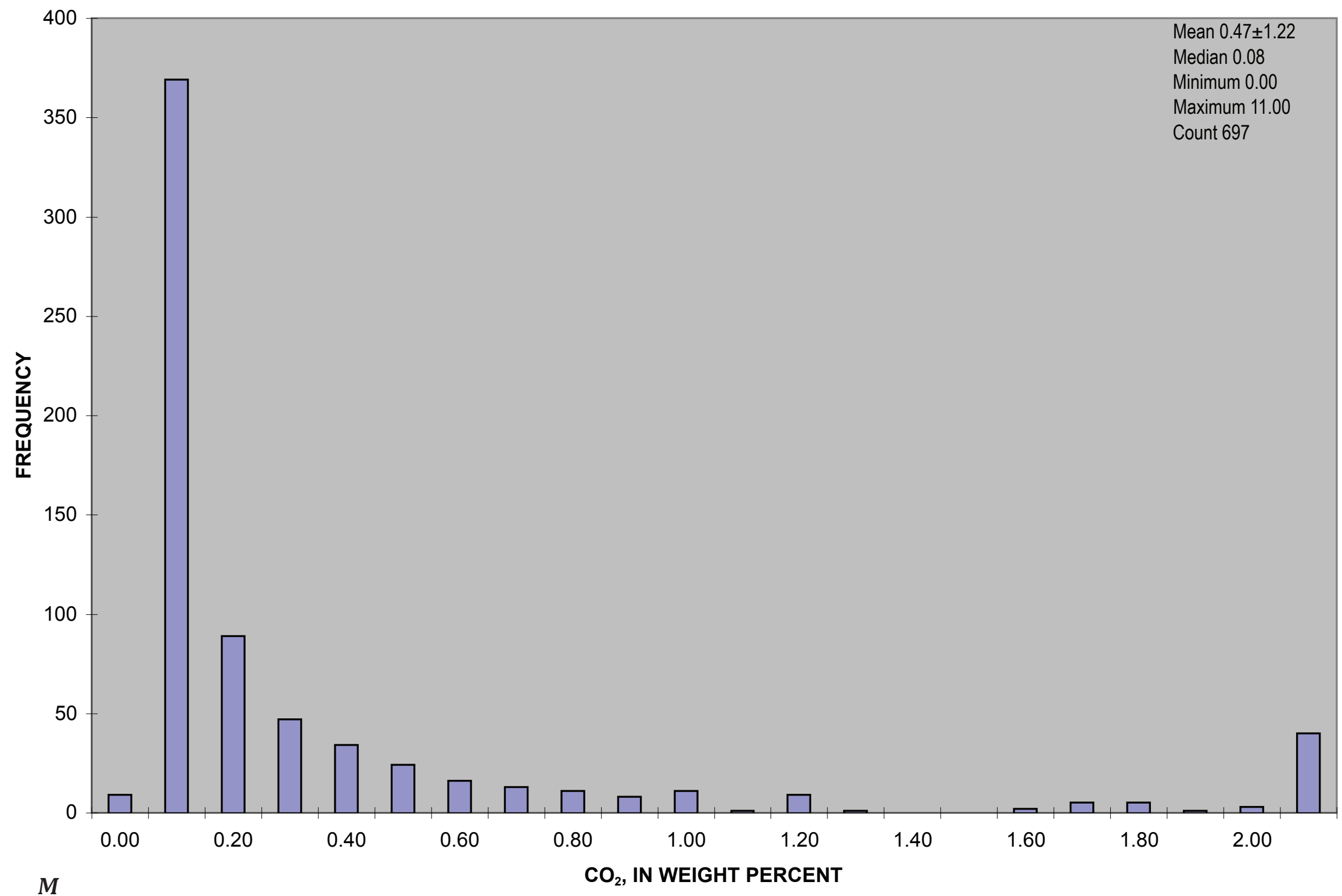

Figure 2. Frequency distribution histograms showing compositions of north-central and northeast Nevada intrusive rock samples—Continued. 


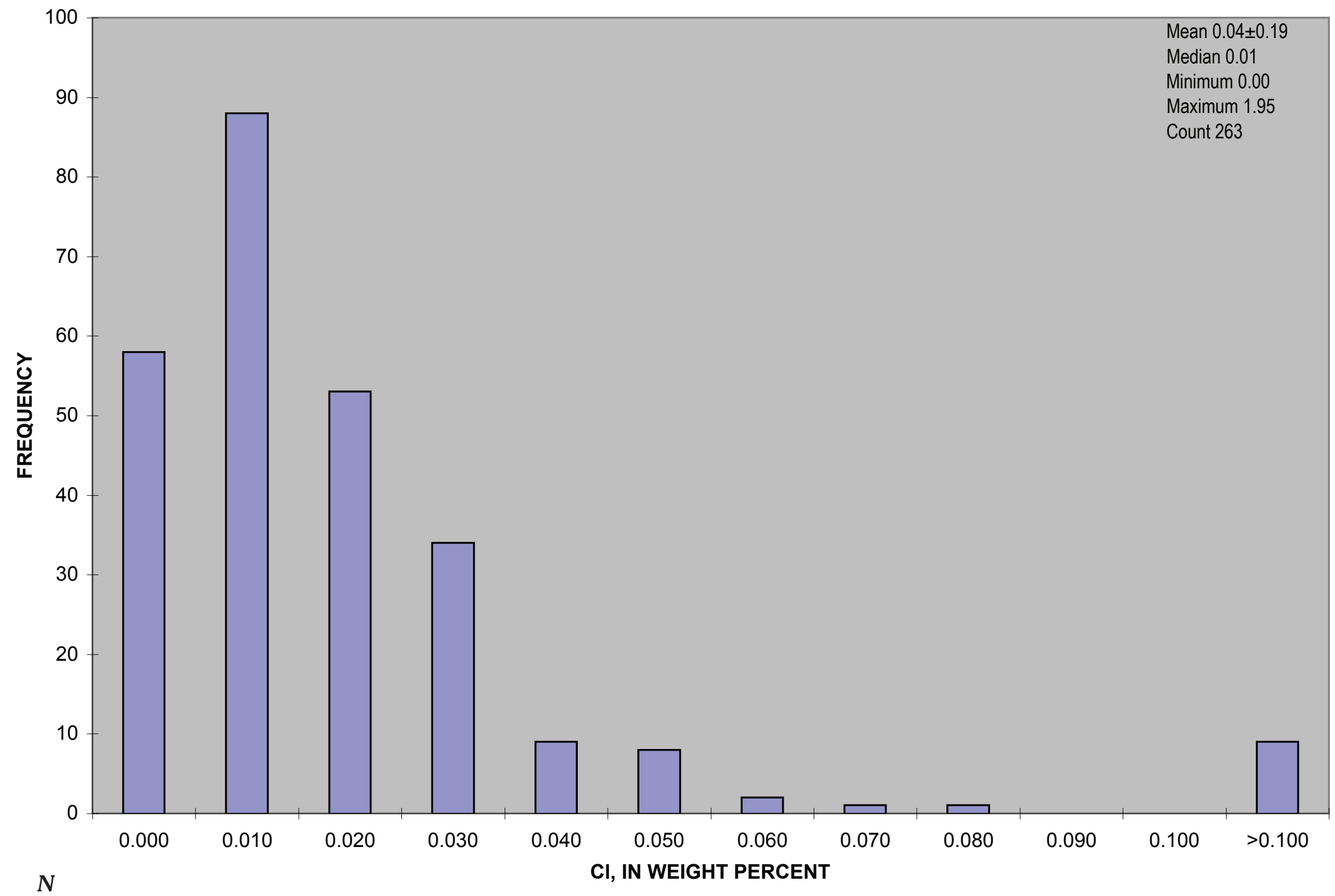

Figure 2. Frequency distribution histograms showing compositions of north-central and northeast Nevada intrusive rock samples-Continued. 


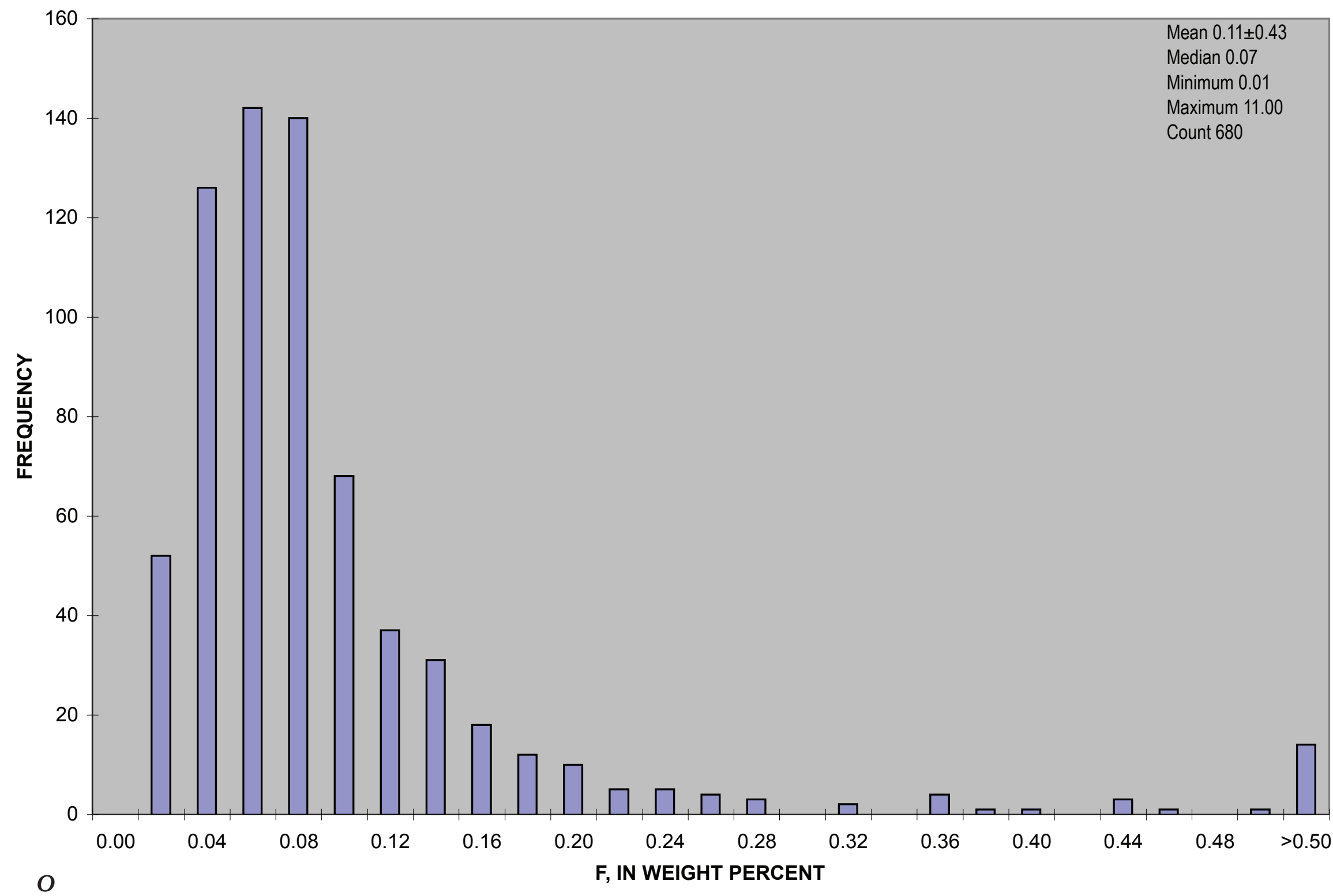

Figure 2. Frequency distribution histograms showing compositions of north-central and northeast Nevada intrusive rock samples-Continued. 


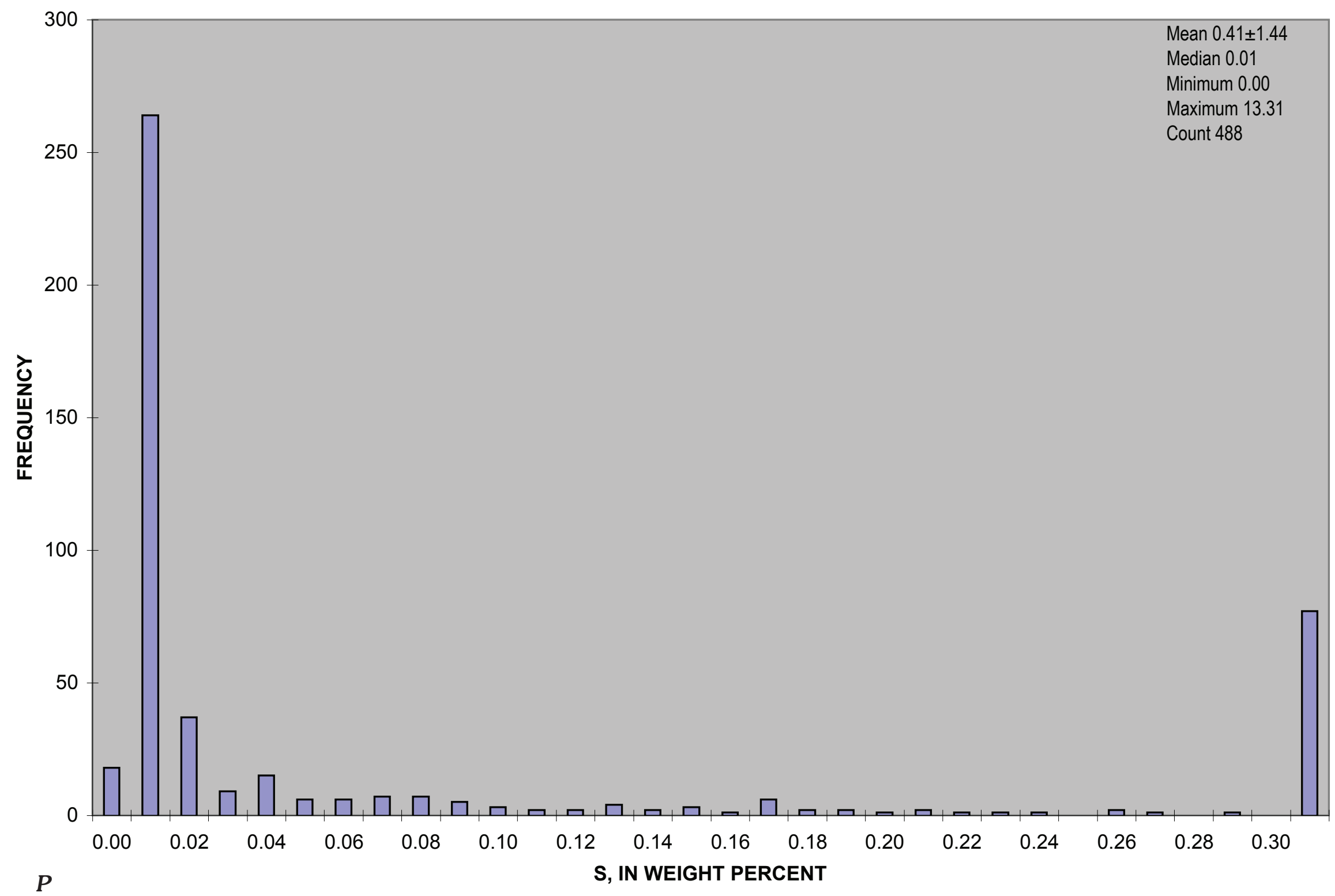

Figure 2. Frequency distribution histograms showing compositions of north-central and northeast Nevada intrusive rock samples-Continued. 


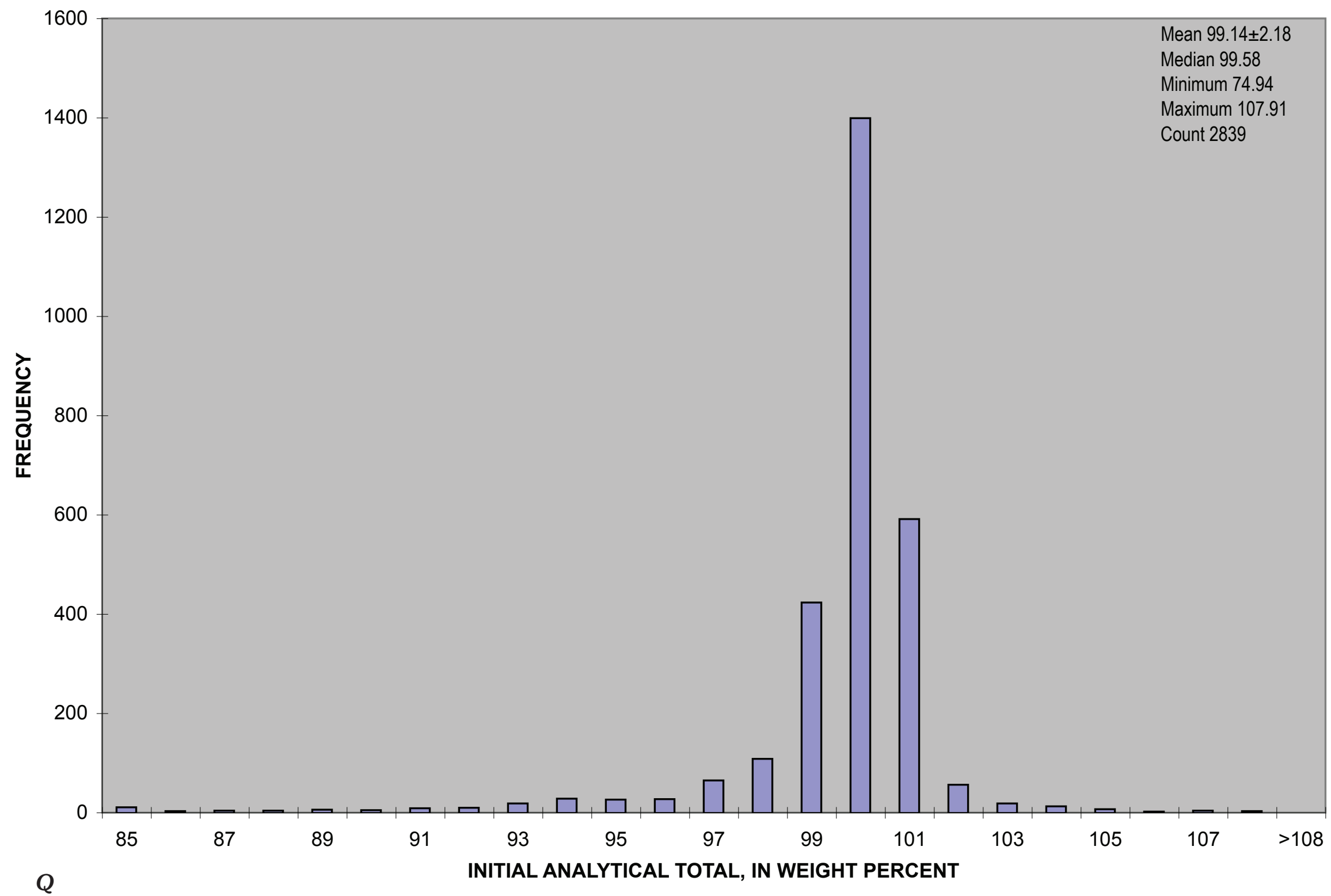

Figure 2. Frequency distribution histograms showing compositions of north-central and northeast Nevada intrusive rock samples—Continued. 


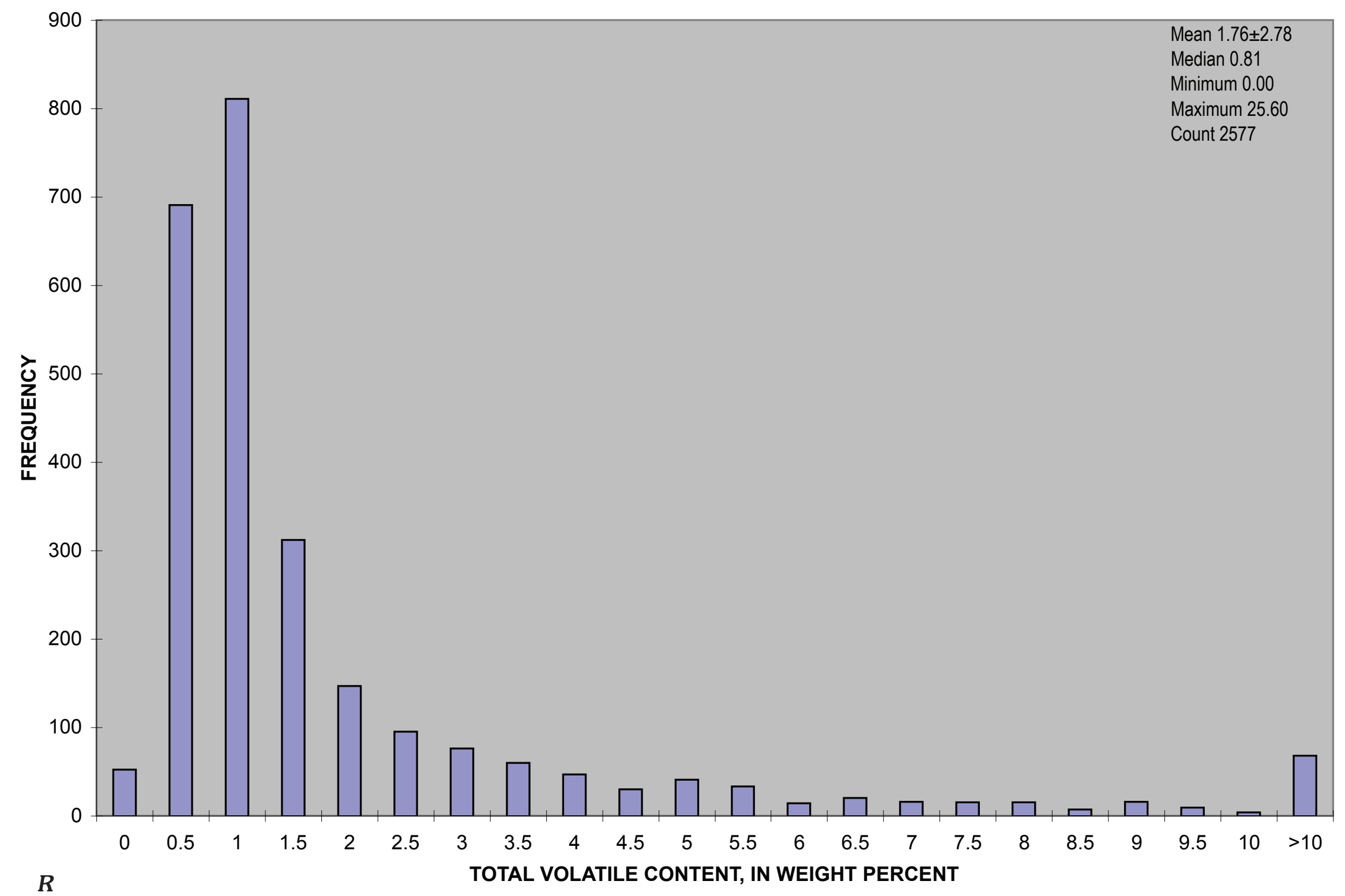

Figure 2. Frequency distribution histograms showing compositions of north-central and northeast Nevada intrusive rock samples—Continued. 


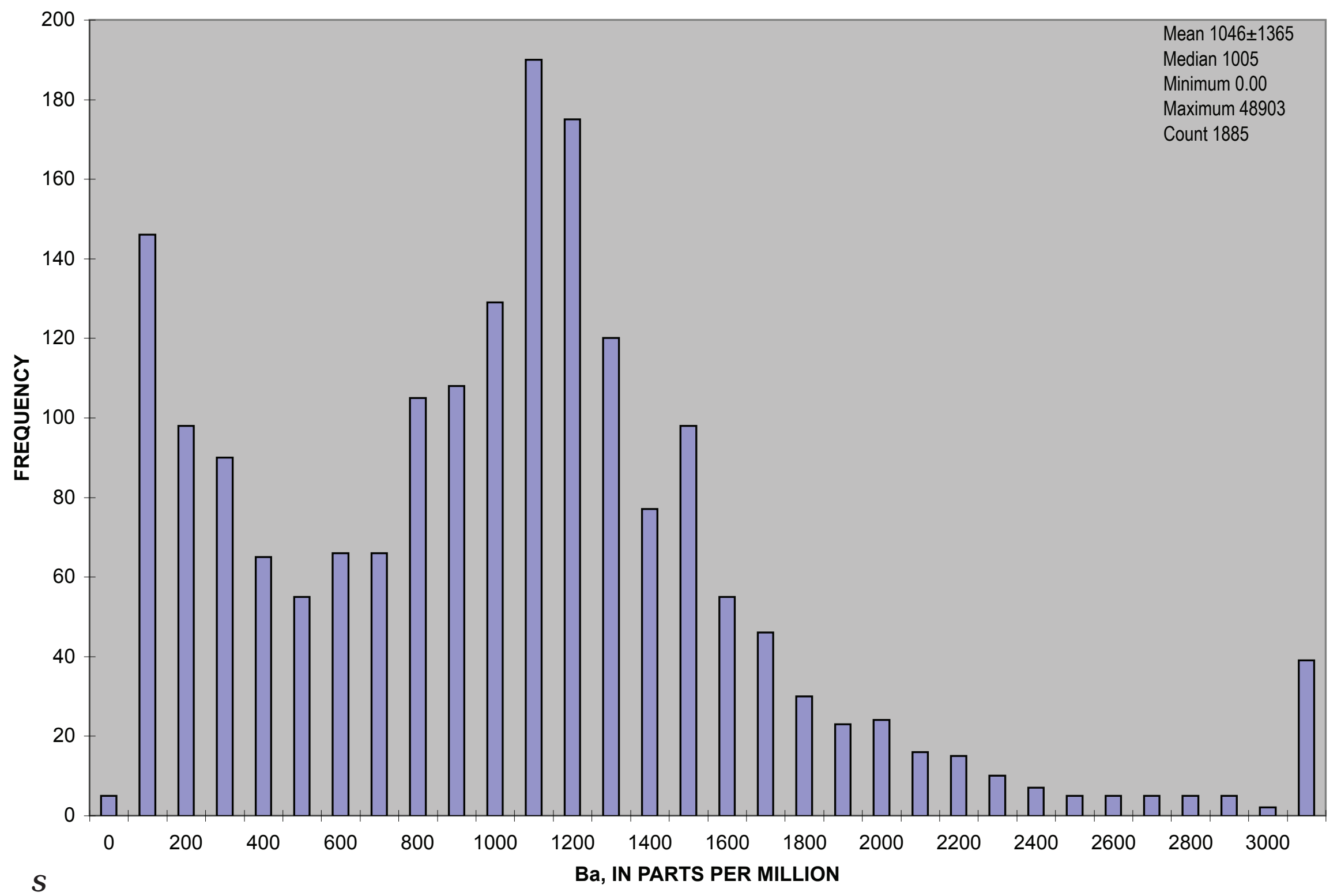

Figure 2. Frequency distribution histograms showing compositions of north-central and northeast Nevada intrusive rock samples—Continued. 


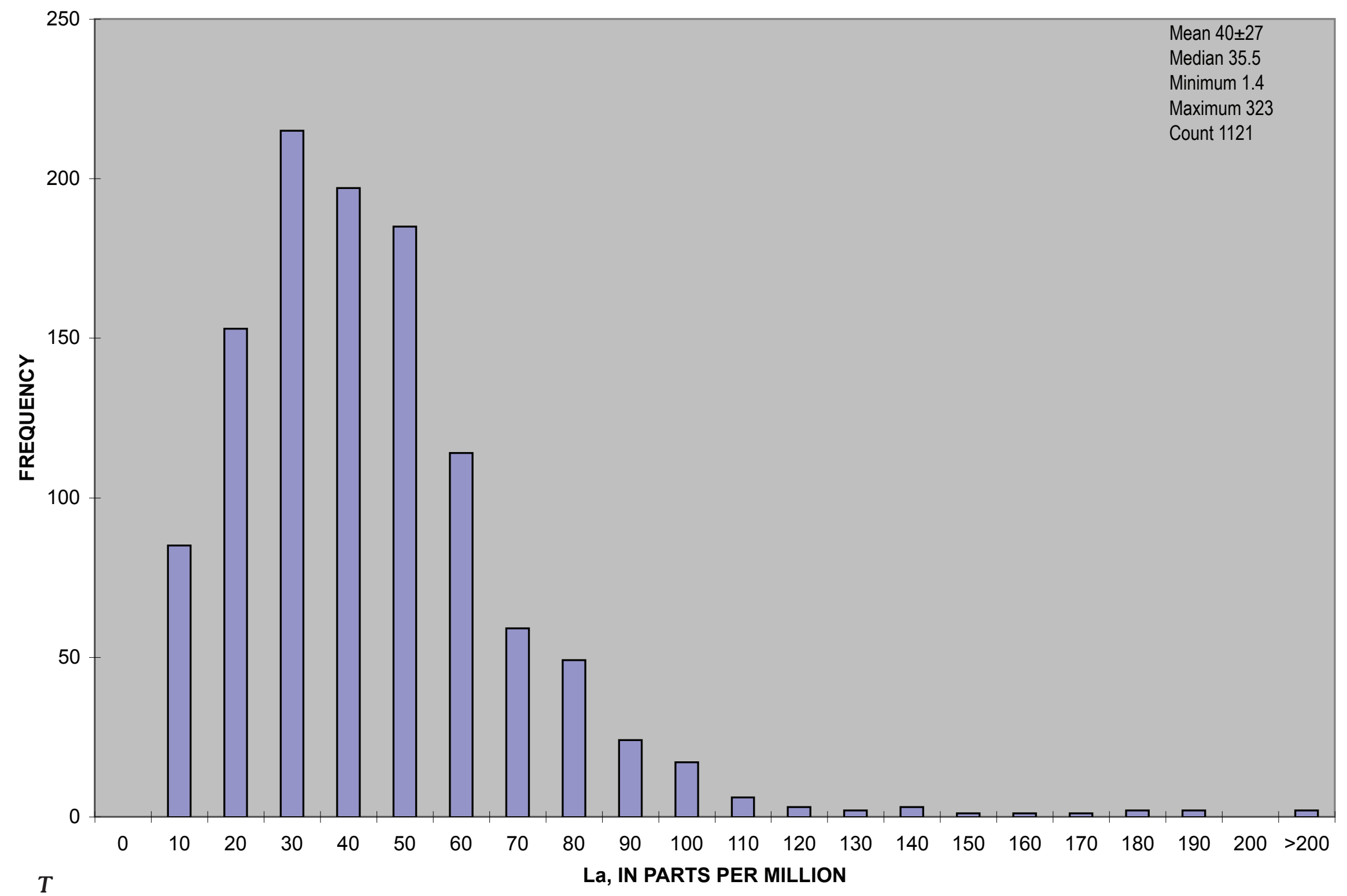

Figure 2. Frequency distribution histograms showing compositions of north-central and northeast Nevada intrusive rock samples—Continued. 


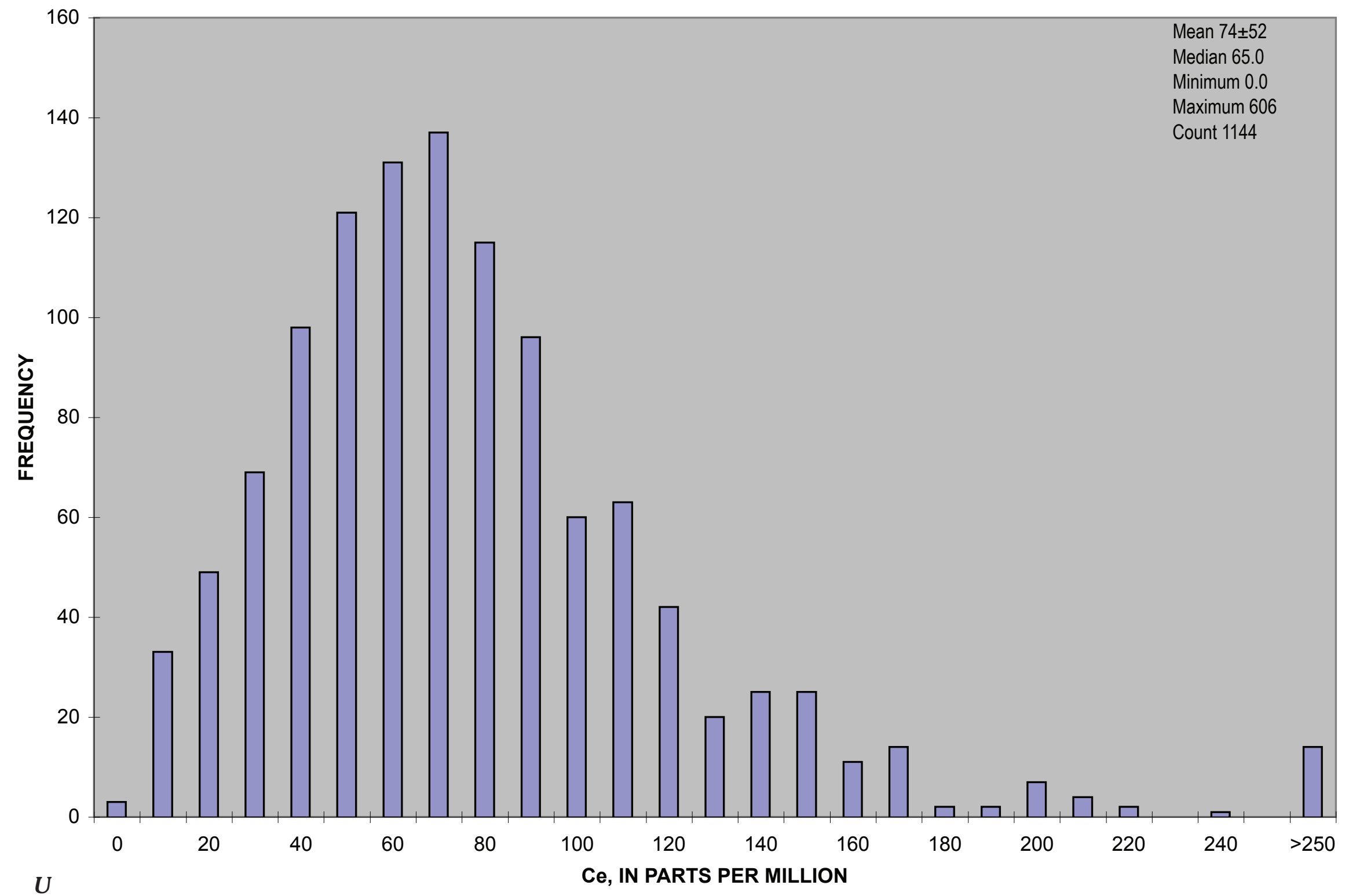

Figure 2. Frequency distribution histograms showing compositions of north-central and northeast Nevada intrusive rock samples—Continued. 


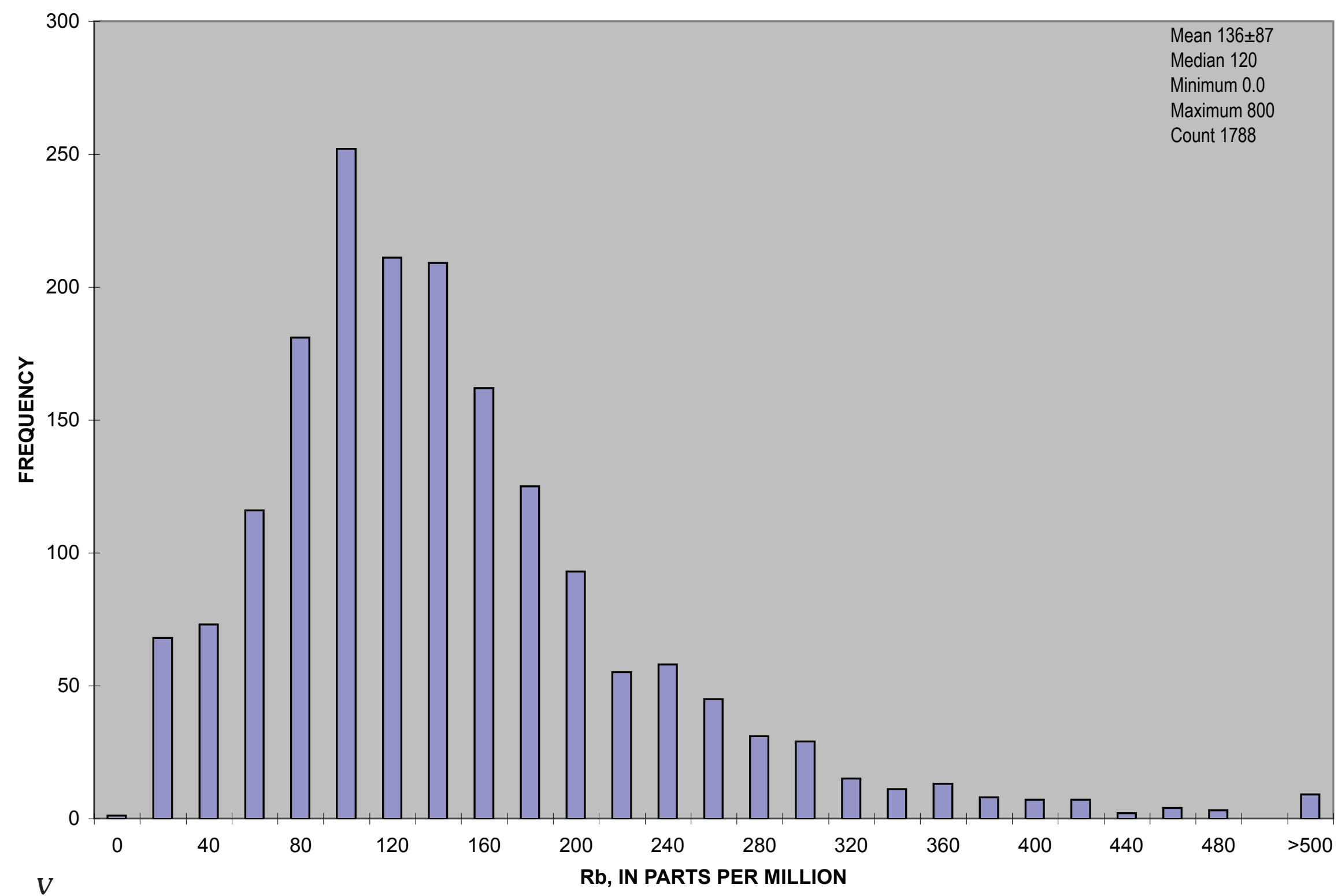

Figure 2. Frequency distribution histograms showing compositions of north-central and northeast Nevada intrusive rock samples-Continued. 


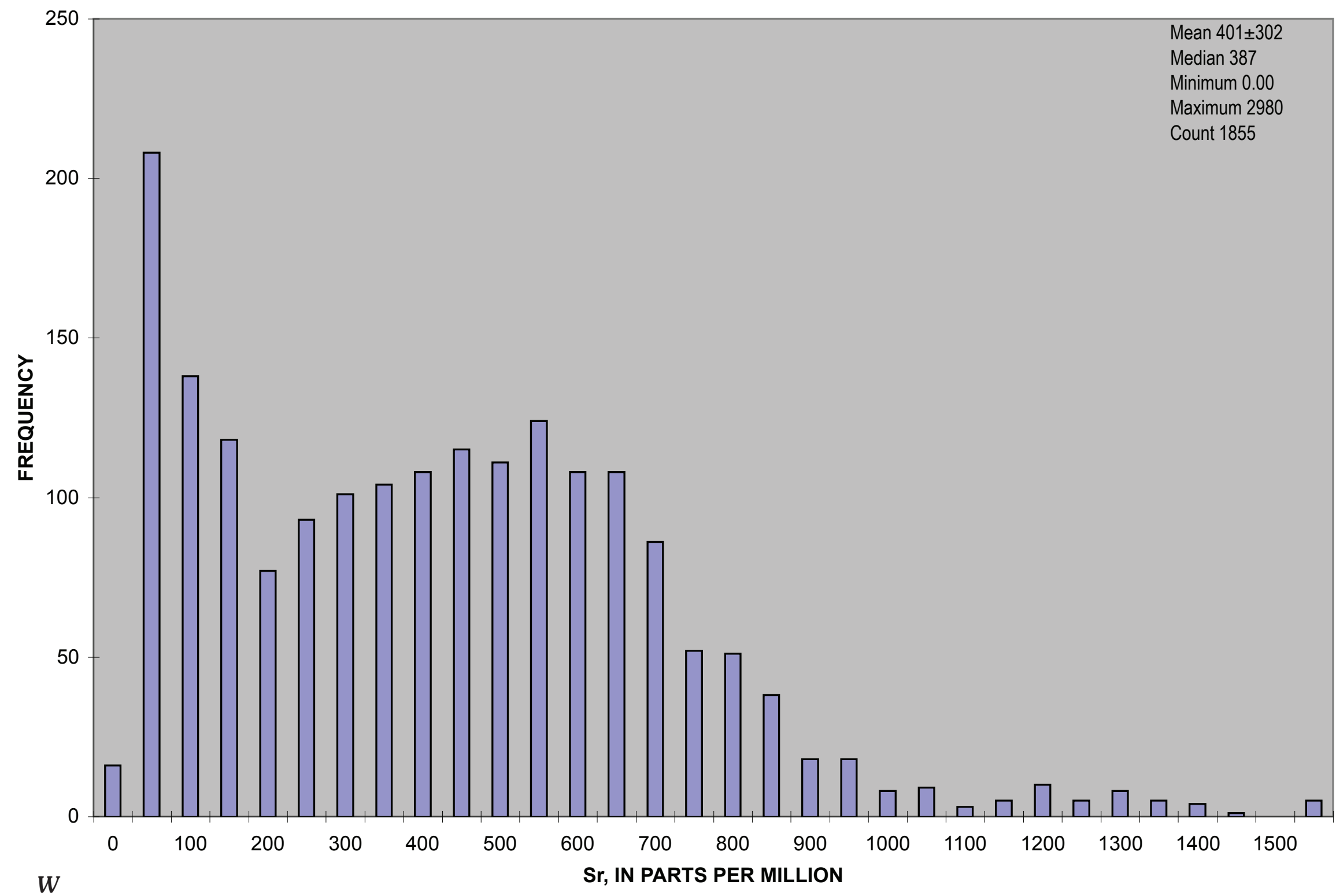

Figure 2. Frequency distribution histograms showing compositions of north-central and northeast Nevada intrusive rock samples-Continued. 


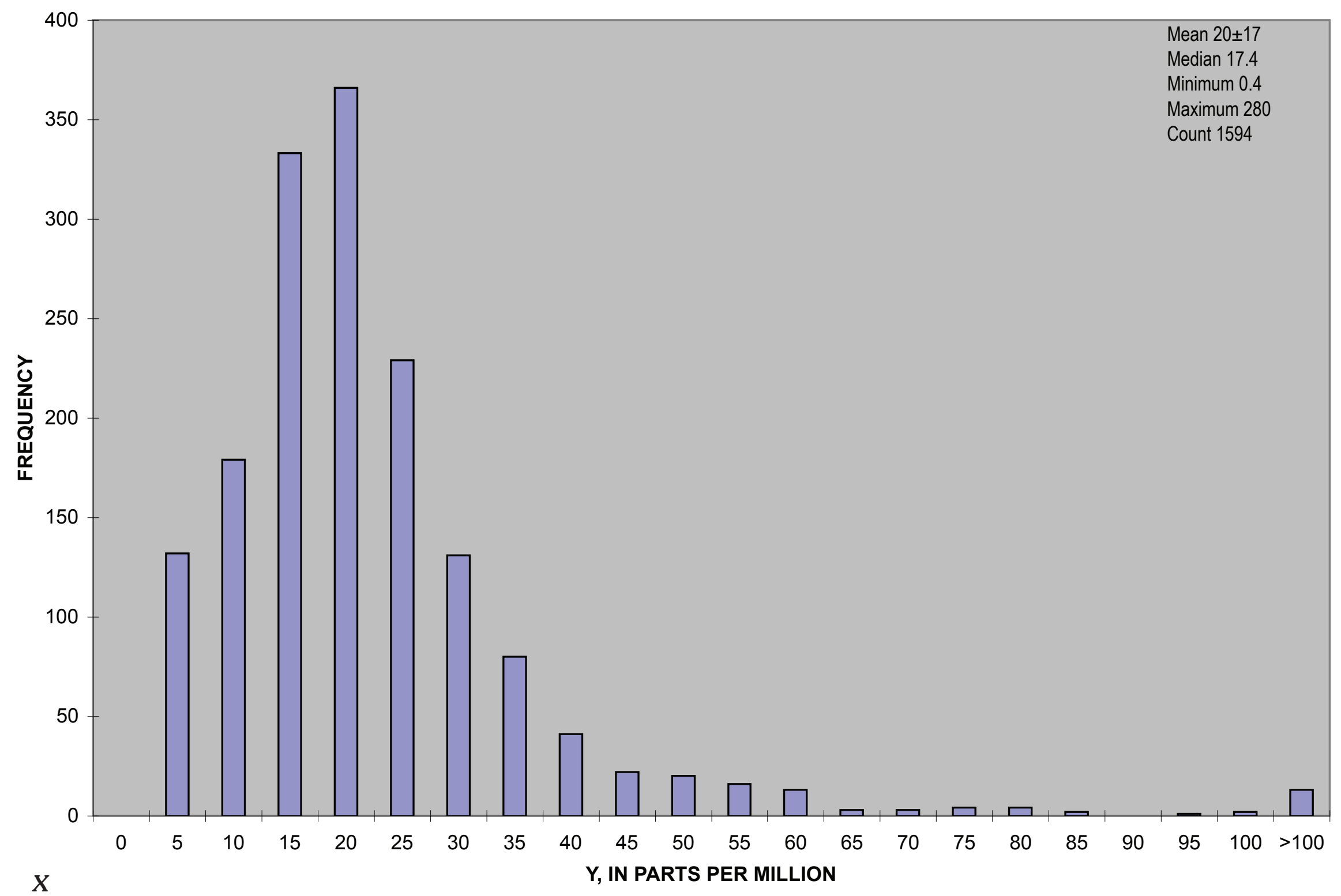

Figure 2. Frequency distribution histograms showing compositions of north-central and northeast Nevada intrusive rock samples-Continued. 


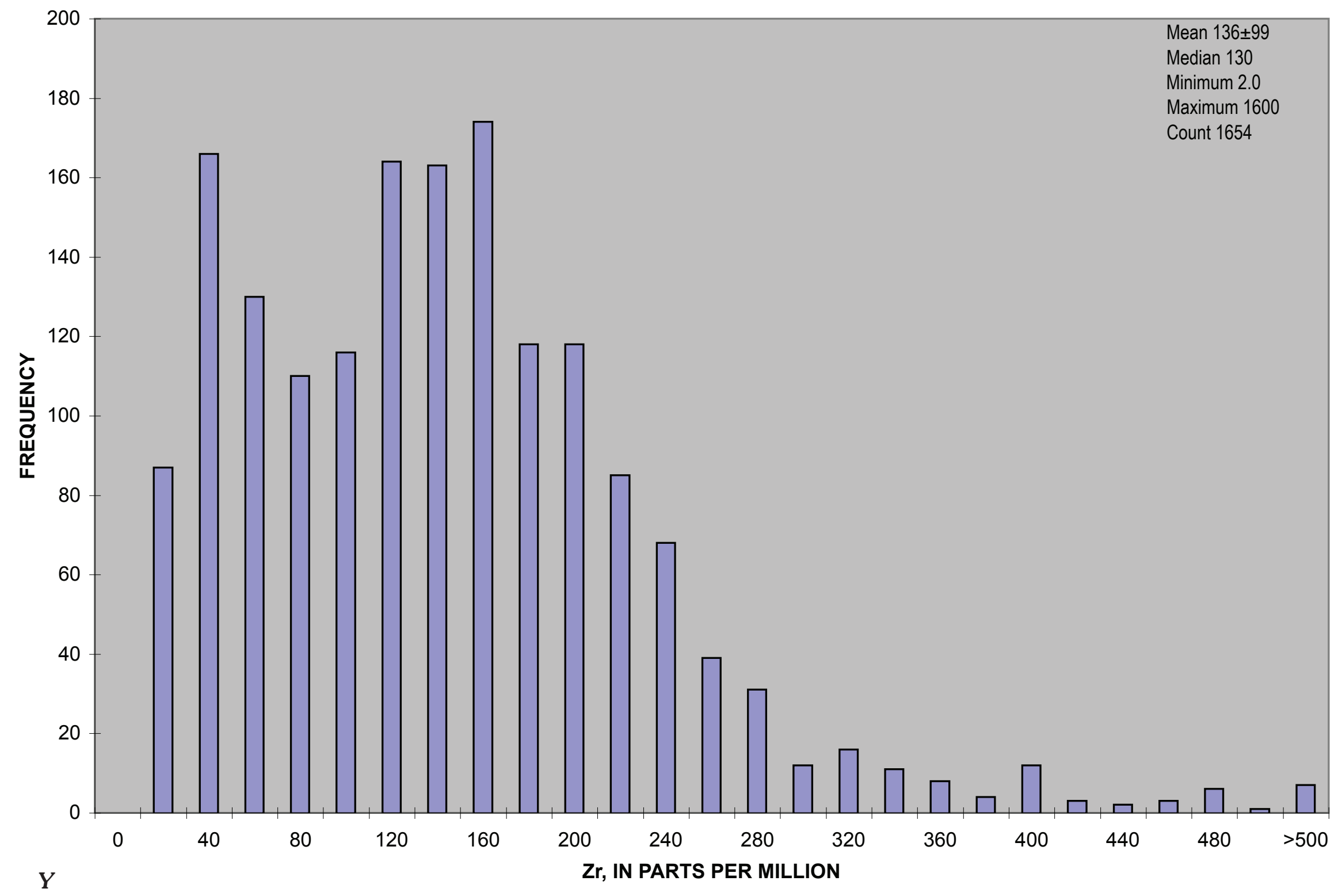

Figure 2. Frequency distribution histograms showing compositions of north-central and northeast Nevada intrusive rock samples—Continued. 


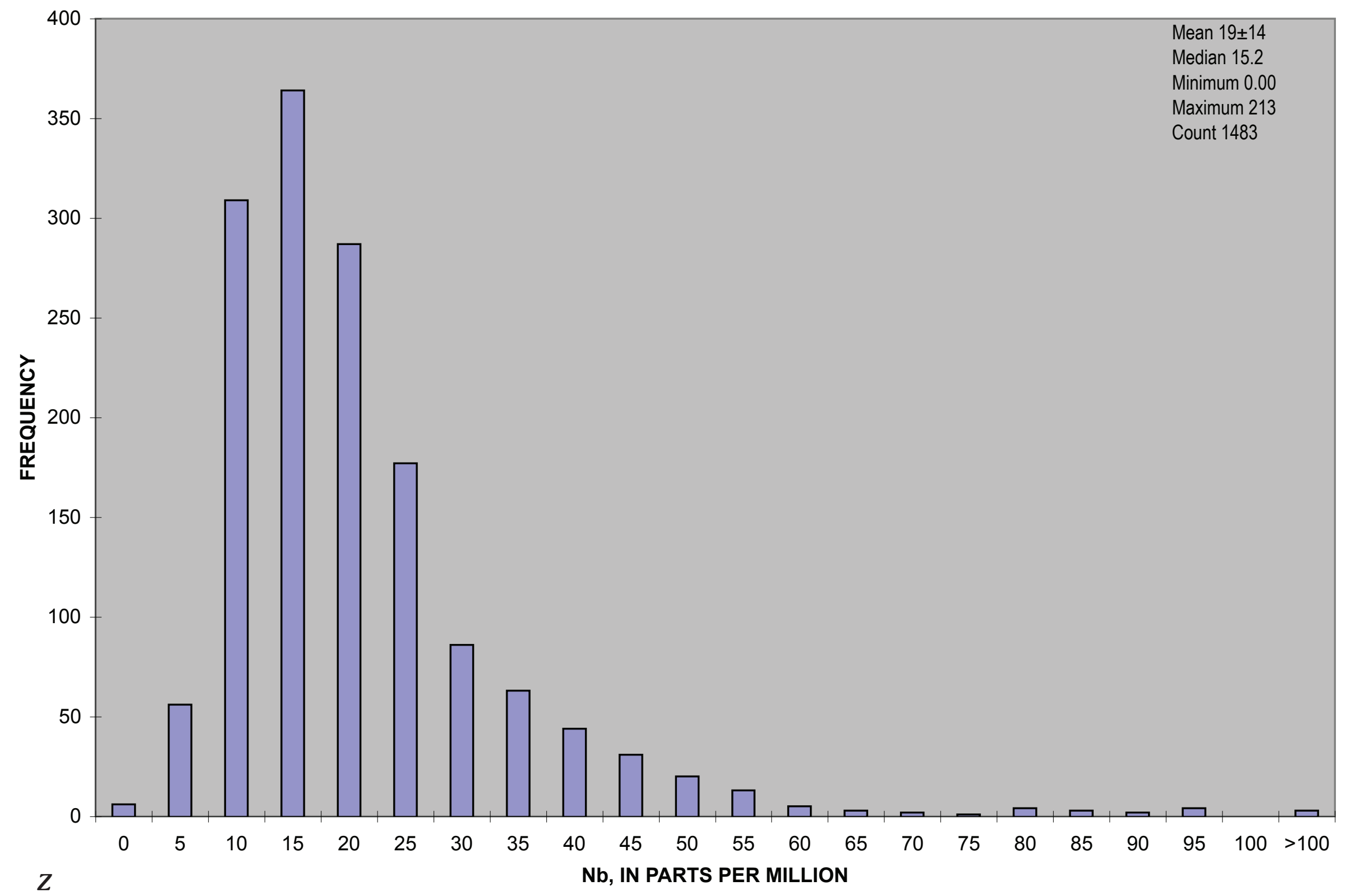

Figure 2. Frequency distribution histograms showing compositions of north-central and northeast Nevada intrusive rock samples—Continued. 


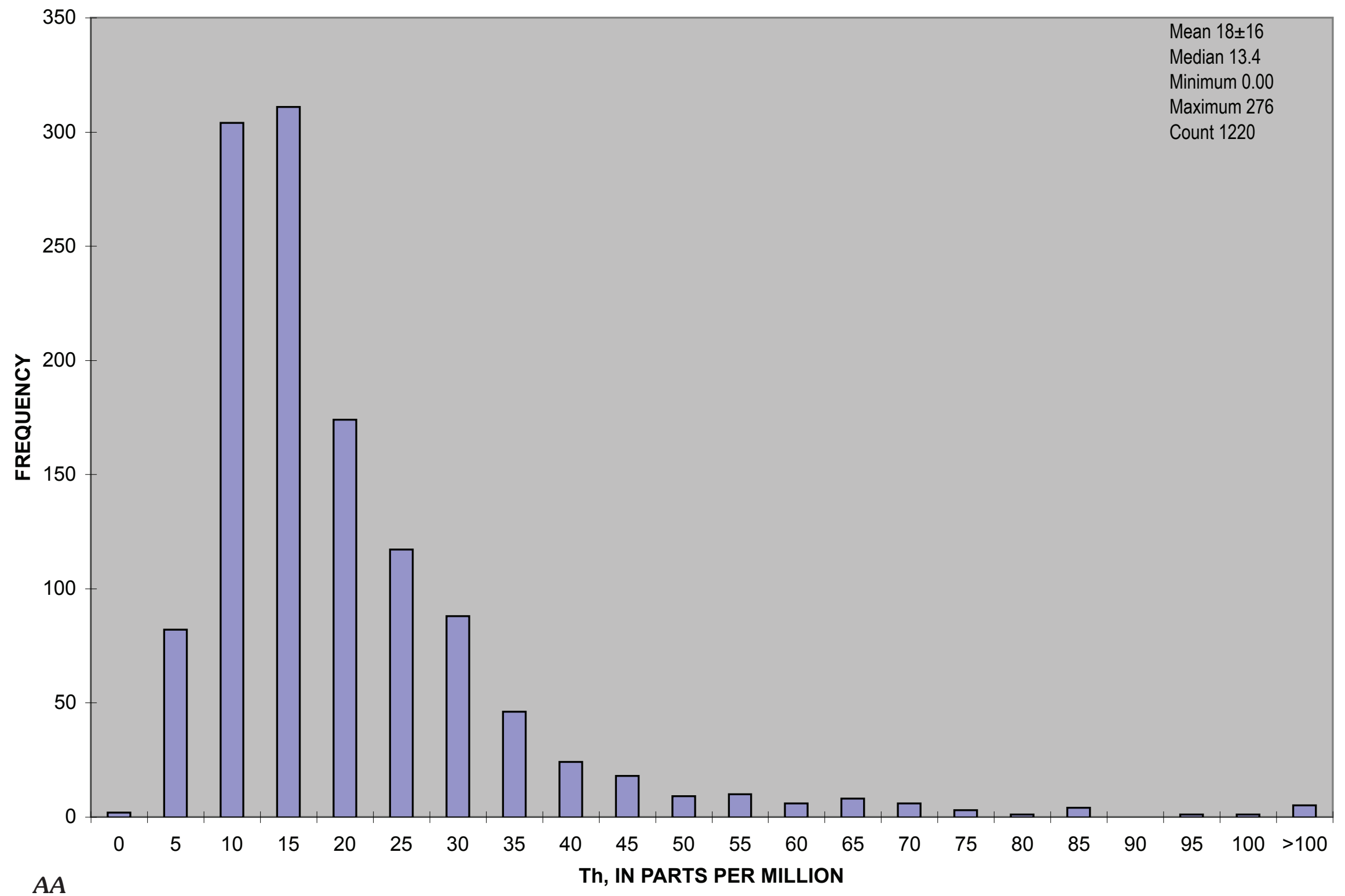

Figure 2. Frequency distribution histograms showing compositions of north-central and northeast Nevada intrusive rock samples—Continued. 


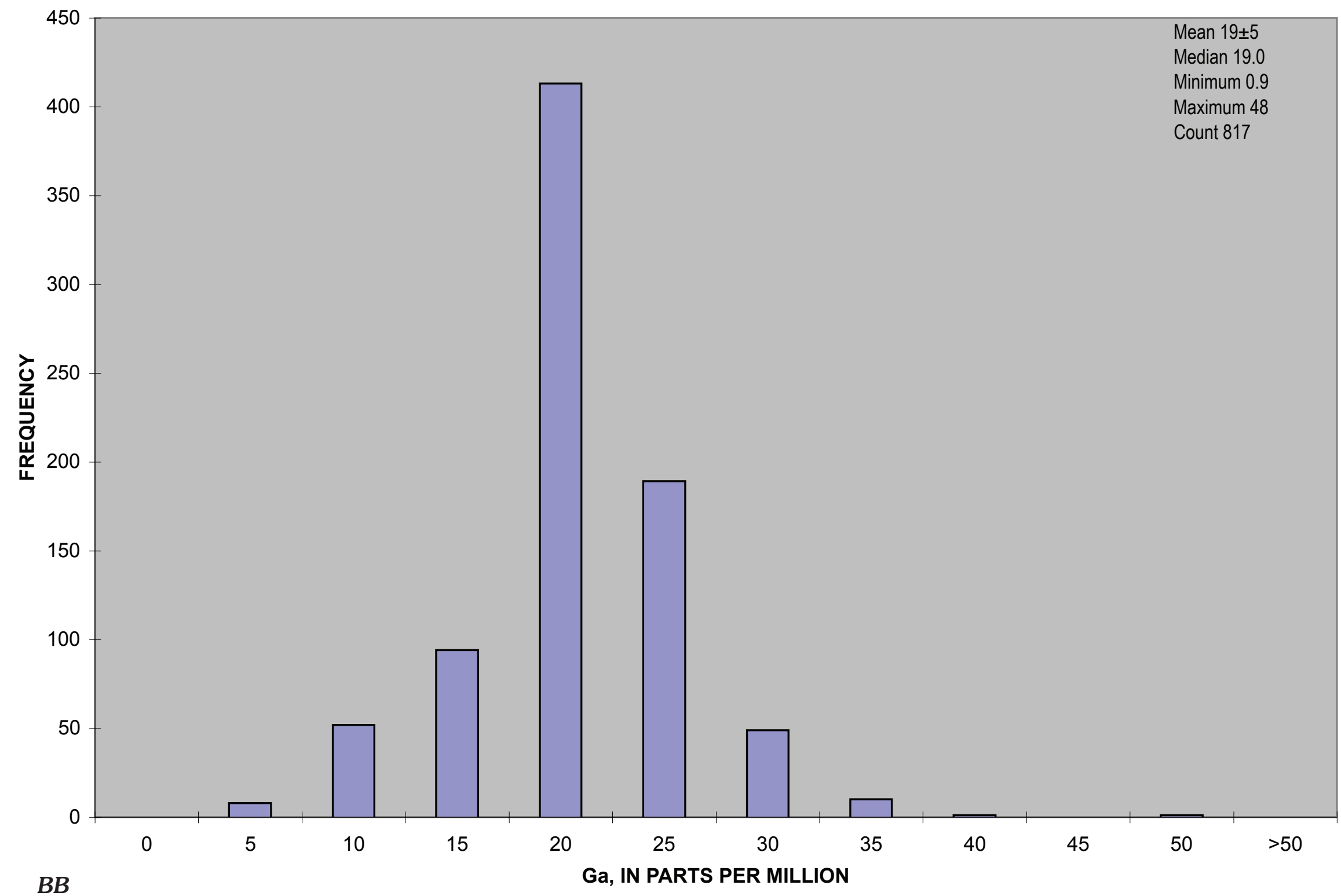

Figure 2. Frequency distribution histograms showing compositions of north-central and northeast Nevada intrusive rock samples—Continued. 


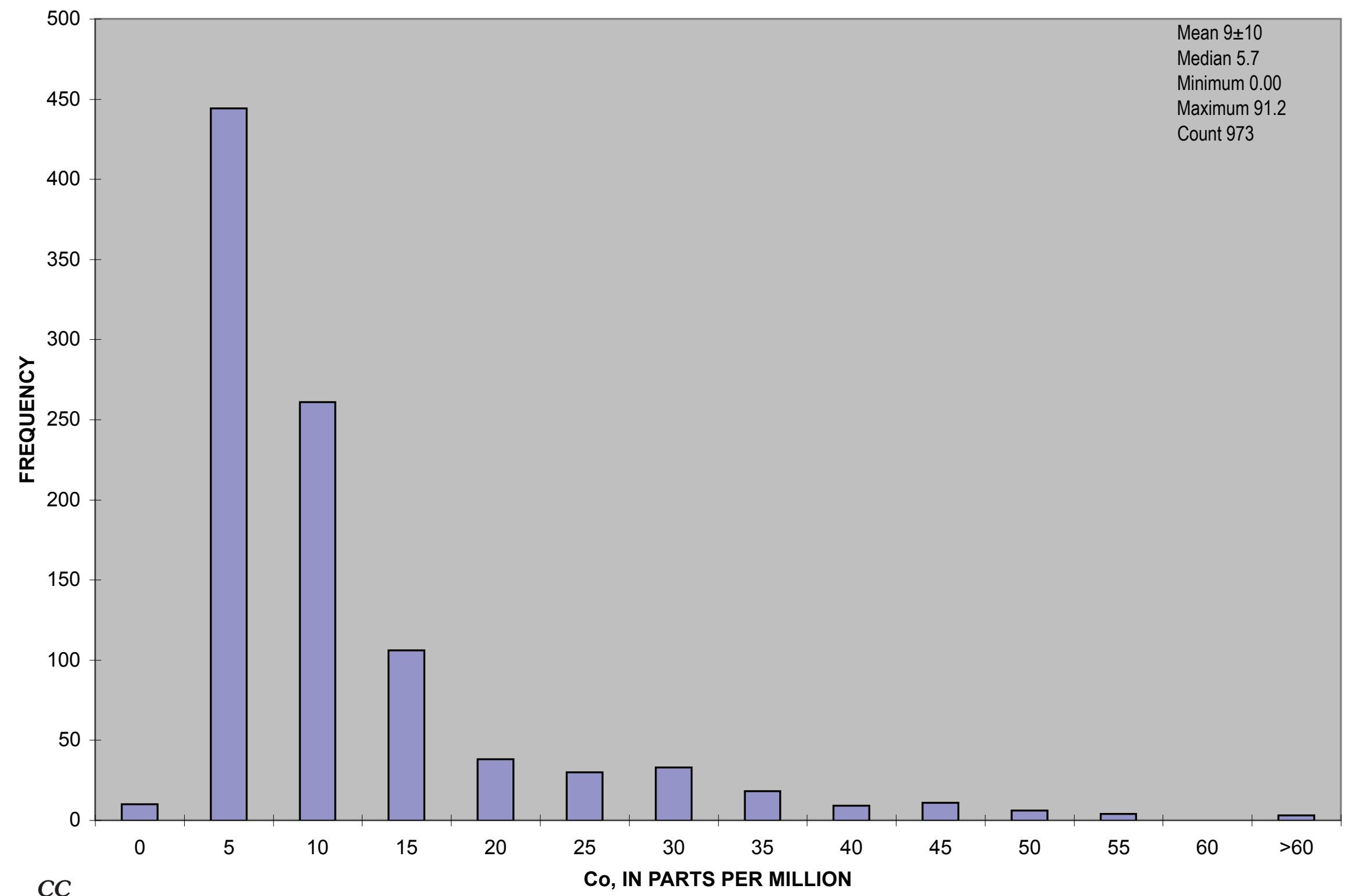

Figure 2. Frequency distribution histograms showing compositions of north-central and northeast Nevada intrusive rock samples—Continued. 


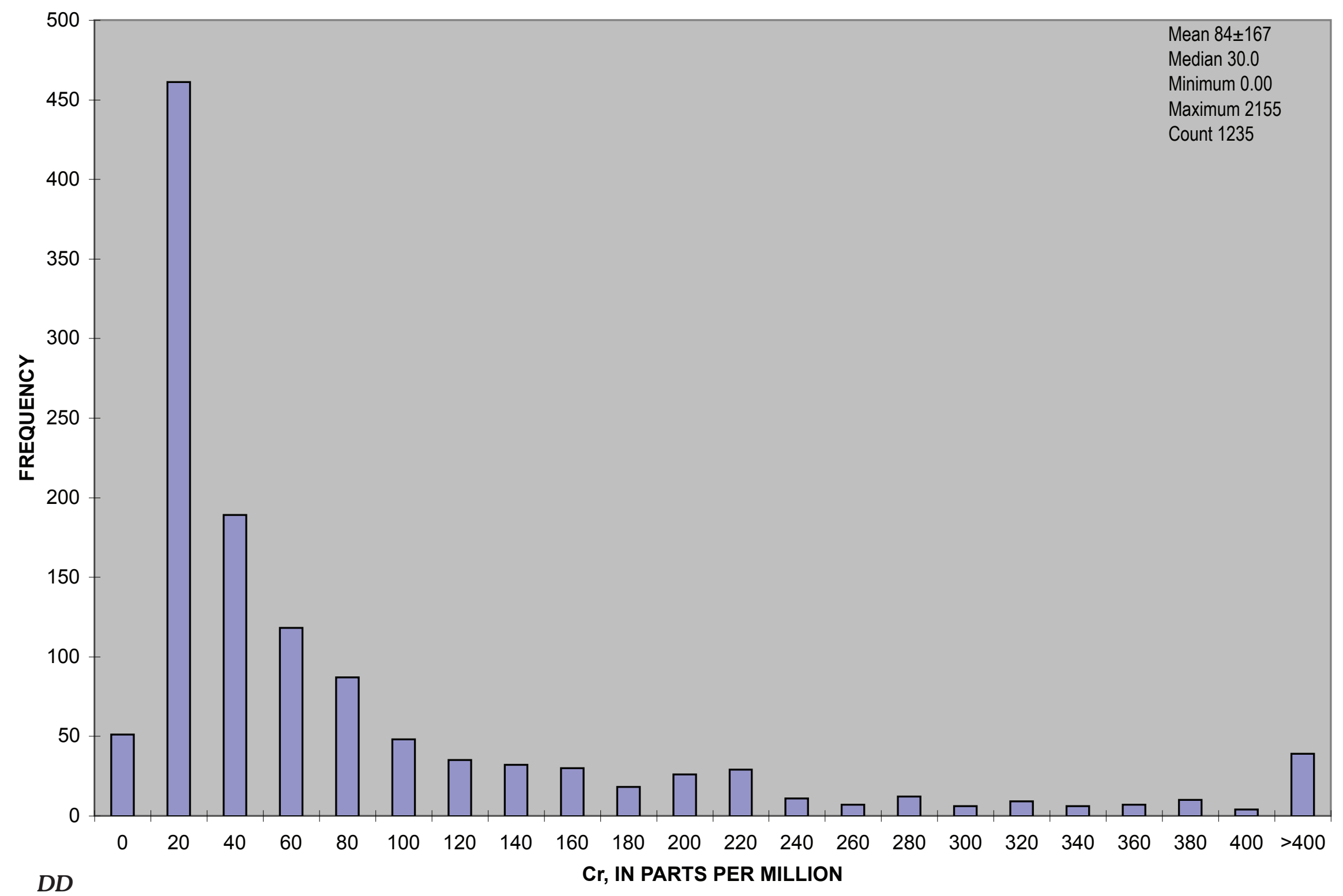

Figure 2. Frequency distribution histograms showing compositions of north-central and northeast Nevada intrusive rock samples—Continued. 


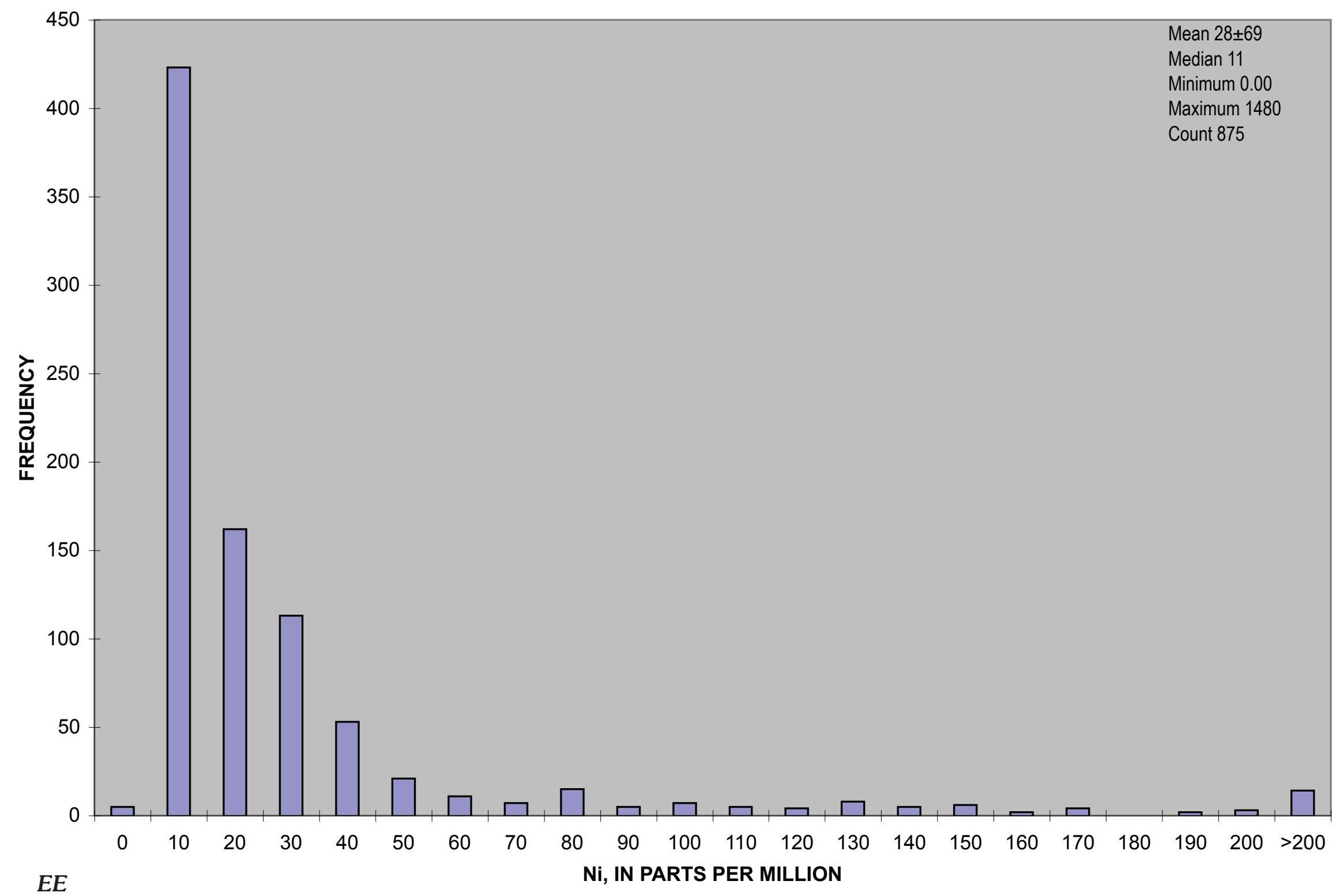

Figure 2. Frequency distribution histograms showing compositions of north-central and northeast Nevada intrusive rock samples—Continued. 


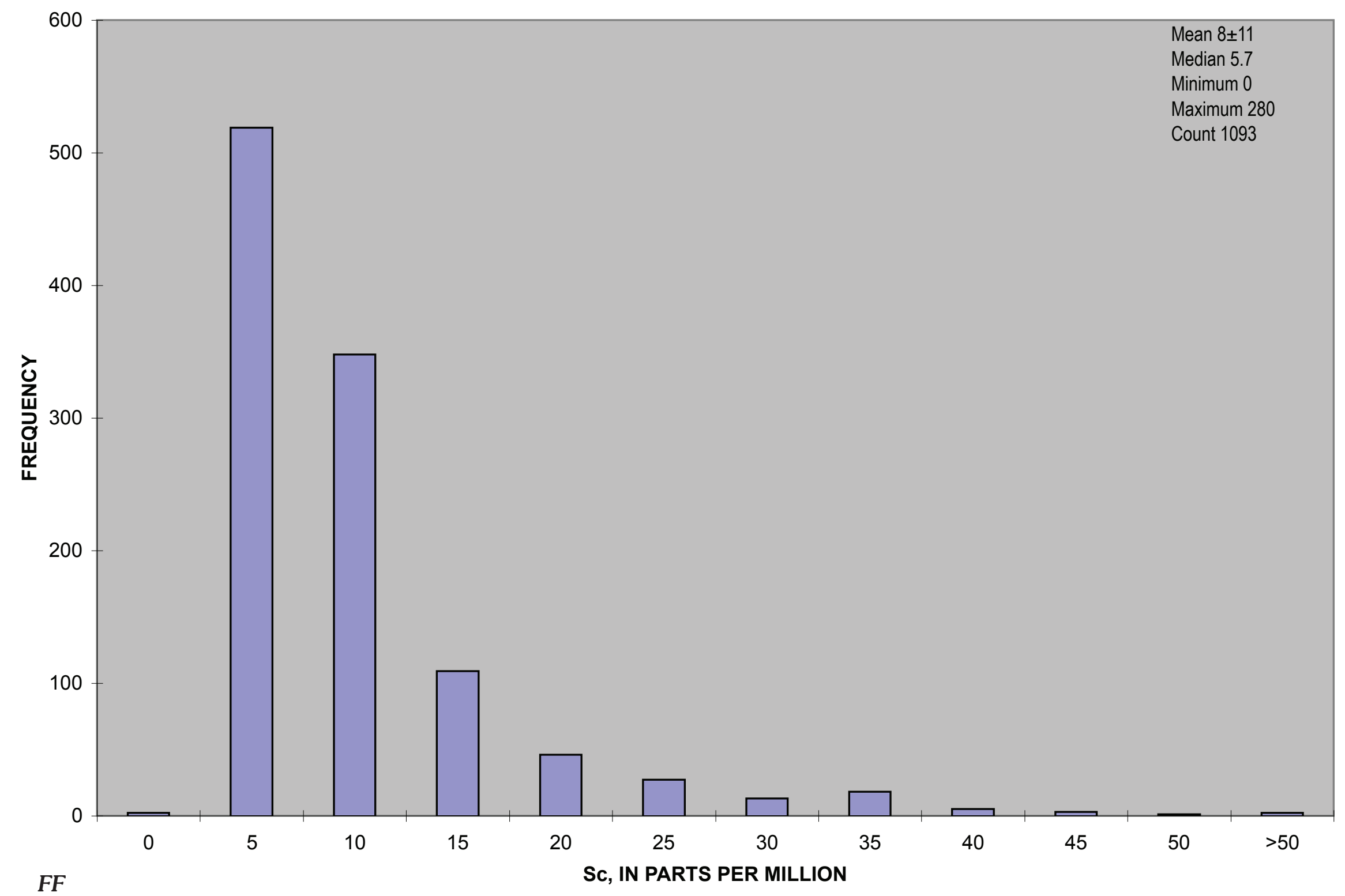

Figure 2. Frequency distribution histograms showing compositions of north-central and northeast Nevada intrusive rock samples—Continued. 


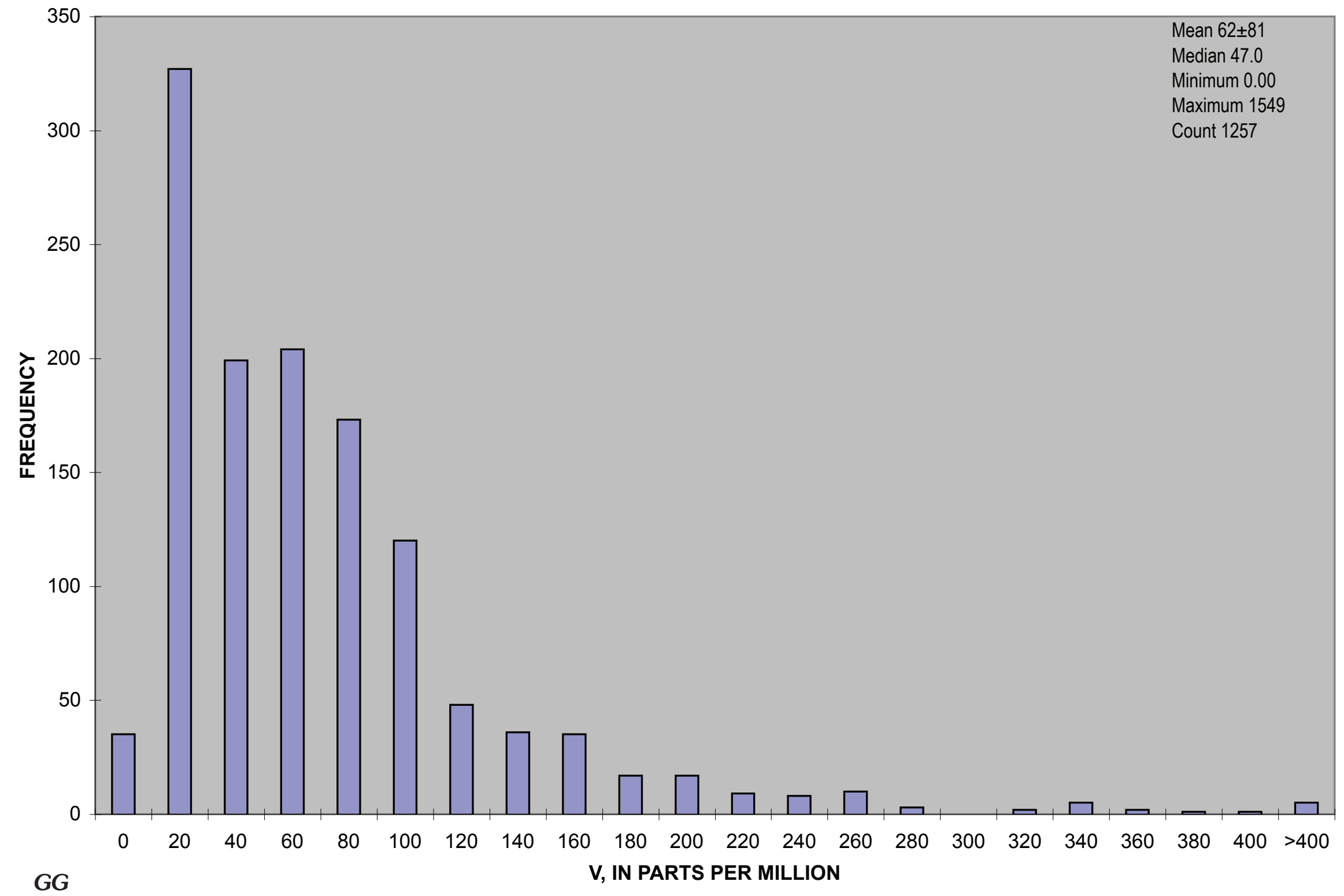

Figure 2. Frequency distribution histograms showing compositions of north-central and northeast Nevada intrusive rock samples—Continued. 


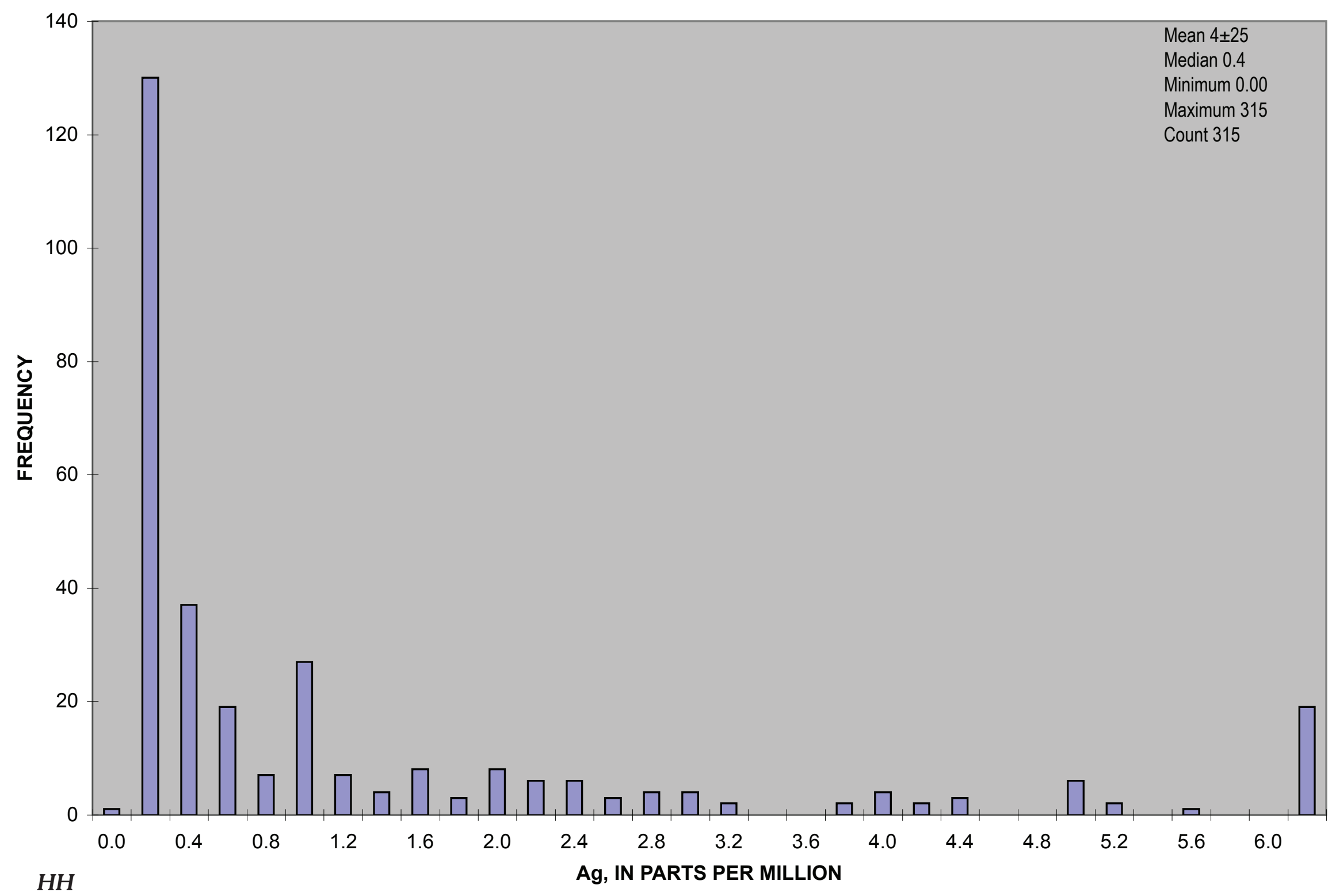

Figure 2. Frequency distribution histograms showing compositions of north-central and northeast Nevada intrusive rock samples—Continued. 


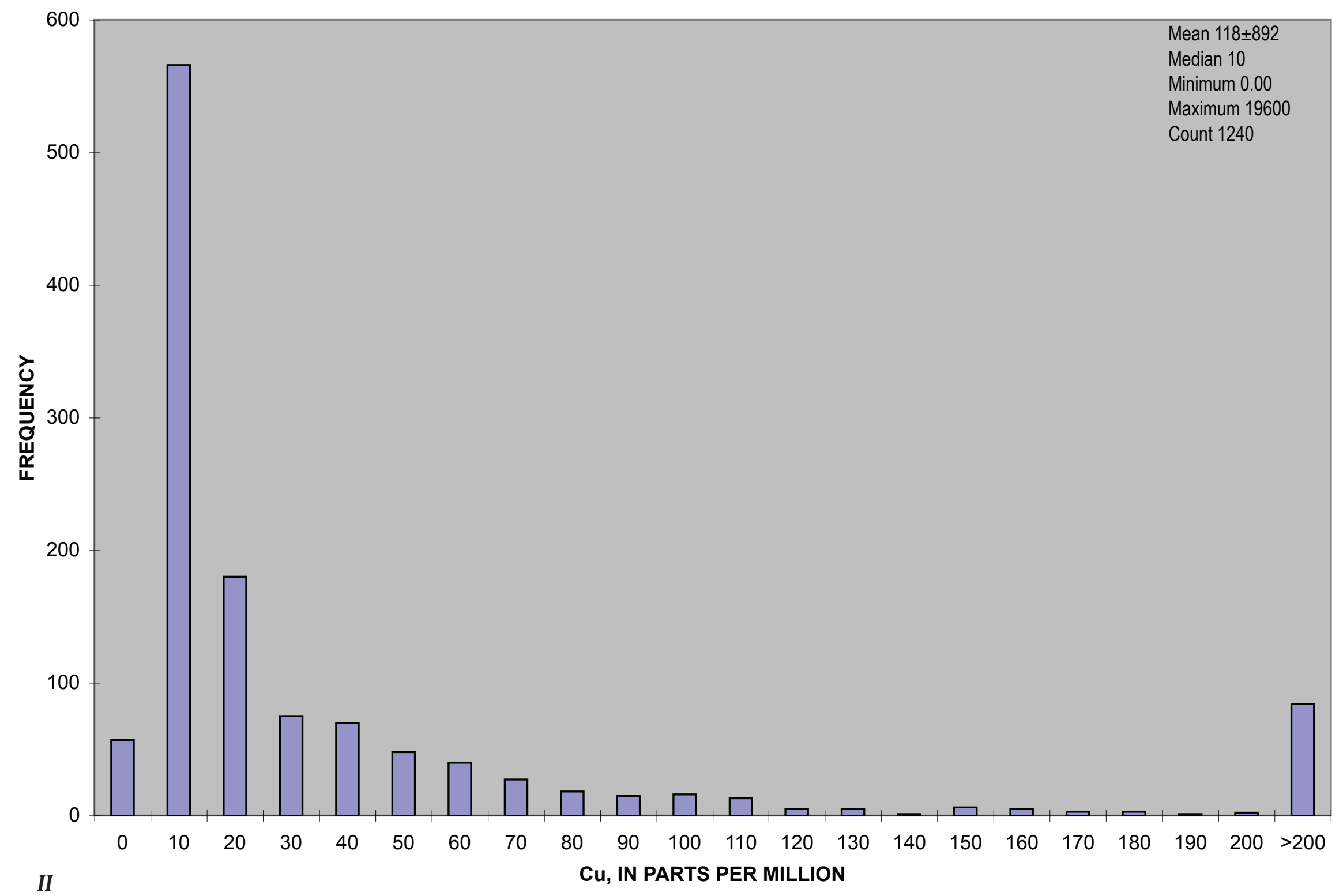

Figure 2. Frequency distribution histograms showing compositions of north-central and northeast Nevada intrusive rock samples—Continued. 


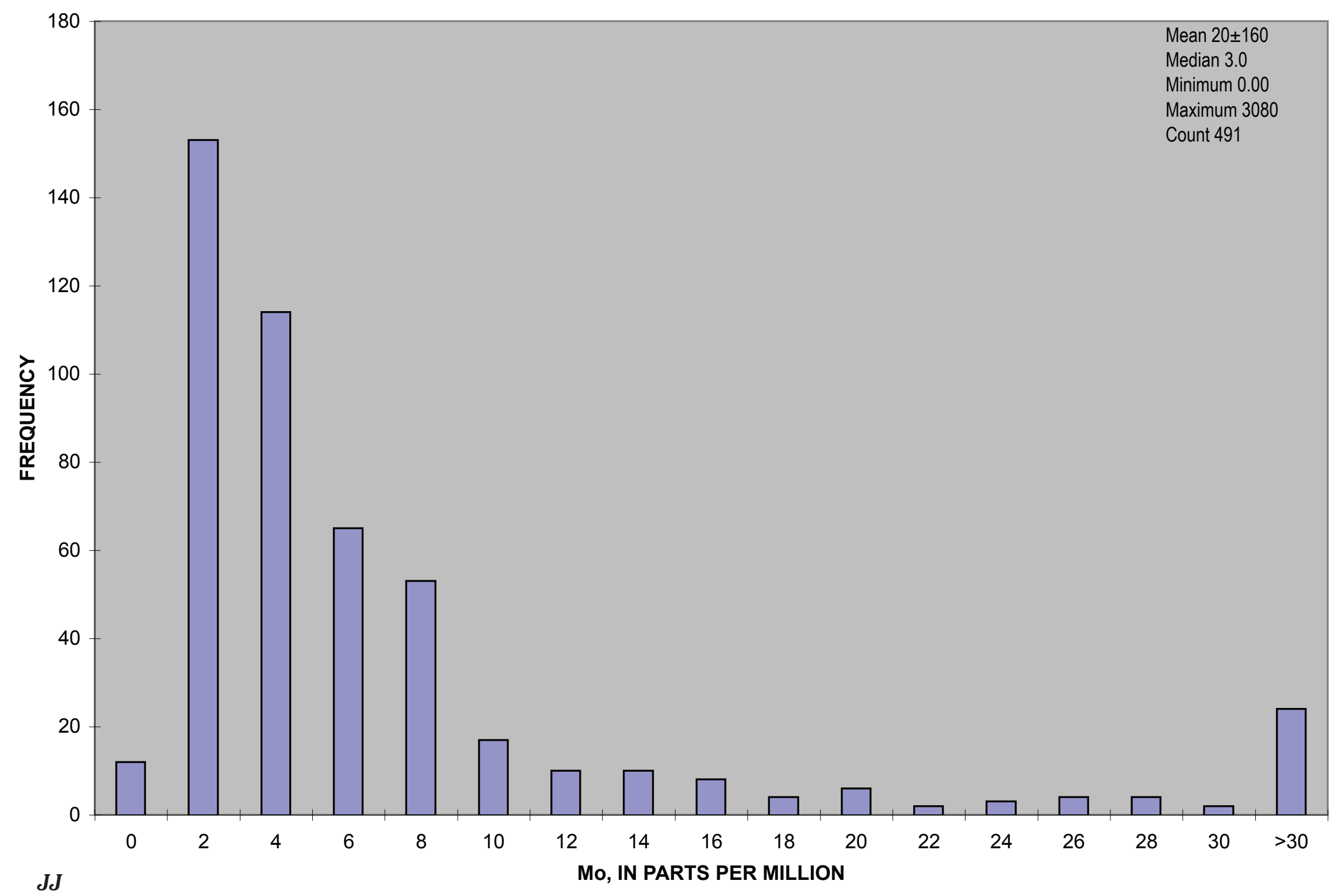

Figure 2. Frequency distribution histograms showing compositions of north-central and northeast Nevada intrusive rock samples—Continued. 


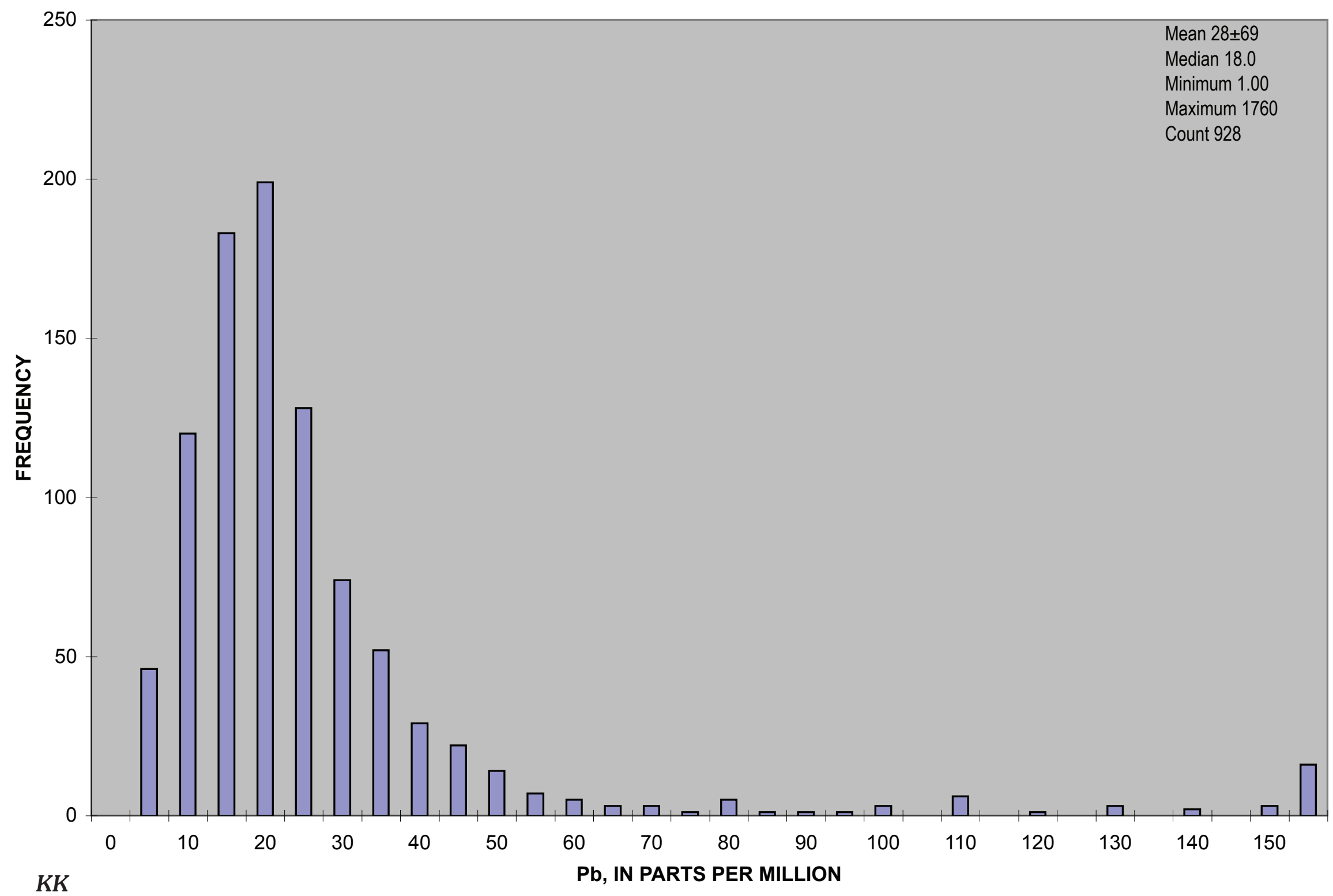

Figure 2. Frequency distribution histograms showing compositions of north-central and northeast Nevada intrusive rock samples—Continued. 


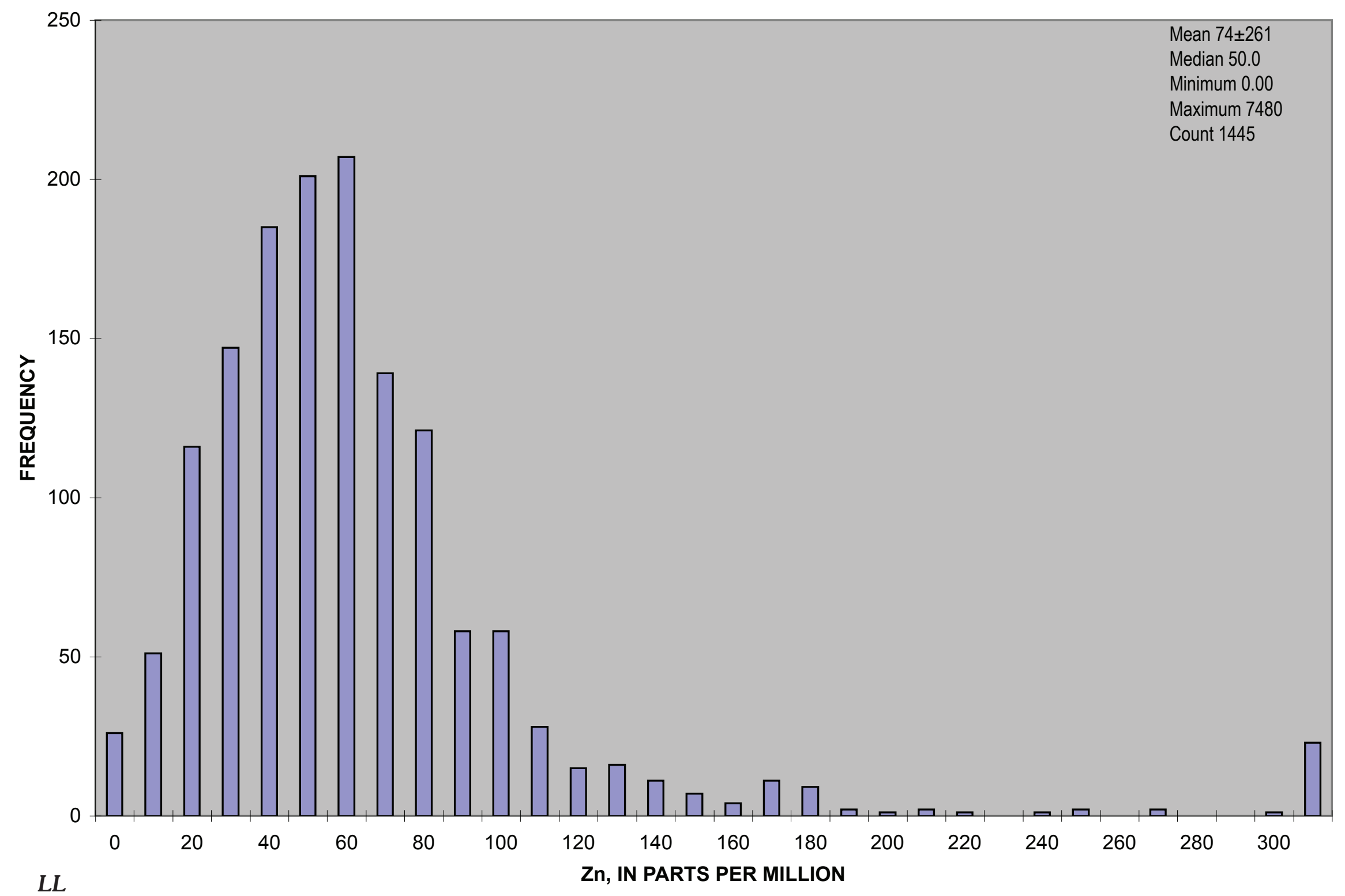

Figure 2. Frequency distribution histograms showing compositions of north-central and northeast Nevada intrusive rock samples—Continued. 


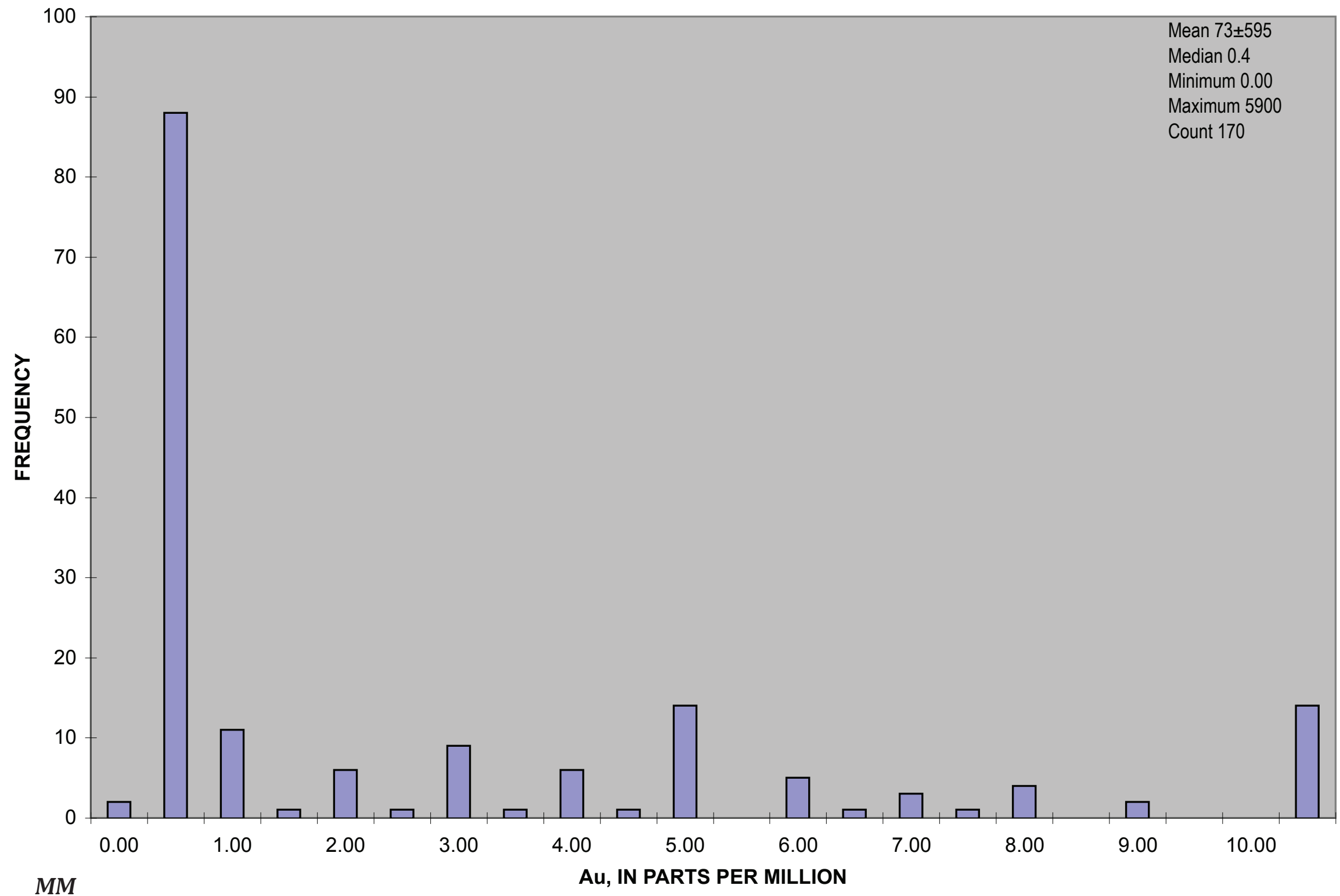

Figure 2. Frequency distribution histograms showing compositions of north-central and northeast Nevada intrusive rock samples—Continued. 
[Each bin denotes an abundance less than or equal to the indicated value but greater than that specified by the bin with the next lowest abundance. $\mathrm{Bins}_{\text {for }} \mathrm{SiO}_{2}, \mathrm{TiO}_{2}, \mathrm{Al}_{2} \mathrm{O}_{3}, \mathrm{FeO}^{*}, \mathrm{MnO}, \mathrm{MgO}, \mathrm{CaO}_{2} \mathrm{Na}_{2} \mathrm{O}$, $\mathrm{K}_{2} \mathrm{O}, \mathrm{P}_{2} \mathrm{O}_{5}, \mathrm{H}_{2} \mathrm{O}+, \mathrm{H}_{2} \mathrm{O}-, \mathrm{CO}_{2}, \mathrm{Cl}, \mathrm{F}, \mathrm{S}$, initial analytical total (total_I), and total volatile content (vol_sum) are in weight percent; all others in parts per million]

\begin{tabular}{|c|c|c|c|c|c|c|c|c|c|c|c|c|c|c|c|c|c|}
\hline \multicolumn{2}{|c|}{$\mathrm{SiO}_{2}$} & \multicolumn{2}{|l|}{$\mathrm{TiO}_{2}$} & \multicolumn{2}{|l|}{$\mathrm{Al}_{2} \mathrm{O}_{3}$} & \multicolumn{2}{|l|}{$\mathrm{FeO} *$} & \multicolumn{2}{|l|}{ Mno } & \multicolumn{2}{|l|}{ MgO } & \multicolumn{2}{|l|}{$\mathrm{CaO}$} & \multicolumn{2}{|l|}{$\mathrm{Na}_{2} \mathrm{O}$} & \multicolumn{2}{|l|}{$\mathrm{K}_{2} \mathrm{O}$} \\
\hline Bin & Freq & Bin & Freq & Bin & Freq & Bin & Freq & Bin & Freq & Bin & Freq & Bin & Freq & Bin & Freq & Bin & Freq \\
\hline 40 & 1 & 0.0 & 21 & 6 & 8 & 0 & 4 & 0.000 & 78 & 0.0 & 8 & 0 & 5 & 0.0 & 23 & 0.0 & 0 \\
\hline 42 & 2 & 0.2 & 682 & 7 & 3 & 1 & 487 & 0.025 & 405 & 0.5 & 1001 & 1 & 667 & 0.5 & 221 & 0.5 & 82 \\
\hline 44 & 5 & 0.4 & 647 & 8 & 6 & 2 & 579 & 0.050 & 550 & 1.0 & 426 & 2 & 476 & 1.0 & 61 & 1.0 & 78 \\
\hline 46 & 11 & 0.6 & 699 & 9 & 8 & 3 & 575 & 0.075 & 644 & 1.5 & 354 & 3 & 433 & 1.5 & 61 & 1.5 & 78 \\
\hline 48 & 10 & 0.8 & 340 & 10 & 15 & 4 & 453 & 0.100 & 353 & 2.0 & 329 & 4 & 423 & 2.0 & 82 & 2.0 & 73 \\
\hline 50 & 29 & 1.0 & 168 & 11 & 29 & 5 & 226 & 0.125 & 199 & 2.5 & 202 & 5 & 296 & 2.5 & 137 & 2.5 & 172 \\
\hline 52 & 32 & 1.2 & 94 & 12 & 38 & 6 & 197 & 0.150 & 95 & 3.0 & 137 & 6 & 185 & 3.0 & 323 & 3.0 & 281 \\
\hline 54 & 40 & 1.4 & 54 & 13 & 142 & 7 & 113 & 0.175 & 52 & 3.5 & 72 & 7 & 98 & 3.5 & 706 & 3.5 & 392 \\
\hline 56 & 60 & 1.6 & 27 & 14 & 367 & 8 & 65 & 0.200 & 31 & 4.0 & 47 & 8 & 53 & 4.0 & 677 & 4.0 & 363 \\
\hline 58 & 58 & 1.8 & 18 & 15 & 621 & 9 & 40 & 0.225 & 19 & 4.5 & 49 & 9 & 38 & 4.5 & 288 & 4.5 & 500 \\
\hline 60 & 68 & 2.0 & 14 & 16 & 663 & 10 & 24 & 0.250 & 11 & 5.0 & 29 & 10 & 36 & 5.0 & 166 & 5.0 & 357 \\
\hline 62 & 103 & 2.2 & 6 & 17 & 488 & 11 & 23 & 0.275 & 7 & 5.5 & 27 & 11 & 23 & 5.5 & 36 & 5.5 & 201 \\
\hline 64 & 132 & 2.4 & 14 & 18 & 273 & 12 & 20 & 0.300 & 4 & 6.0 & 23 & 12 & 10 & 6.0 & 17 & 6.0 & 85 \\
\hline 66 & 216 & 2.6 & 6 & 19 & 71 & 13 & 8 & 0.325 & 5 & 6.5 & 17 & 13 & 15 & 6.5 & 9 & 6.5 & 60 \\
\hline 68 & 300 & 2.8 & 0 & 20 & 34 & 14 & 6 & 0.350 & 3 & 7.0 & 16 & 14 & 12 & 7.0 & 12 & 7.0 & 35 \\
\hline 70 & 293 & 3.0 & 0 & 21 & 18 & 15 & 3 & 0.375 & 0 & 7.5 & 11 & 15 & 4 & 7.5 & 1 & 7.5 & 22 \\
\hline 72 & 339 & $>3.0$ & 11 & 22 & 6 & $>15$ & 16 & 0.400 & 3 & 8.0 & 11 & $>15$ & 30 & 8.0 & 4 & 8.0 & 22 \\
\hline 74 & 328 & & & 23 & 20 & & & 0.425 & 2 & 8.5 & 4 & & & $>8.0$ & 7 & 8.5 & 11 \\
\hline 76 & 366 & & & 24 & 7 & & & 0.450 & 1 & 9.0 & 4 & & & & & 9.0 & 7 \\
\hline 78 & 274 & & & 25 & 6 & & & 0.475 & 0 & 9.5 & 6 & & & & & 9.5 & 4 \\
\hline 80 & 83 & & & $>25$ & 17 & & & 0.500 & 1 & 10.0 & 6 & & & & & 10.0 & 4 \\
\hline 82 & 59 & & & & & & & $>0.500$ & 6 & 10.5 & 4 & & & & & $>10.0$ & 12 \\
\hline 84 & 11 & & & & & & & & & 11.0 & 3 & & & & & & \\
\hline 86 & 12 & & & & & & & & & $>11.0$ & 21 & & & & & & \\
\hline 88 & 3 & & & & & & & & & & & & & & & & \\
\hline 90 & 3 & & & & & & & & & & & & & & & & \\
\hline$>90$ & 2 & & & & & & & & & & & & & & & & \\
\hline
\end{tabular}


Table 1. Number of observations (Freq) within each composition range (Bin) for north-central and northeast Nevada intrusion database-Continued.

\begin{tabular}{|c|c|c|c|c|c|c|c|c|c|c|c|c|c|c|c|c|c|}
\hline \multicolumn{2}{|l|}{$\mathbf{P}_{2} \mathbf{O}_{5}$} & \multicolumn{2}{|l|}{$\mathrm{H}_{2} \mathrm{O}^{+}$} & \multicolumn{2}{|l|}{$\mathrm{H}_{2} \mathrm{O}^{-}$} & \multicolumn{2}{|l|}{$\mathrm{CO}_{2}$} & \multicolumn{2}{|l|}{ Cl } & \multicolumn{2}{|l|}{$\mathbf{F}$} & \multicolumn{2}{|l|}{$\mathbf{s}$} & \multicolumn{2}{|l|}{ total_I } & \multicolumn{2}{|c|}{ vol_sum } \\
\hline Bin & Freq & Bin & Freq & Bin & Freq & Bin & Freq & Bin & Freq & Bin & Freq & Bin & Freq & Bin & Freq & Bin & Freq \\
\hline 0.00 & 62 & 0.00 & 0 & 0.00 & 2 & 0.00 & 9 & 0.000 & 58 & 0.00 & 0 & 0.00 & 18 & 85 & 11 & 0.0 & 52 \\
\hline 0.05 & 317 & 0.25 & 41 & 0.10 & 255 & 0.10 & 369 & 0.010 & 88 & 0.02 & 52 & 0.01 & 264 & 86 & 3 & 0.5 & 691 \\
\hline 0.10 & 428 & 0.50 & 173 & 0.20 & 287 & 0.20 & 89 & 0.020 & 53 & 0.04 & 126 & 0.02 & 37 & 87 & 4 & 1.0 & 811 \\
\hline 0.15 & 428 & 0.75 & 233 & 0.30 & 96 & 0.30 & 47 & 0.030 & 34 & 0.06 & 142 & 0.03 & 9 & 88 & 4 & 1.5 & 312 \\
\hline 0.20 & 388 & 1.00 & 169 & 0.40 & 57 & 0.40 & 34 & 0.040 & 9 & 0.08 & 140 & 0.04 & 15 & 89 & 6 & 2.0 & 147 \\
\hline 0.25 & 328 & 1.25 & 72 & 0.50 & 29 & 0.50 & 24 & 0.050 & 8 & 0.10 & 68 & 0.05 & 6 & 90 & 5 & 2.5 & 95 \\
\hline 0.30 & 199 & 1.50 & 60 & 0.60 & 32 & 0.60 & 16 & 0.060 & 2 & 0.12 & 37 & 0.06 & 6 & 91 & 9 & 3.0 & 76 \\
\hline 0.35 & 140 & 1.75 & 27 & 0.70 & 15 & 0.70 & 13 & 0.070 & 1 & 0.14 & 31 & 0.07 & 7 & 92 & 10 & 3.5 & 60 \\
\hline 0.40 & 72 & 2.00 & 30 & 0.80 & 13 & 0.80 & 11 & 0.080 & 1 & 0.16 & 18 & 0.08 & 7 & 93 & 18 & 4.0 & 47 \\
\hline 0.45 & 34 & 2.25 & 18 & 0.90 & 15 & 0.90 & 8 & 0.090 & 0 & 0.18 & 12 & 0.09 & 5 & 94 & 28 & 4.5 & 30 \\
\hline 0.50 & 36 & 2.50 & 20 & 1.00 & 11 & 1.00 & 11 & 0.100 & 0 & 0.20 & 10 & 0.10 & 3 & 95 & 26 & 5.0 & 41 \\
\hline 0.55 & 26 & 2.75 & 11 & 1.10 & 9 & 1.10 & 1 & $>0.100$ & 9 & 0.22 & 5 & 0.11 & 2 & 96 & 27 & 5.5 & 33 \\
\hline 0.60 & 14 & 3.00 & 10 & 1.20 & 4 & 1.20 & 9 & & & 0.24 & 5 & 0.12 & 2 & 97 & 65 & 6.0 & 14 \\
\hline 0.65 & 13 & 3.25 & 8 & 1.30 & 4 & 1.30 & 1 & & & 0.26 & 4 & 0.13 & 4 & 98 & 108 & 6.5 & 20 \\
\hline 0.70 & 10 & 3.50 & 7 & 1.40 & 5 & 1.40 & 0 & & & 0.28 & 3 & 0.14 & 2 & 99 & 423 & 7.0 & 16 \\
\hline 0.75 & 12 & 3.75 & 9 & 1.50 & 3 & 1.50 & 0 & & & 0.30 & 0 & 0.15 & 3 & 100 & 1399 & 7.5 & 15 \\
\hline 0.80 & 4 & 4.00 & 3 & 1.60 & 5 & 1.60 & 2 & & & 0.32 & 2 & 0.16 & 1 & 101 & 591 & 8.0 & 15 \\
\hline 0.85 & 5 & 4.25 & 7 & 1.70 & 1 & 1.70 & 5 & & & 0.34 & 0 & 0.17 & 6 & 102 & 56 & 8.5 & 7 \\
\hline 0.90 & 5 & 4.50 & 2 & 1.80 & 3 & 1.80 & 5 & & & 0.36 & 4 & 0.18 & 2 & 103 & 18 & 9.0 & 16 \\
\hline 0.95 & 1 & 4.75 & 2 & 1.90 & 2 & 1.90 & 1 & & & 0.38 & 1 & 0.19 & 2 & 104 & 13 & 9.5 & 9 \\
\hline$>0.95$ & 17 & 5.00 & 4 & 2.00 & 1 & 2.00 & 3 & & & 0.40 & 1 & 0.20 & 1 & 105 & 7 & 10.0 & 4 \\
\hline & & 5.25 & 2 & $>2.00$ & 8 & $>2.00$ & 40 & & & 0.42 & 0 & 0.21 & 2 & 106 & 2 & $>10.0$ & 68 \\
\hline & & 5.50 & 3 & & & & & & & 0.44 & 3 & 0.22 & 1 & 107 & 4 & & \\
\hline & & 5.75 & 0 & & & & & & & 0.46 & 1 & 0.23 & 1 & 108 & 3 & & \\
\hline & & 6.00 & 1 & & & & & & & 0.48 & 0 & 0.24 & 1 & $>108$ & 0 & & \\
\hline & & $>6.00$ & 3 & & & & & & & 0.50 & 1 & 0.25 & 0 & & & & \\
\hline & & & & & & & & & & $>0.50$ & 14 & 0.26 & 2 & & & & \\
\hline & & & & & & & & & & & & 0.27 & 1 & & & & \\
\hline & & & & & & & & & & & & 0.28 & 0 & & & & \\
\hline & & & & & & & & & & & & 0.29 & 1 & & & & \\
\hline & & & & & & & & & & & & 0.30 & 0 & & & & \\
\hline & & & & & & & & & & & & $>0.30$ & 77 & & & & \\
\hline
\end{tabular}




\begin{tabular}{|c|c|c|c|c|c|c|c|c|c|c|c|c|c|c|c|c|c|}
\hline \multicolumn{2}{|l|}{$\mathrm{Ba}$} & \multicolumn{2}{|l|}{ La } & \multicolumn{2}{|l|}{$\mathrm{Ce}$} & \multicolumn{2}{|l|}{$\mathbf{R b}$} & \multicolumn{2}{|l|}{ Sr } & \multicolumn{2}{|l|}{$\mathbf{Y}$} & \multicolumn{2}{|l|}{$\operatorname{Zr}$} & \multicolumn{2}{|l|}{$\mathrm{Nb}$} & \multicolumn{2}{|l|}{ Th } \\
\hline Bin & Freq & Bin & Freq & Bin & Freq & Bin & Freq & Bin & Freq & Bin & Freq & Bin & Freq & Bin & Freq & Bin & Freq \\
\hline 0 & 5 & 0 & 0 & 0 & 3 & 0 & 1 & 0 & 16 & 0 & 0 & 0 & 0 & 0 & 6 & 0 & 2 \\
\hline 100 & 146 & 10 & 85 & 10 & 33 & 20 & 68 & 50 & 208 & 5 & 132 & 20 & 87 & 5 & 56 & 5 & 82 \\
\hline 200 & 98 & 20 & 153 & 20 & 49 & 40 & 73 & 100 & 138 & 10 & 179 & 40 & 166 & 10 & 309 & 10 & 304 \\
\hline 300 & 90 & 30 & 215 & 30 & 69 & 60 & 116 & 150 & 118 & 15 & 333 & 60 & 130 & 15 & 364 & 15 & 311 \\
\hline 400 & 65 & 40 & 197 & 40 & 98 & 80 & 181 & 200 & 77 & 20 & 366 & 80 & 110 & 20 & 287 & 20 & 174 \\
\hline 500 & 55 & 50 & 185 & 50 & 121 & 100 & 252 & 250 & 93 & 25 & 229 & 100 & 116 & 25 & 177 & 25 & 117 \\
\hline 600 & 66 & 60 & 114 & 60 & 131 & 120 & 211 & 300 & 101 & 30 & 131 & 120 & 164 & 30 & 86 & 30 & 88 \\
\hline 700 & 66 & 70 & 59 & 70 & 137 & 140 & 209 & 350 & 104 & 35 & 80 & 140 & 163 & 35 & 63 & 35 & 46 \\
\hline 800 & 105 & 80 & 49 & 80 & 115 & 160 & 162 & 400 & 108 & 40 & 41 & 160 & 174 & 40 & 44 & 40 & 24 \\
\hline 900 & 108 & 90 & 24 & 90 & 96 & 180 & 125 & 450 & 115 & 45 & 22 & 180 & 118 & 45 & 31 & 45 & 18 \\
\hline 1000 & 129 & 100 & 17 & 100 & 60 & 200 & 93 & 500 & 111 & 50 & 20 & 200 & 118 & 50 & 20 & 50 & 9 \\
\hline 1100 & 190 & 110 & 6 & 110 & 63 & 220 & 55 & 550 & 124 & 55 & 16 & 220 & 85 & 55 & 13 & 55 & 10 \\
\hline 1200 & 175 & 120 & 3 & 120 & 42 & 240 & 58 & 600 & 108 & 60 & 13 & 240 & 68 & 60 & 5 & 60 & 6 \\
\hline 1300 & 120 & 130 & 2 & 130 & 20 & 260 & 45 & 650 & 108 & 65 & 3 & 260 & 39 & 65 & 3 & 65 & 8 \\
\hline 1400 & 77 & 140 & 3 & 140 & 25 & 280 & 31 & 700 & 86 & 70 & 3 & 280 & 31 & 70 & 2 & 70 & 6 \\
\hline 1500 & 98 & 150 & 1 & 150 & 25 & 300 & 29 & 750 & 52 & 75 & 4 & 300 & 12 & 75 & 1 & 75 & 3 \\
\hline 1600 & 55 & 160 & 1 & 160 & 11 & 320 & 15 & 800 & 51 & 80 & 4 & 320 & 16 & 80 & 4 & 80 & 1 \\
\hline 1700 & 46 & 170 & 1 & 170 & 14 & 340 & 11 & 850 & 38 & 85 & 2 & 340 & 11 & 85 & 3 & 85 & 4 \\
\hline 1800 & 30 & 180 & 2 & 180 & 2 & 360 & 13 & 900 & 18 & 90 & 0 & 360 & 8 & 90 & 2 & 90 & 0 \\
\hline 1900 & 23 & 190 & 2 & 190 & 2 & 380 & 8 & 950 & 18 & 95 & 1 & 380 & 4 & 95 & 4 & 95 & 1 \\
\hline 2000 & 24 & 200 & 0 & 200 & 7 & 400 & 7 & 1000 & 8 & 100 & 2 & 400 & 12 & 100 & 0 & 100 & 1 \\
\hline 2100 & 16 & $>200$ & 2 & 210 & 4 & 420 & 7 & 1050 & 9 & $>100$ & 13 & 420 & 3 & $>100$ & 3 & $>100$ & 5 \\
\hline 2200 & 15 & & & 220 & 2 & 440 & 2 & 1100 & 3 & & & 440 & 2 & & & & \\
\hline 2300 & 10 & & & 230 & 0 & 460 & 4 & 1150 & 5 & & & 460 & 3 & & & & \\
\hline 2400 & 7 & & & 240 & 1 & 480 & 3 & 1200 & 10 & & & 480 & 6 & & & & \\
\hline 2500 & 5 & & & 250 & 0 & 500 & 0 & 1250 & 5 & & & 500 & 1 & & & & \\
\hline 2600 & 5 & & & $>250$ & 14 & $>500$ & 9 & 1300 & 8 & & & $>500$ & 7 & & & & \\
\hline 2700 & 5 & & & & & & & 1350 & 5 & & & & & & & & \\
\hline 2800 & 5 & & & & & & & 1400 & 4 & & & & & & & & \\
\hline 2900 & 5 & & & & & & & 1450 & 1 & & & & & & & & \\
\hline 3000 & 2 & & & & & & & 1500 & 0 & & & & & & & & \\
\hline$>3000$ & 39 & & & & & & & $>1500$ & 5 & & & & & & & & \\
\hline
\end{tabular}


Table 1. Number of observations (Freq) within each composition range (Bin) for north-central and northeast Nevada intrusion database-Continued.

\begin{tabular}{|c|c|c|c|c|c|c|c|c|c|c|c|c|c|c|c|c|c|}
\hline \multicolumn{2}{|l|}{$\mathbf{G a}$} & \multicolumn{2}{|l|}{ Co } & \multicolumn{2}{|l|}{$\mathrm{Cr}$} & \multicolumn{2}{|l|}{$\mathrm{Ni}$} & \multicolumn{2}{|l|}{ Sc } & \multicolumn{2}{|l|}{$\mathbf{v}$} & \multicolumn{2}{|l|}{ Ag } & \multicolumn{2}{|l|}{$\mathrm{Cu}$} & \multicolumn{2}{|l|}{ Mo } \\
\hline Bin & Freq & Bin & Freq & Bin & Freq & Bin & Freq & Bin & Freq & Bin & Freq & Bin & Freq & Bin & Freq & Bin & Freq \\
\hline 0 & 0 & 0 & 10 & 0 & 51 & 0 & 5 & 0 & 2 & 0 & 35 & 0.0 & 1 & 0 & 57 & 0 & 12 \\
\hline 5 & 8 & 5 & 444 & 20 & 461 & 10 & 423 & 5 & 519 & 20 & 327 & 0.2 & 130 & 10 & 566 & 2 & 153 \\
\hline 10 & 52 & 10 & 261 & 40 & 189 & 20 & 162 & 10 & 348 & 40 & 199 & 0.4 & 37 & 20 & 180 & 4 & 114 \\
\hline 15 & 94 & 15 & 106 & 60 & 118 & 30 & 113 & 15 & 109 & 60 & 204 & 0.6 & 19 & 30 & 75 & 6 & 65 \\
\hline 20 & 413 & 20 & 38 & 80 & 87 & 40 & 53 & 20 & 46 & 80 & 173 & 0.8 & 7 & 40 & 70 & 8 & 53 \\
\hline 25 & 189 & 25 & 30 & 100 & 48 & 50 & 21 & 25 & 27 & 100 & 120 & 1.0 & 27 & 50 & 48 & 10 & 17 \\
\hline 30 & 49 & 30 & 33 & 120 & 35 & 60 & 11 & 30 & 13 & 120 & 48 & 1.2 & 7 & 60 & 40 & 12 & 10 \\
\hline 35 & 10 & 35 & 18 & 140 & 32 & 70 & 7 & 35 & 18 & 140 & 36 & 1.4 & 4 & 70 & 27 & 14 & 10 \\
\hline 40 & 1 & 40 & 9 & 160 & 30 & 80 & 15 & 40 & 5 & 160 & 35 & 1.6 & 8 & 80 & 18 & 16 & 8 \\
\hline 45 & 0 & 45 & 11 & 180 & 18 & 90 & 5 & 45 & 3 & 180 & 17 & 1.8 & 3 & 90 & 15 & 18 & 4 \\
\hline 50 & 1 & 50 & 6 & 200 & 26 & 100 & 7 & 50 & 1 & 200 & 17 & 2.0 & 8 & 100 & 16 & 20 & 6 \\
\hline$>50$ & 0 & 55 & 4 & 220 & 29 & 110 & 5 & $>50$ & 2 & 220 & 9 & 2.2 & 6 & 110 & 13 & 22 & 2 \\
\hline & & 60 & 0 & 240 & 11 & 120 & 4 & & & 240 & 8 & 2.4 & 6 & 120 & 5 & 24 & 3 \\
\hline & & $>60$ & 3 & 260 & 7 & 130 & 8 & & & 260 & 10 & 2.6 & 3 & 130 & 5 & 26 & 4 \\
\hline & & & & 280 & 12 & 140 & 5 & & & 280 & 3 & 2.8 & 4 & 140 & 1 & 28 & 4 \\
\hline & & & & 300 & 6 & 150 & 6 & & & 300 & 0 & 3.0 & 4 & 150 & 6 & 30 & 2 \\
\hline & & & & 320 & 9 & 160 & 2 & & & 320 & 2 & 3.2 & 2 & 160 & 5 & $>30$ & 24 \\
\hline & & & & 340 & 6 & 170 & 4 & & & 340 & 5 & 3.4 & 0 & 170 & 3 & & \\
\hline & & & & 360 & 7 & 180 & 0 & & & 360 & 2 & 3.6 & 0 & 180 & 3 & & \\
\hline & & & & 380 & 10 & 190 & 2 & & & 380 & 1 & 3.8 & 2 & 190 & 1 & & \\
\hline & & & & 400 & 4 & 200 & 3 & & & 400 & 1 & 4.0 & 4 & 200 & 2 & & \\
\hline & & & & $>400$ & 39 & $>200$ & 14 & & & $>400$ & 5 & 4.2 & 2 & $>200$ & 84 & & \\
\hline & & & & & & & & & & & & 4.4 & 3 & & & & \\
\hline & & & & & & & & & & & & 4.6 & 0 & & & & \\
\hline & & & & & & & & & & & & 4.8 & 0 & & & & \\
\hline & & & & & & & & & & & & 5.0 & 6 & & & & \\
\hline & & & & & & & & & & & & 5.2 & 2 & & & & \\
\hline & & & & & & & & & & & & 5.4 & 0 & & & & \\
\hline & & & & & & & & & & & & 5.6 & 1 & & & & \\
\hline & & & & & & & & & & & & 5.8 & 0 & & & & \\
\hline & & & & & & & & & & & & 6.0 & 0 & & & & \\
\hline & & & & & & & & & & & & $>6.0$ & 19 & & & & \\
\hline
\end{tabular}




\begin{tabular}{|c|c|c|c|c|c|}
\hline $\mathbf{P b}$ & & $\mathrm{Zn}$ & & $\mathrm{Au}$ & \\
\hline Bin & Freq & Bin & Freq & Bin & Freq \\
\hline 0 & 0 & 0 & 26 & 0.00 & 2 \\
\hline 5 & 46 & 10 & 51 & 0.50 & 88 \\
\hline 10 & 120 & 20 & 116 & 1.00 & 11 \\
\hline 15 & 183 & 30 & 147 & 1.50 & 1 \\
\hline 20 & 199 & 40 & 185 & 2.00 & 6 \\
\hline 25 & 128 & 50 & 201 & 2.50 & 1 \\
\hline 30 & 74 & 60 & 207 & 3.00 & 9 \\
\hline 35 & 52 & 70 & 139 & 3.50 & 1 \\
\hline 40 & 29 & 80 & 121 & 4.00 & 6 \\
\hline 45 & 22 & 90 & 58 & 4.50 & 1 \\
\hline 50 & 14 & 100 & 58 & 5.00 & 14 \\
\hline 55 & 7 & 110 & 28 & 5.50 & 0 \\
\hline 60 & 5 & 120 & 15 & 6.00 & 5 \\
\hline 65 & 3 & 130 & 16 & 6.50 & 1 \\
\hline 70 & 3 & 140 & 11 & 7.00 & 3 \\
\hline 75 & 1 & 150 & 7 & 7.50 & 1 \\
\hline 80 & 5 & 160 & 4 & 8.00 & 4 \\
\hline 85 & 1 & 170 & 11 & 8.50 & 0 \\
\hline 90 & 1 & 180 & 9 & 9.00 & 2 \\
\hline 95 & 1 & 190 & 2 & 9.50 & 0 \\
\hline 100 & 3 & 200 & 1 & 10.00 & 0 \\
\hline 105 & 0 & 210 & 2 & $>10.00$ & 14 \\
\hline 110 & 6 & 220 & 1 & & \\
\hline 115 & 0 & 230 & 0 & & \\
\hline 120 & 1 & 240 & 1 & & \\
\hline 125 & 0 & 250 & 2 & & \\
\hline 130 & 3 & 260 & 0 & & \\
\hline 135 & 0 & 270 & 2 & & \\
\hline 140 & 2 & 280 & 0 & & \\
\hline 145 & 0 & 290 & 0 & & \\
\hline 150 & 3 & 300 & 1 & & \\
\hline$>150$ & 16 & $>300$ & 23 & & \\
\hline
\end{tabular}

